AUREG/GR-1301

PNL-3275

\title{
Analysis of Organohalogen Products From Chlorination of Natural Waters Under Simulated Biofouling Control Conditions
}

Prepared by R.M. Bean, D.C. Mann, R.G. Riley

Pacific Northwest Laboratory

Operated by

Battelle Memorial Institute

Prepared for

U.S. Nuclear Regulatory

Commission 


\section{NOTICE}

This report was prepared as an account of work sponsored by an agency of the United States Government. Neither the United States Government nor any agency thereof, or any of their employees, makes any warranty, expressed or implied, or assumes any legal liability or responsibility for any third party's use, or the results of such use, of any information, apparatus product or process disclosed in this report, or represents that its use by such third party would not infringe privately owned rights.

\section{Available from}

\section{GPO Sales Program}

Division of Technical Information and Document Control

U. S. Nuclear Regulatory Commission Washington, D. C. 20555

Printed copy price: $\$ 4.25$

and

National Technical Information Service Springfield, Virginia 22161 


\section{Analysis of Organohalogen Products From Chlorination of Natural Waters Under Simulated Biofouling Control Conditions}

Manuscript Completed: May 1980

Date Published: June 1980

Prepared by R.M. Bean, D.C. Mann, P.G. Riley

Pacific Northwest Laboratory

P.O. Box 999

Richland, WA 99352

Prepared for Division of Saieguards, Fuel Cycle and Environmental Research Office of Nuclear Regulatory Research U.S. Nuclear Regulatory Commission Washington, D.C. 20555

NRC FIN No. B2098 



\section{ABSTRACT}

The products of low-level chlorination of natural waters from ten locations across the continental United States have been studied, with emphas is on volatile and lipophilic organohalogen components. A specially designed apparatus permitted continuous sampling and chlorination of water in a manner analogous to some types of cooling water treatments. Volatile components were analyzed using headspace, purge-and-trap, and resin adsorption methods. The less-volatile components were collected by passing large volumes of the chlorinated water over XAD-2 columns. Total organic halogen collected on XAD resins was compared with the halogen contribution of haloform compounds. The XAD samples were further separated into fractions according to molecular weight and polarity using liquid chromatography. These studies indicate that haloforms are the most abundant lipophilic halogenated products formed from low-level chlorination of natural waters, but that other halogenated lipophilic material is also formed. 



\section{SUMMARY}

Although much knowledge has recently been developed about the formation of organohalogen compounds during chlorination of natural waters, little information has been presented which compares the organohalogen production from low-level chlorination of water bodies differing widely in physical and chemical properties.

In order to develop information concerning the range of organohalogen products to be expected from low-level chlorination for biofouling control in electric power plants, we have investigated the organohalogen products arising from chlorination of natural waters at 10 Tocations in the continental United States. This work is part of an interdisciplinary program to study the chemistry and aquatic toxicology associated with current cooling water treatment practices at nuclear power stations.

Sampling was conducted at ten locations within the continental United States, representing water from the Columbia River (WA), Ohio River (WV), Lake Michigan (MI), Missouri River (MO), Tennessee River (KY), Cape Fear (NC), Lake ivorman (NC), Connecticut River (CT), Pacific Ocean at San Onofre (CA), and Sequim Bay (WA).

Approximate1y 200 liters of water were sampled at each station using the XAD-2 method. Chlorine was added in concentrations ranging from 2.7 to $5.7 \mathrm{mg} / \ell$. Control water was prepared and sampled identically to the chlorinated water with the exception of the added chlorine. In addition to the XAD samples, samples were obtained from both control and chlorinated water for analysis of volatile organohalogen components by both headspace and purge-and-trap techniques.

The results of analysis for haloforms showed that chloroform was a major product from fresh water chlorination and bromoform was a major product from salt water chlorination. There was wide variation in both amounts and types of haloforms found at the different stations. Ion chromatographic analys is of the water from five fresh water locations for bromide jon showed a general correspondence between levels of bromide ion and appearance of brominated haloforms. In addition to the haloforms, samples were examined for 16 halogenated compounds which are also on the EPA list of toxic chemicals. Dichloromethane and $\mathrm{di}$ - and trichloroethylene were identified at several locations in $\mu \mathrm{g} / \ell$ concentrations, but no evidence was found to 1 ink the presence of these compounds with the chlorination, since in general, they were also found in controls.

Analysis of samples collected on XAD-2 resin columns indicates that the amount of chlorine going toward production of lipophilic nonhaloform halogenated material less than $800 \mathrm{MH}$ is from about 0.5 to as much as $10 \mathrm{\mu g} / \mathrm{h}$, but that in every case is substantially less than that going to haloform.

A] though a number of chlorinated aromatic hydrocarbons were detected in chlorinated samples with the use of gas chromatography/mass spectrometry, they were usually also found in the control samples. Dichlorobenzene was 
found in most samples. Many samples indicate the presence of pesticides and PCBs. Although the electron capturing activity of the chlorinated samples was generally much greater than the nonchlorinated control, examination of the mass spectra corresponding to electron capture peaks usually did not reveal halogen isotope ratios. Low concentrations of chlorinated phenols were detected at several of the locations studied. No phenols were found in controls. Electron capture data suggests that they are present in less than $\mu \mathrm{g} / \ell$ concentrations. 
Abstract . . . . . . . .

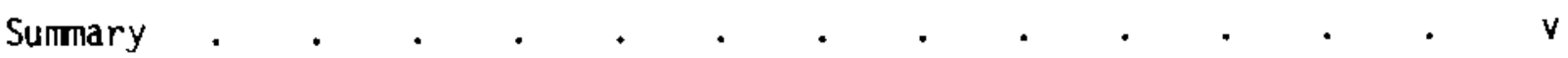

List of Figures . . . . . . . . . . . . . . . . . ix

List of Tables .

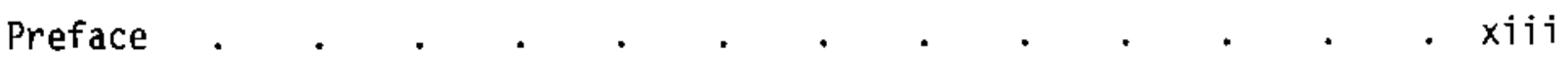

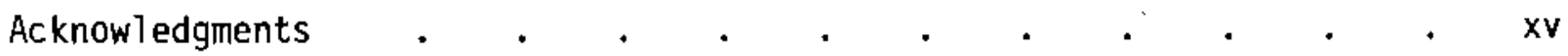

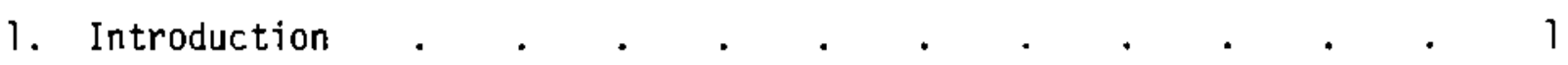

2. Sampling Chlorinated Natural Waters at Ten U.S. Locations . . 3

2.1 High-Volume Sampling with XAD-2 Resins . . . . . 3

2.2 Sampling Locations, Procedures, and Inventory . • • • • 4

3. Analytical Procedures . . . . . . . . . . . . . 9

3.1 Analysis of Volatile Organics . . . . . . . . . . 9

3.2 Procedures for Extraction, Separation, and Analys is of XAD Samples . . . . . . . . . . . 12

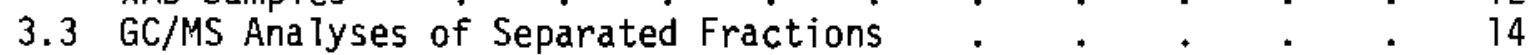

3.4 Analysis of River and Sea Waters for $\mathrm{Br}$ and $\mathrm{Cl}$ by
Ion Chromatography $. \quad . \quad . \quad . \quad . \quad . \quad . \quad . \quad . \quad 15$

4. Evaluation/Validation of Quantitative Methods. . . . . . 17

4.1 Volatiles Analyses . . . . . . . . . 17

4.2 XAD-2 Samples: Procedural Recoveries from Separation Scheme . 21

4.3 Haloform Analysis of XAD-2 Extracts . . . . . . . 24

4.4 Total Organic Halogen by Microcoulometry . $\quad . \quad$. $\quad . \quad 25$

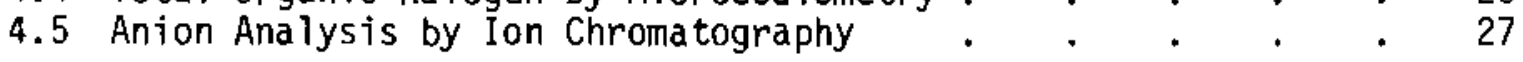

5. Analysis of Chlorinated Natural Waters: Results and Discussion . 29

5.1 Volatile Components . . . . . . . . . . 29

5.2 XAD-2 Samples: Haloforms and Organic Halogen Analyses : $\quad 33$

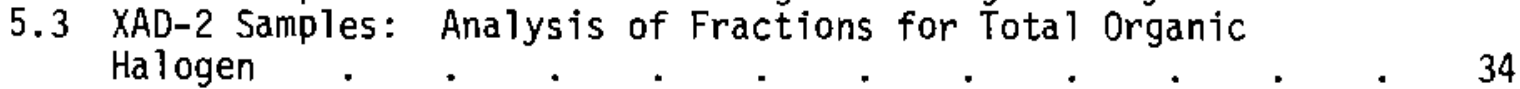

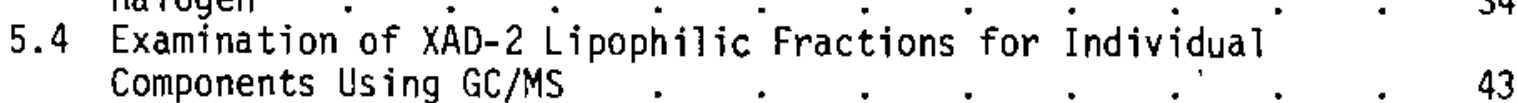

5.5 Examination of XAD-2 Carbonate Extracts for Phenols . . 47 
6. Conclusions and Recommendations . . . . . . . . 53

References . . . . . . . . . . . . . 55

Appendixes
A. Sample Inventory from Ten U.S. Locations
B. Preliminary Data on Columbia River and Sequim Bay XAD-2 Extracts
C. GC/MS Spectra from Ether Extracts
D. GC/MS Spectra from Phenol Extracts

$:$ :

$\begin{array}{ll}\cdot & A-1 \\ \cdot \quad & 8-1 \\ \cdot \quad & D-1\end{array}$




\section{LIST DF FIGURES}

1. Schematic of Apparatus of Field Sampling for Chlorinated Natural Waters. . . . . . . . . . . 4

2. Location of Sampling Stations . . . . . . . . . 5

3. Schematic of Purge and Trap Methodology . . . . . . 9

4. Total Ionization Chromatogram of Purge and Trap Standards Mixture "A" . . . . . . . . . . . 11

5. Total Ionization Chromatogram of Purge and Trap Standards
Mixture "B" . . . . . . 11

6. Separation Scheme for Chlorinated Water Sampled by XAD-2

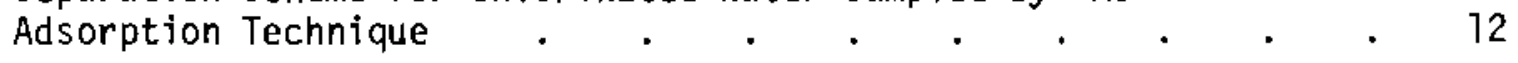

7. Gas Chromatogram of Ether Extract . . . . . . . 14

8. Calibration Curve for Purge and Trap Technique . . . . 18

9. Calibration Curve for $\mathrm{CHCl}_{3}$ Using the Headspace Method . . . 19

1D. Relative Response Factors for Electron Capture Analys is of XAD-2 Extracts . . . . . . . . . . 25

11. Total Ionization Chromatogram Obtained from Lipophilic Fraction of XAD-2 Extract of Chlorinated Tennessee River Water

12. Electron Capture Chromatogram Corresponding to the Total Ionization Scan in Figure $11 . . \quad . \quad . \quad$.

13. Background Subtracted Spectra of Component Found at RT $=19.6$ Using Chromatograms Shown in Figure 13, Showing Principle Fragmentation Ions for Monochlorophenol . . 48

14. Ion Chromatograms from Chlorinated Connecticut River Phenol Sample 



\section{LIST OF TABLES}

1. Chloroform Headspace Analysis: Freshwater Low-Level

Chlorination Experiment with SaTmonids . . . . . . 20

2. Comparison of Bromoform Analyses at Three Seawater

Stations. . . . . . . . . . . 20

3. Comparison of Methods of Haloform Analyses of Chlorinated
Waters . . . . . 21

4. Procedural Recoveries--Ether Evaporation . . . . . 22

5. Procedural Recoveries--Gel Permeation Chromatography . . . 22

6. Procedural Recoveries--Silica Gel Chromatography . . . . 23

7. Overall Procedural Recoveries . . . . . . . . 23

8. Reproducibility of Microcoulometric Method for Total

Organic Chlorine in XAD-2 Samples . . . . . . . 26

9. Concentrations of Volatile Organics in Natural Waters as

10. Comparison of Chloroform Analyses by Purge and Trap

Technique with Headspace Technique . . . . . . . 31

11. Anionic Species Present in River and Sea Water Samples. . . 32

12. Comparison of Haloform Content in XAD-2 Extracts with

Total Organic Halogen . . . . . . . . . 36

13. Analysis of $X A D-2$ Extracts and Fractions for Tota 1

Organic Halogen . . . . . . . . . . . 38

14. Halogen Recovery in Organic Fractions Expressed as
$\mu \mathrm{g} / \mathrm{l}$ Chlorine. . . . . 40

15. Halogen Recovery from XAD-2 Columns in Series Expressed

16. Phenols Identified in Chlorinated Water Samples . . . . 49 



\section{PREFACE}

This report includes data and analysis for the Analytical Chemistry Task of the program on Biocide By-Products in Aquatic Environments.

Reports prepared for the entire program are:

Title

- Investigation of Halogenated Components Formed from ChTorination of Natural Waters: Preliminary Studies, NUREG/CR-I299

- Acute Toxicity and Bioaccumulation of Chloroform to Four Species of Fresh Water Fish Salmo gairdneri, Rainbow Trout Lepomis macrochirus, Bluegill Micropterus salmoides, Largemouth Bass Ictalurus punctatus, Channel Catfish, NUREG/CR-0893

- Chronic Effects of Chiorination By-Products on Rainbow Trout, Salmo gairdneri, NUREG/CR-0892

- Toxicity, Bioaccumulation and Depuration of Bromoform in Five Marine Species Protothaca staminea, Littleneck Clam Mercenaria mercenaria, Eastern Hard Clam, Quahog Crassostrea virginica, Eastern oyster Penaeus aztecus, Brown Shrimp Brevoortia tyrannus, Atlantic Menhaden, NUREG/CR-1297

- Growth and Histological Effects to Protothaca staminea, (Littleneck Clam) of Long-Term Exposure to Chiorinated Sea Water, NUREG/CR-1298

- Analysis of Organohalogen Products from Chlorination of Natural Waters Under Simulated Biofouling Control Conditions, NUREG/CR-1301

- Biocide By-Products in Aquatic Environments, Fina 1 Report Covering Period September 10, 1976 through September 30,1979 , NUREG/CR-1300
Author

Roger M. Bean Robert G. Riley

David R. Anderson E. William Lusty

David R. Anderson Roger M. Bean Roger E. Schirmer

Charles I. Gibson Fredrick C. Tone Peter Wilkinson 3. W. Blaylock Roger E. Schirmer

Charles 1. Gibson Robert E. Hillman Peter Wilkinson Dana L. Woodruff

Roger M. Bean Da le C. Mann Robert G. Riley

Roger M. Bean Charles I. Gibson David R. Anderson 



\section{ACKNOWLEDGMENTS}

This work was performed for the U.S. Nuclear Regulatory Commission (NRC) under a Related Services Agreement with the U.S. Department of Energy Contract DE-AC06-76RL0-1830. The author wishes to acknowledge the guidance and assistance provided by Dr. Phillip R. Reed of NRC.

Contributors to this report are:
R. M. Bean
Principal Investigator, Staff Scientist
D. C. Mann Scientist
K. M. McFadden
Scientist
R. G. Riley
Senior Research Scientist
B. W. Wilson Senior Research Scientist
E. W. Lusty Specialist
T. 0 . Thatcher Consultant

Trade names and registered trademarks are used to assist the reader in replicating the experiments. Their use does not constitute endorsement by Battelle Memorial Institute or the U.S. NRC. 



\section{INTRODUCTION}

The potential problems of chlorine in aquatic environments have been recognized for several years. Brungs (1973) pointed out the potential effects of chlorine residual on aquatic life. Rook (1974) studied the formation of haloforms during chlorination of natural waters, and Dowty et al. (1975) demonstrated a large number of volatile chlorinated organics to be present in both treated and untreated New Orleans municipal water. Subsequent7y, the ubiquitous presence of volatile organic chlorinated chemicals in chorine-treated waters was demonstrated through a national survey of drinking water (Symons et al., 1975).

In view of these findings, it was natural to address the possibility of a similar formation of chloroorganics from biofouling treatment of power plant cooling water. An authoratative estimate (Hamilton, 1978) of the annual quantity of chlorine used in cooling water in United States electricity generating plants is 26,000 tons. Jolley (1977) pointed out the potential for formation of haloorganics from the treatment of cooling waters, and shortly thereafter several workers (Jolley, 1978; Bean et a1, 1978; and Carpenter and Smi th, 1978) reported on studies related to the formation of halogenated compounds from the low level chlorination of natural waters. Studies of this type assume additional importance in view of the work of Davis, et a7. (1977), which describes distinct biological responses to chlorination at levels below chemical detectability.

The study reported here is an integral part of a comprehensive program to investigate the formation of organohalogen compounds through chlorination of fresh and marine waters, and to determine the toxicity and effects of the chiorinated water on aquatic organisms. The reports resulting from the overall program are listed in the front of this document. The chemistry studies described in this document have the following objectives.

- To apply we11-documented procedures for sampling, separation, and trace anatysis of organohalogen compounds formed from the low-level chlorination of fresh and marine waters.

- To use these methods to study the organic chlorination chemistry of a number of natural water bodies which are actual or potential receiving waters for chlorinated electric power plant cooling water.

- To document the extent to which addition of chlorine to these water bodies results in the formation of lipophilic organohalogen components having the potential for bioaccumulation or biomagnification.

- To determine the extent of formation of other volatile and toxic lower molecular weight halogenated organics; specifically the haloforms and phenols.

In order to accomplish these objectives it was necessary to construct a portable apparatus for the continuous low-level chlorination of natural waters, and to sample and analyze the chlorinated water in a manner consistent with the objectives. Although humic acids from natural waters have been shown to react with chlorine (0liver, 1978), these materials were not considered in our sampling 
and analytical scheme because of their relatively low potential for immediate aquatic toxicity or bioaccumulation. The method selected for sampiing and concentrating lipophilic halogenated organics is the very well documented XAD resin adsorption technique. The method has been exhaustively studied (Junk et a1., 1974, 1976) from the points of view of technique, resin purity, and efficiency of recovery of a wide variety of compound types. The technique has been applied extensively to studies of haloorganics in treated wastewater (Glaze, et a1. 1975a, 1975b, 1976, 1977). An extensive review of the technique has been published recently by Dressler (1979).

The use of these columns precluded the concentration of organics with relatively reactive chlorine-nitrogen bonds, such as the chloramines, since prior to column adsorption, destruction of active chlorine with sodium sulfite was necessary to avoid additional chlorination reactions with the material trapped on the column (Bean, 1978; Glaze, 1977).

The analysis of lipophilic halogen compounds adsorbed on the XAD-2 resin using microcoulometry to determine the total organic chlorine in the adsorbed material is based on the work of Glaze et a]. (1977), who suggested that non-haloform organic halogen trapped on XAD-2 resin was an important water quality parameter. Although we adapted the general strategy of determining organic halogen, we also subjected the material to further separation steps in order to classify the type of material adsorbed according to molecular weight and polarity.

The analysis of volatile organics in the chlorinated and control waters was accomplished using both "headspace" (Bush et al., 1977) and "purge-and-trap" methods (Bellar and Lichtenberg, 1974). Methods of this general type have been reviewed recently by Drozd and Novak (1979).

Halogenated phenols are not necessariiy considered lipophiles since they do not adsorb well on XAD-2 at neutral or basic pH (Junk et a1., 1974). However, we chose to add phenols to our analytical scheme because they are a chemical class which is likely to be formed from the chlorination of natural waters. Rook (1977) pointed out the possibility of halophenol formation from humate substances in natural waters. Shimizu and Hsu (1975) have reported on the conversion of plant phenylpropaniods to chlorophenolic derivatives with aqueous chlorine. In addition, phenols have been shown by Carlson, et al (1975) to be many times more reactive to aqueous chlorine than the corresponding hydrocarbon. Therefore, we have adapted a procedure from Krijgsman and Van de Camp (1977) for the isolation and determination of phenols from XAD-2 adsorption coiumns.

Substantial effort has been made during the course of this program to document the methods used with respect to reproduceability, reliability, and efficiency of recovery. A section of this report discusses these aspects of the work. The observations made and conclusions drawn from the reported data are only as good as the confidence in the data. Because of the complexity of the research problem and the very low concentrations of chlorinated materials in most of the samples studied in this program we have made an attempt to interpret our results in the context of the quality of the data generated. 
2. SAMPLING CHLORINATED NATURAL WATERS AT TEN U.S. LOCATIONS

\subsection{High-Volume Sampling with XAD-2 Resins}

In our initial experiments with XAD-2 sampling (Bean, et al., 1980) we did not destroy active halogen prior to sampling. Analysis of these samples demonstrated that there was chemical interaction between the active halogen and the XAD- 2 resin which resulted in the formation of halogenated artifacts. Continuous passage of active chlorine through the sampling column can also result in additional chlorination of material adsorbed from the water, and possible destruction of some compounds by chemical oxidation. Glaze et al. (1977) reports that chlorophenols are not recoverable unless the active chlorine is destroyed prior to adsorption. Suffett (1976) used continuous addition of $\mathrm{Na}_{2} \mathrm{SO}_{3}$ to collect chlorinated organics from drinking water supplies. He also adjusted the $\mathrm{pH}$ to 4 , presumably to prevent base-catalyzed hydrolysis and substitution reactions. The sampling method adopted for this work includes destruction of active chlorine with a fivefold excess of $\mathrm{Na}_{2} \mathrm{SO}_{3}$ as well as continuous adjustment of $\mathrm{pH}$ to 4.5 using an automatic $\mathrm{pH}$ controller. An acidic condition is required to insure recovery of acids and phenols (Junk et al., 1974). The XA0-2 resin used for sampling is cleaned by the method of Junk et al. (1974) and packed into $2.55 \times 23 \mathrm{~cm}$ stainless steel columns. The volume of XAD-2 resin used is $82 \mathrm{ml}$, with a cross-sectional area of $3.98 \mathrm{~cm}^{2}$. This permits pumping rates up to $160 \mathrm{ml} / \mathrm{min}$. Normally, several hundred $1 \mathrm{iters}$ of chlorinated water are passed through a resin column to obtain a sample.

For our field sampling program, portable equipment has been constructed which continuously pumps water from the natural environment and treats it with from 2 to 5 parts-per-million chlorine as NaOCl (ACS Analytical Reagent Grade). A schematic of the apparatus is shown in Figure 1. A baffled chlorine contact chamber allows a residence time of about an hour before the chlorinated water is treated with $\mathrm{Na}_{2} \mathrm{SO}_{3}$ and brought to a pH of $n_{4} .5$ with reagent grade $\mathrm{H}_{2} \mathrm{SO}_{4}$ by an automatic $\mathrm{pH}$ controller. Total residual chlorine in the water was measured with a Fisher Porter Model 1711010 amperometric titration system. The treated water is then pumped through the XAD-2 column using a positive displacement pump. Because most water sources contain trace chlorinated compounds, all reagents and water are self-contained within the apparatus. On occasion, when acid demand has been heavy, the natural water source has been used to prepare the sulfuric acid solution. For transport, the components of the sampling apparatus are fitted into a fiberglass container which also can accommodate tools, spare parts, and containers required for samples. 0imensions are 0.50 $\times 0.64 \times 1.40$ meters; shipping weight is about $90 \mathrm{~kg}$. Two identical devices are used, one for the chlorinated samples and one to simultaneously sample unchlorinated water as a control. To minimize contamination of water samples by the sampling apparatus, the only materials in contact with the sample are polypropylene, teflon, ceramic, and stainless steel. The plastic parts, including the fiberglass containers, were immersed in flowing river water for several days before use, to minimize leachable impurities. 


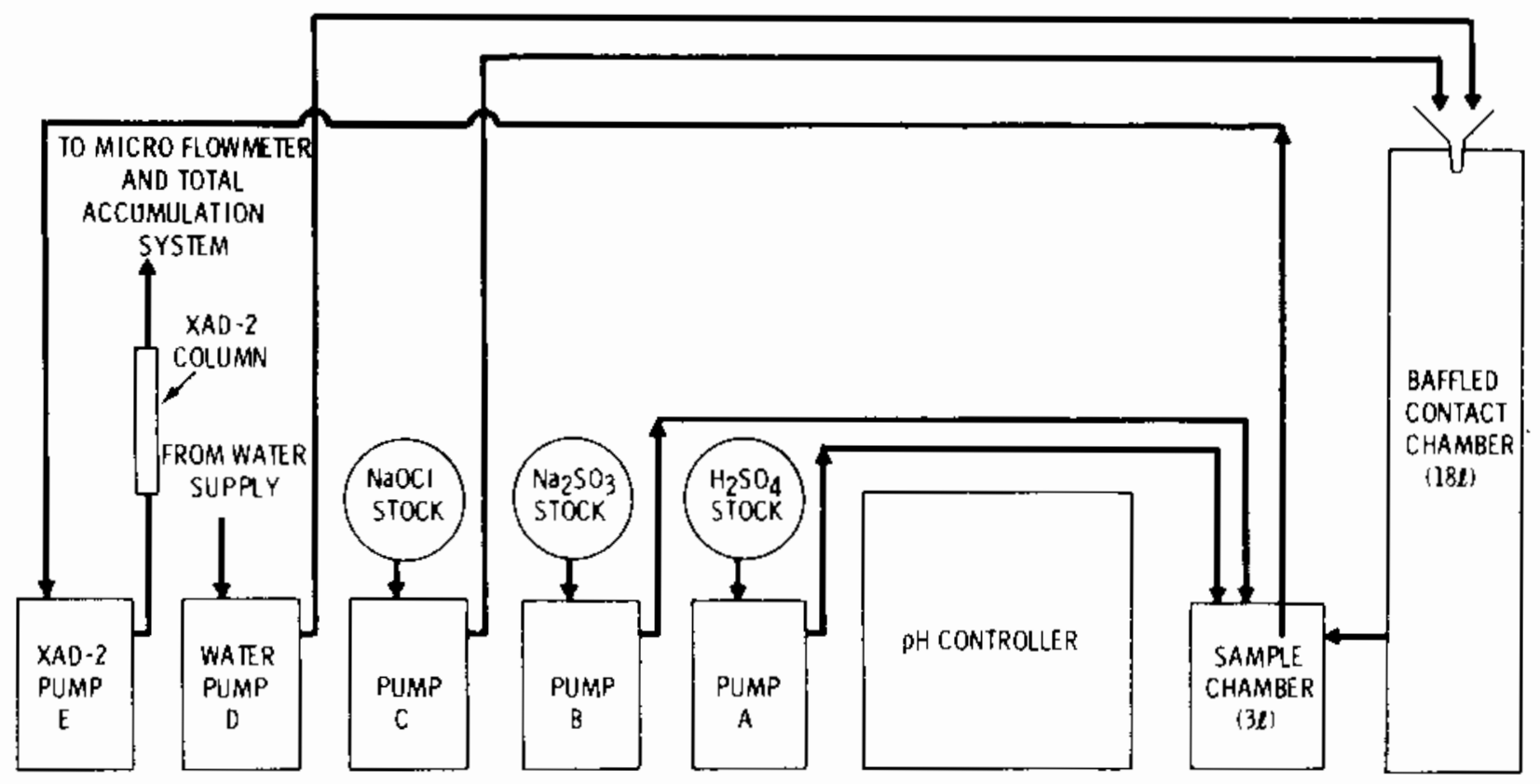

PUMP A - TUBING PUMP (FLOW RATE $006-2280 \mathrm{~m} \ell / \min$ )

PUMP B $\}$ MINI PUMP

PUMP C $\int$ IFLOW RATE 0.7-70 mlthour'

PUMP D POSITIVE DISPLACEMENT PUMP

PUMPE $\int$ (FLOW RATE 0-450 meimin - pressures to 100 psigl

\section{FIGURE 1. Schematic of Apparatus for Field Sampling of} Chlorinated Natural Waters

\subsection{Sampling Locations, Procedures, and Inventory}

The equipment and procedures described above were used to sample ten water bodies in the United States. Sample locations were shown in Figure 2. A complete listing of samples is given in Appendix Table A-1. High volume XAD-2 samples were collected as follows: Two XAD-2 columns were connected in series for all samplings. One set of two columns was used to sample the unchlorinated control water. For the chlorinated sample, two sets of columns in series were used simultaneously by inserting a tee after the positive displacement pump. Thus we collected two control columns (top and bottom) and four chlorination columns (two top and two bottom). The exception to this sampling regimen was Station \#2, at Sequim Bay, WA. This station was used as a preliminary field trial location for our XAD-2 sampling technique. The number of XAD-2 samples taken were fewer, and no samples were taken for volatiles at this location.

Other types of water samples were taken at the sampling stations for analyses by methods for which the high volume samples are not appropriate. 
- Purge-and-Trap Samples--A $125 \mathrm{me}$ glass bottle was filled to overflowing with water from the sample chambers (after $\mathrm{Na}_{2} \mathrm{SO}_{3}$ and acid had been added). The bottle was sealed with a Hycar septum. Duplicates were taken of chlorinated and unchlorinated water. These samples were analyzed for volatile components using the purge-and-trap technique of Bellar and Lichtenberg (1974).

- Headspace Samples--To a 125 me glass bottle containing $5 \mathrm{~g} \mathrm{NaCl}$ and ح200 $\mathrm{mg} \mathrm{Na} \mathrm{SO}_{3}, 15 \mathrm{ml}$ water was added from the chlorine contact chamber. These samples were normally taken in triplicate from both chlorinated and unchlorinated sampling systems. These samples were analyzed for haloform according to the method of Bush et al. (1977). See Section 3 for procedures.

- Bulk Samples--Approximately 5 liters of untreated water were sampled in bulk as a contingency sample.

A11 samples were kept at wet ice temperature in the field until received at the Richland Laboratories with the exception of the bulk water samples which were frozen as soon after sampling as practicable. XAD-2 samples and samples for volatiles analysis were kept at $4^{\circ} \mathrm{C}$ in the laboratory until analyzed.
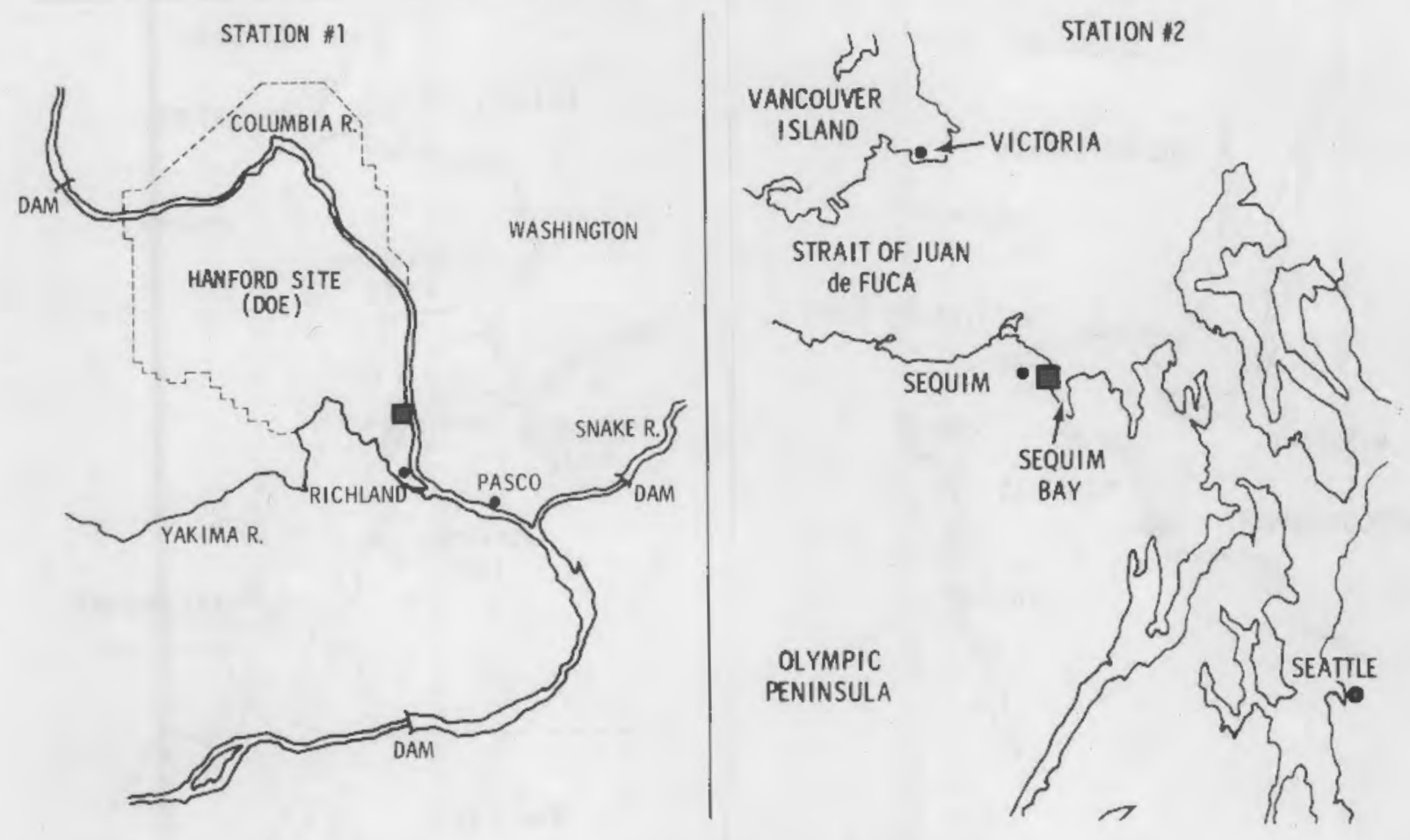

FIGURE 2. Location of Sampling Stations ( $\mathbf{a}$ ) 


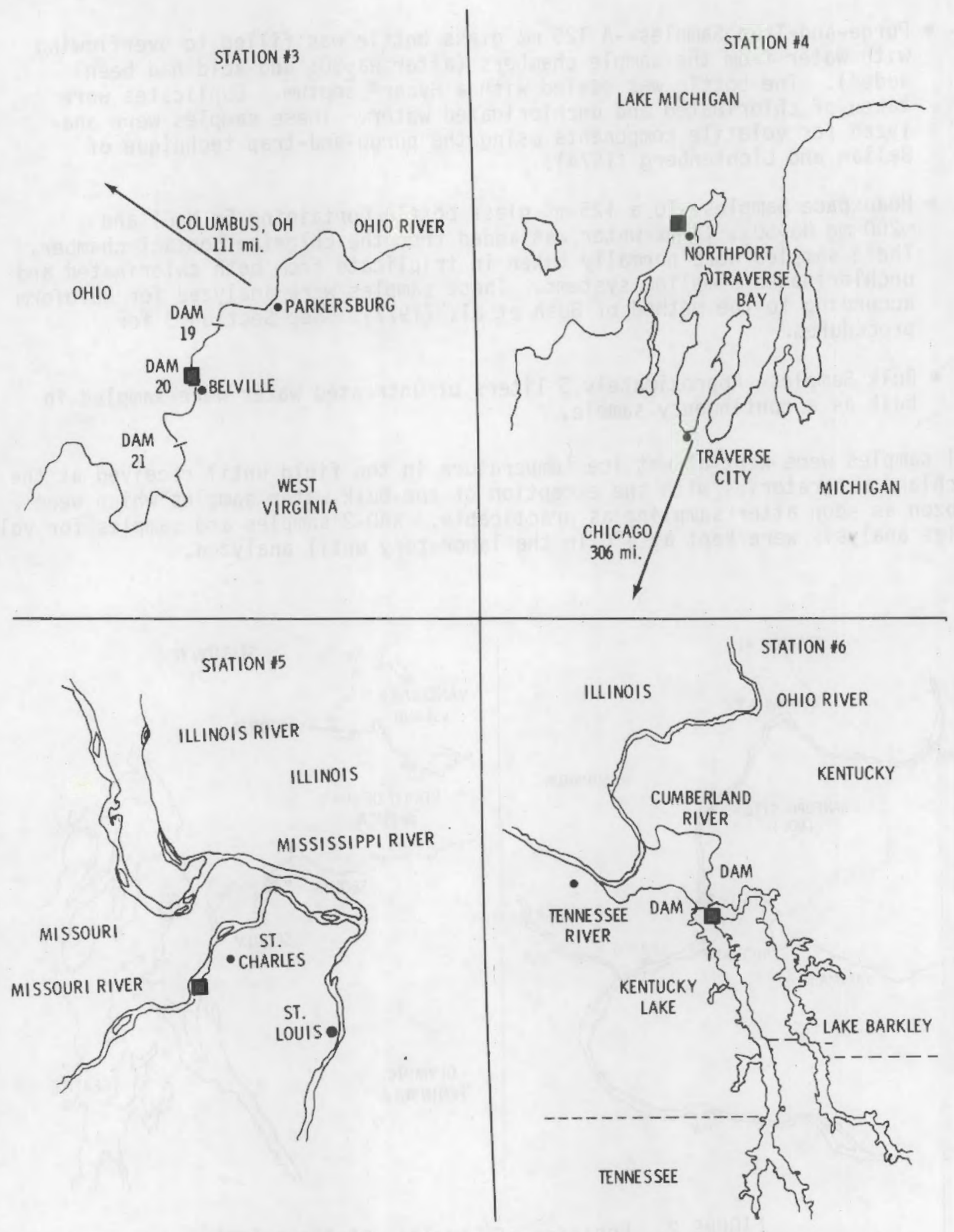

FIGURE 2. Location of Sampling Stations ( $)$ (contd) 


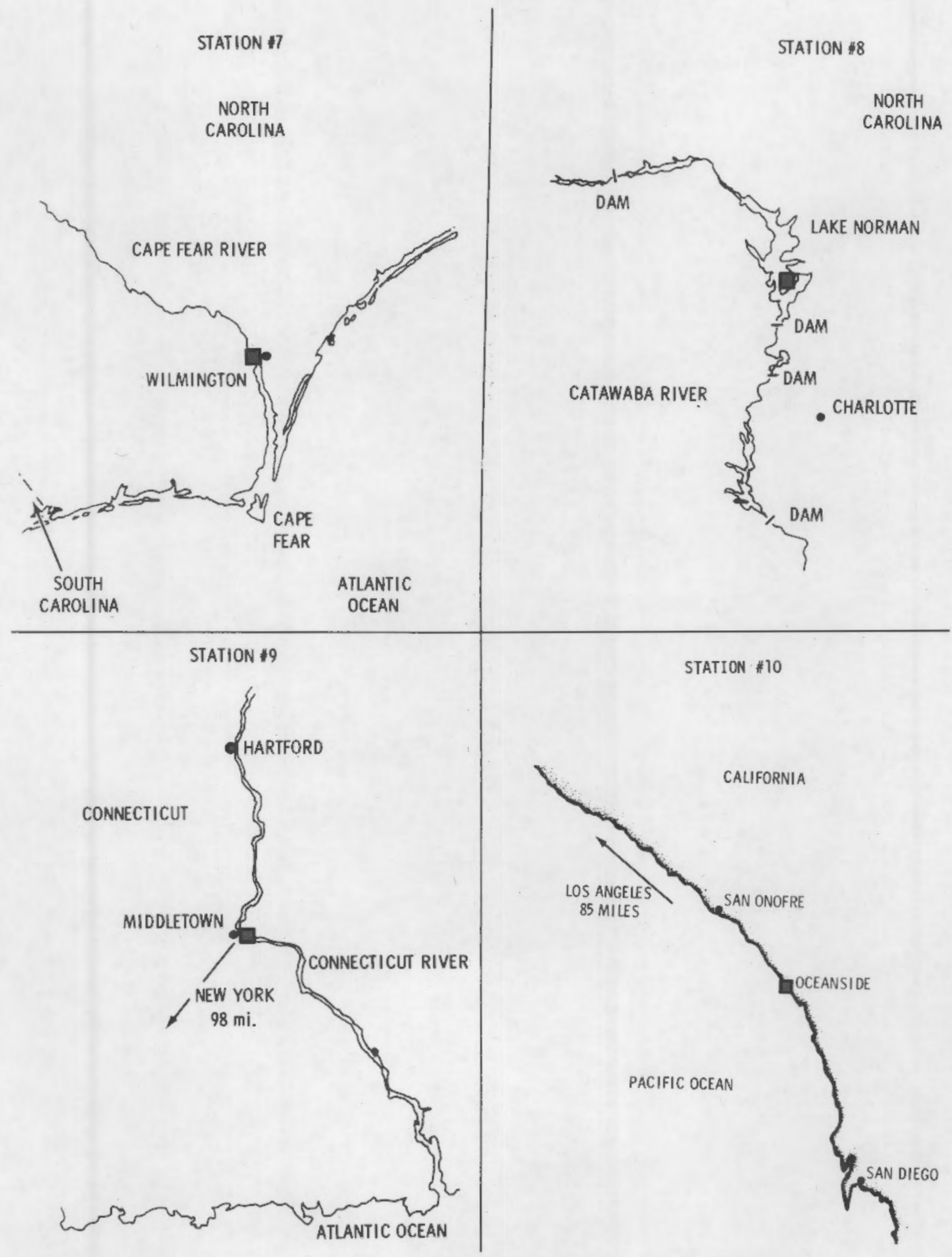

FIGURE 2. Location of Sampling Stations ( $\square$ ) (contd) 



\section{ANALYTICAL PROCEDURES}

\subsection{Analys is of Volatile Organics}

\subsubsection{Purge and Trap Technique}

The procedure used for this analysis is similar to that discussed by Bellar and Lichtenberg (1974). A sample of water containing the volatile organics was sparged with nitrogen gas and then passed through a stainless steel column packed with porous polymer beads (in this case, Tenax. ${ }^{*}$ ). Volatile organics, which are adsorbed on the polymer, are then introduced into the gas chromatograph/mass spectrometer (GS/MS) by heating the Tenax trap at about $200^{\circ} \mathrm{C}$ in a stream of helium. The steps of the procedure are illustrated in Figure 3. This process desorbs the organics from the polymer beads and adsorbs them on to the front of the chromatographic column held at $0^{\circ} \mathrm{C}$. After the volatiles have been introduced onto the column, they are separated by conventional temperature-programmed gas chromatography. (a)

(a) The porous polymer traps, sparging apparatus, GC adapters, and column heater are available from Envirotest Equipment Company as part of a Trace Organic Concentrator Kit.

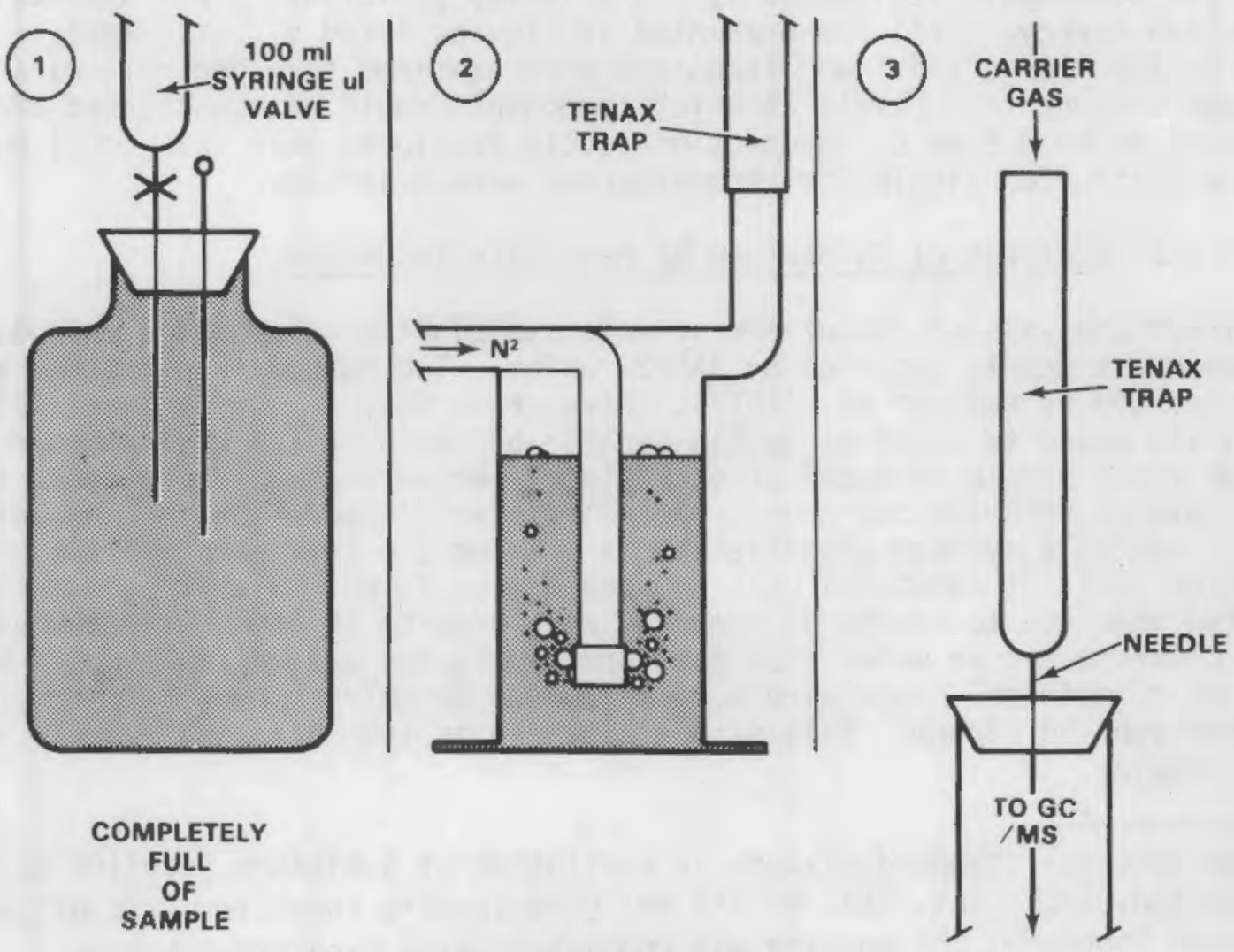

FIGURE 3. Schematic of Purge-and-Trap Methodology 
1 important part of the procedure is the prevention of water sample exposure to an air interface prior to sparging, since the volatiles are rapidly lost to air. To avoid this loss, two hypodermic needles were inserted through the sample bottle septum (Fig. 3); one of which was attached to a $100 \mathrm{ml}$ glass syringe fitted with a stopcock valve. About 80 me of water sample was then carefully drawn into the syringe and the valve closed. Thirty-five milliliters of sample was expressed from the syringe into the sparging appartus through a small-bore teflon tube, filling the apparatus from the bottom up. The remainder of the sample was stored in the syringe as a contingency sample. Just prior to sparging, one microliter of the ethanolic solution of internal standard mixture containing $0.8 \mathrm{mg} / \mathrm{l}$ each of bromochloromethane (Int. Std. \#1), 1, 4-dichlorobutane (Int. Std. \#2) and 1-chloro-2-bromopropane (Int. Std. \#3)(a) was added. Nitrogen purge of the sample was at $30 \mathrm{ml} / \mathrm{min}$ for 20 minutes.

Separation of volatile components was accomplished on a $2 \mathrm{~mm}$ ID glass $6-\mathrm{ft}$ column packed with $0.2 \%$ Carbowax 1500 on Carbopack, using $20 \mathrm{ml} / \mathrm{min}^{\otimes}$ helium carrier. After an initial hold at $0^{\circ} \mathrm{C}$ for sample introduction $(5.5 \mathrm{~min})$, the chromatographic oven was brought to $45^{\circ} \mathrm{C}$ in $1.5 \mathrm{~min}$ and then programmed at $8^{\circ} \mathrm{C} / \mathrm{min}$ to $160^{\circ} \mathrm{C}$. Instrumentation was a Hewlett-Packard Model $5985 \mathrm{GC} / \mathrm{MS}$ System, including a Model $5840 \mathrm{~A}$ Gas Chromatograph. Mass spectra were obtained by scanning in the electron impact mode from mass 45 to 320 at $180 \mathrm{amu} / \mathrm{sec}$.

Total ionization chromatograms of two sets of analytical standards containing 23 of the components designated as EPA priority pollutants (Environmental Protection Agency, 1977) are presented in Figures 4 and 5. A11 samples analyzed by the "Purge and Trap" technique were examined for spectra indicative of these components. Levels at which components could be quantitated are estimated to be $0.5 \mathrm{mg} / \mathrm{l}$. Dectection levels are lower than this $(<0.1 \mathrm{mg} / 1)$ when reconstructed single ion chromatograms were examined.

\subsubsection{Analysis of Chloroform by Headspace Technique}

For direct analysis of chloroform in water we adapted a headspace method, since chloroform is poorly adsorbed on XAD-2 resins. The method is patterned after that reported by Bush et a1. (1977). Five grams $\mathrm{NaCl}$ and approximately $200 \mathrm{mg}$ $\mathrm{Na}_{2} \mathrm{SO}_{3}$ are added to a 125 me bottle capable of being sealed with a Hycar septum. A 15 me water sample is added, the bottle is sealed and partly immersed in a water bath at $99^{\circ} \mathrm{C}$ for one hour. One milliliter of headspace is subsampled using a sealable syringe and injected onto a $2 \mathrm{~mm} \times 6-\mathrm{ft}$ Chromasorb 101 column. Detection limit is about $0.1 \mu \mathrm{g} / \mathrm{l}$. Quantitation is established by comparing the area obtained to standards prepared according to the following procedures: $15 \mathrm{me}$ chloroform-free water plus salt and $\mathrm{Na}_{2} \mathrm{SO}_{3}$ are sealed in a sample bottle and $3 \mu l$ of methanol containing a known amount of chloroform is added by injection through the septum. This standard sample is then analyzed exactly as the other samples.

(a) The internal standard mixture is a dilution of a mixture supplied by Supelco, Inc. Int. Std. \#3 did not give spectra characteristic of the bromo compound; the spectra was consistent with 2-chloro-2-butene. 


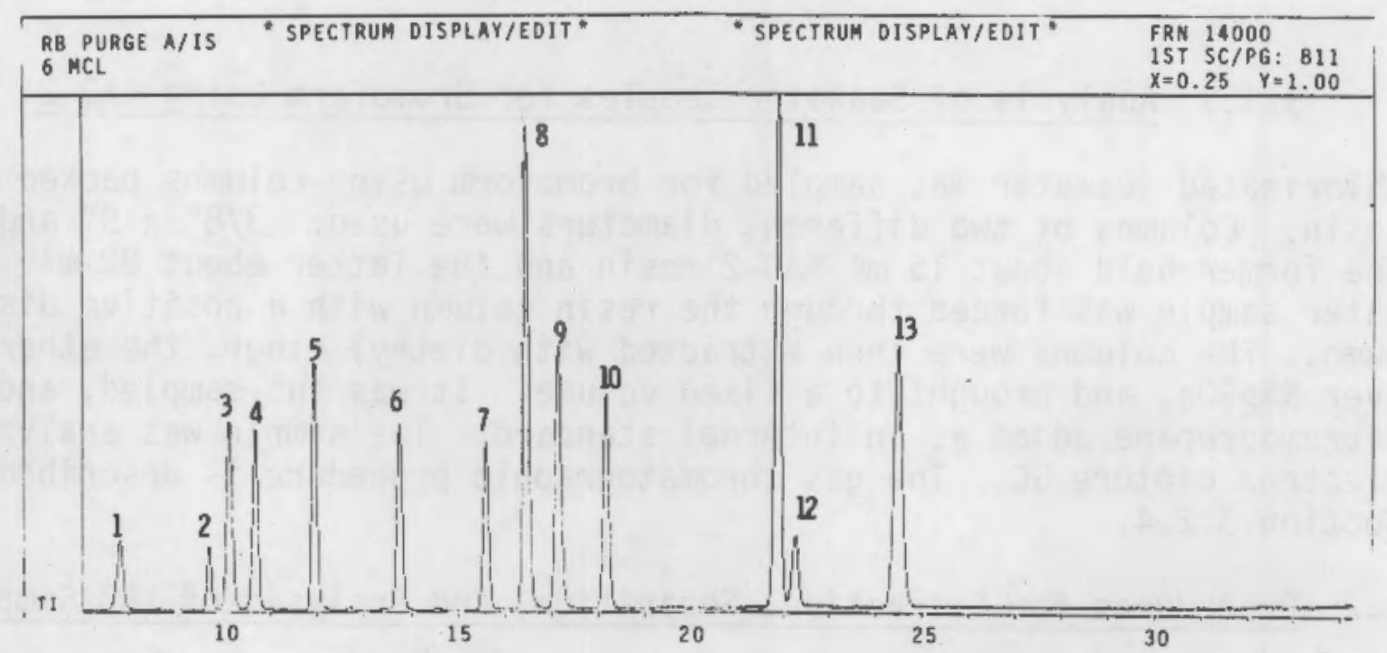
1. $\mathrm{CH}_{2} \mathrm{Cl}_{2}$
2. 1, 1-DICHLOROETHYLENE
8. TRICHLOROETHYLENE
3. INT. STD $\#$
9. $\mathrm{CHBrxCl}$
4. 1, I-DICHLOROETHANE
10. INT. STD 12
5. $\mathrm{CHCl}_{3}$
11. TETRACHLOROETHYLENE
6. $\mathrm{CCl}_{4}$
12. INT. STD $\$ 3$
7. 1,2-DICHLOROPROPANE
13. CHLOROBENZENE

FIGURE 4. Total Ionization Chromatogram of Purge-and-Trap Standards Mixture "A". Component concentrations are about $34 \mu \mathrm{g} / l$ in water.

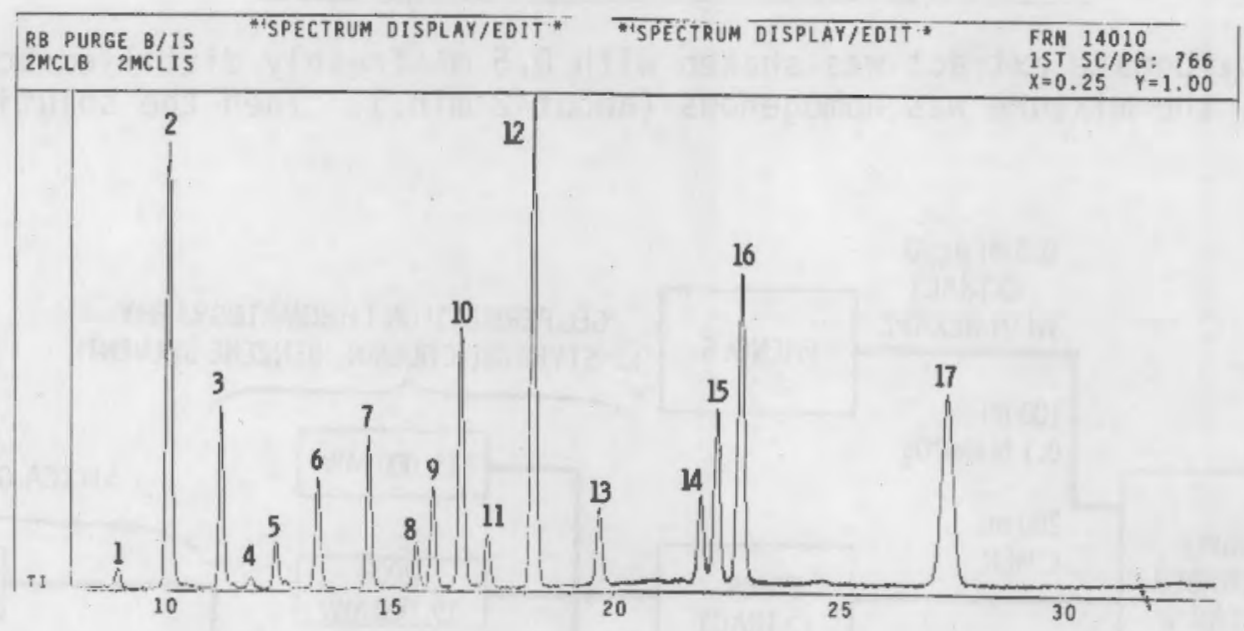

1. $\mathrm{CFCl}_{3}$

2. INT. STO \#1

3. 1,2-DICHLOROETHYLENE

4. $\mathrm{CHCl}_{3}$ (IMPURITY)

5. 1,2-DICHLOROETHANE

6. 1, 1, 1-TRICHLOROETHANE

7. $\mathrm{CHBrCl}_{2}$

8. 1,2-DICHLOROPROPANE

9. TRANS-1,3-DICHLOROPROPENE
10. BENZENE

11. CIS-1,3-DICHLOROPROPENE

12. INT. STD \#2

13. $\mathrm{CHBr}_{3}$

14. 1, 1,2,2-TETRACHLOROETHANE

15. INT. STD \#3

16. TOLUENE

17. ETHYLBENZENE

FIGURE 5. Total Ionization Chromatogram of Purge-and-Trap Standards Mixture "B". Component Concentrations are about $11 \mu \mathrm{g} / \ell$ in water. 


\subsubsection{Analysis of Seawater Samples for Bromoform Using XAD-2}

Chlorinated seawater was sampled for bromoform using columns packed with XAD-2 resin. Columns of two different diameters were used: $3 / 8^{\prime \prime} \times 9^{\prime \prime}$ and $7^{\prime \prime} \times 9^{\prime \prime}$. The former held about $15 \mathrm{ml}$ XAD-2 resin and the latter about $82 \mathrm{ml}$. The seawater sample was forced through the resin column with a positive displacement pump. The columns were then extracted with diethyl ether, the ether dried over $\mathrm{Na}_{2} \mathrm{SO}_{4}$, and brought to a fixed volume. It was sub-sampled, and then 1,3dibromopropane added as an internal standard. The sample was analyzed by electron capture GC. The gas chromatographic procedure is described in Section 3.2.4.

\subsection{Procedures for Extraction, Separation, and Analysis of XAD Samples}

The XAD-2 columns used for the high-volume sampling of chlorinated water and controls were first extracted with $100 \mathrm{me} 0.1 \mathrm{~N} \mathrm{Na} 2 \mathrm{CO}_{3}$ solution to remove phenols. Then the columns were extracted with $200 \mathrm{ml}$ ethyl ether, and finally, $100 \mathrm{ml} \mathrm{MeOH}$. The treatment of each of these fractions is described below. The overall separation scheme is presented in Figure 6 . For the procedures described below, all solvents used were Burdick and Jackson "Distilled in Glass?" with the exception of ether (Mallinckrodt absolute ether) and water which was $18 \mathrm{M}$ (Millipore--R080 purification system). All solvents were routinely checked for haloforms by GC and chlorine by microcoulometry prior to use.

\subsubsection{Derivatization and Separation of Phenols}

The carbonate extract was shaken with $0.5 \mathrm{ml}$ freshly distilled acetic anhydride until the mixture was homogenous (about $2 \mathrm{~min}$.). Then the solution was extracted

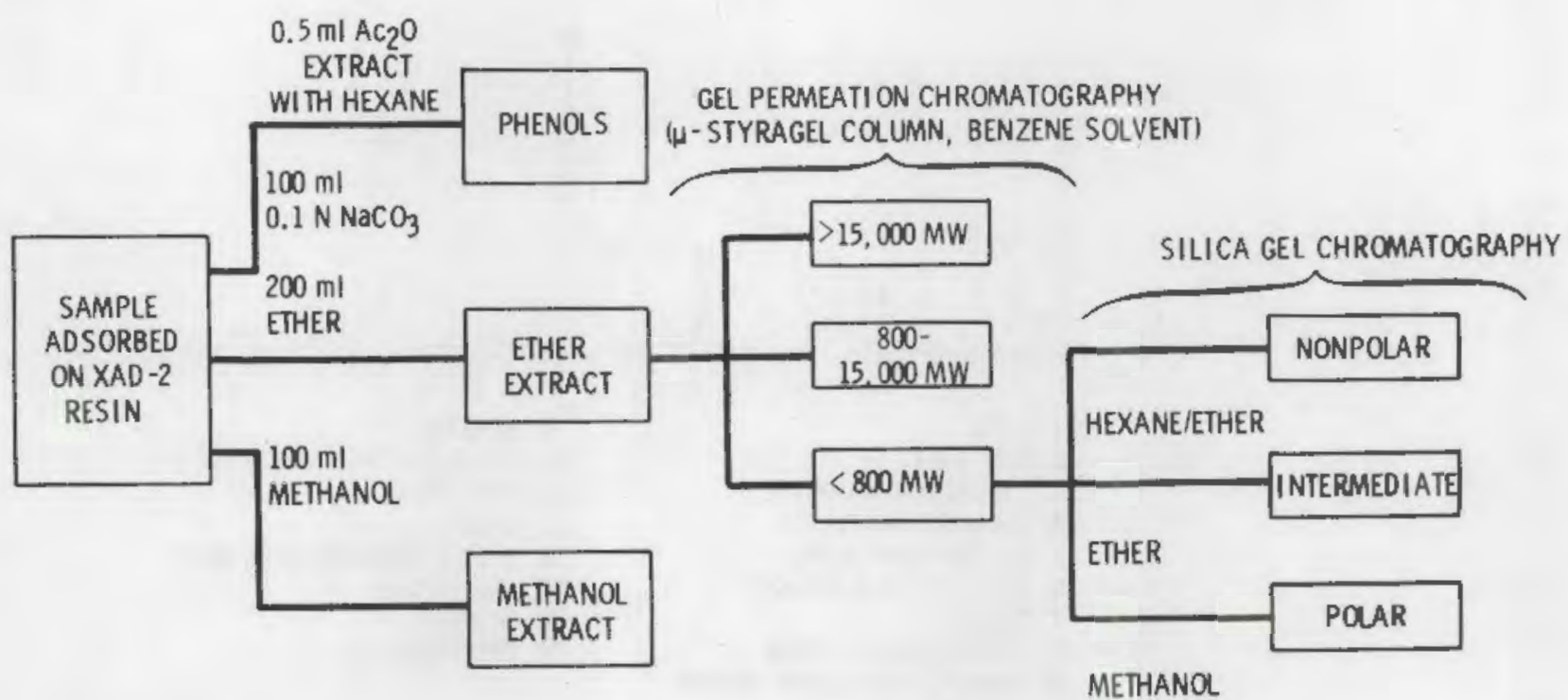

FIGURE 6. Separation Scheme for Chlorinated Water Sampled by XAD-2 Adsorption Technique 
into $10 \mathrm{me}$ Hexane. The presence of emulsions in some of the samples necessitated centrifuging at $3500 \mathrm{rpm}$. One me $n$-heptane was added, and the sample evaporated to $1 \mathrm{me}$ prior to analysis by $\mathrm{GC} / \mathrm{MS}$.

\subsubsection{Separation of Components in Ether Extracts According to Molecular Weight}

The dried ether extract was subsampled for analys is of haloform constituents, and was then evaporated by using Snyder columns to a few milliliters. The solvent was then exchanged into $1 \mathrm{me}$ benzene and injected into a Waters model $6000 \mathrm{~A}$ liquid chromatograph containing three series coupled $100 \AA$ microstyragel columns. Separation of components in the extract into molecular weight fractions of $>15,000,800-15,000$, and $<800$ was accomplished at a benzene flow rate of one ml/min by collecting fractions at 7-10 ml, 10-13 $\mathrm{ml}$, and 13-30 me, respectively. Fraction collection volumes were determined by using polystyrene and polyethylene glycol calibration standards provided by the instrument manufacturer.

\subsubsection{Separation of Components in $<800$ Molecular Weight Fraction According to Polarity.}

The $<800 \mathrm{MW}$ fraction from the microstyragel separation was evaporated and the solvent exchanged to $1 \mathrm{me} n$-heptane. The sample was placed on 7.0 grams of silica gel deactivated with $10 \%(\mathrm{~W} / \mathrm{W})$ deionized water and slurry-packed into a $9 \times 250$ man Chromaflex column using $n$-hexane. The column was successively eluted with $20 \mathrm{me} 80 \%$ hexane/20\% diethyl ether, $20 \mathrm{ml} 100 \%$ diethyl ether, and 20 me methanol. Fractions were removed after each of the eluants had percolated and the column and were designated "Non-Polar," "Intermediate," and "Polar" silica gel fractions.

\subsubsection{Analysis of Ether Extracts for Haloforms}

Analysis of the XAD-2 column extracts for haloforms was performed by adding $5 \mu \ell$ of a solution of $100 \mu \mathrm{l} 1,3$-dibromopropane in $100 \mathrm{ml}$ methanol as an internal standard to exactly $1 \mathrm{me}$ of the ether extract in a teflon-lined septum-capped 2 me vial, mixing thoroughly, and injecting one microliter onto a glass, $2 \mathrm{~mm} x$ 6 -foot Chromosorb 100 gas chromatographic column held at $190^{\circ} \mathrm{C}$ in a HewlettPackard 5840 chromatograph equipped with an electron capture detector. A typical chromatogram is given in Figure 7. The concentrations of individual haloforms were determined from calibration curves prepared using analytical standards. The total quantity in the sample was then determined by multiplying the determined concentration in $\mu \mathrm{g} / \ell$ by the volume of the original ether extract.

\subsubsection{Total Organic Ha logen Measurements--Microcoulometry}

A Dohrman/Envirotech Microcoulometric Titration System was used for determination of chlorine in the original ether extracts and separated fractions. The detection system is based upon changes in half-cell potential of a $\mathrm{Ag}^{+} / \mathrm{Ag}^{\circ}$ couple brought about by reaction of silver ion with $\mathrm{Cl}^{-}$or $\mathrm{OCL}^{-}$formed from the combustion of the sample. The current required to restore electrical balance in the cell is a measure of the halogen in the sample. The instrument provides 


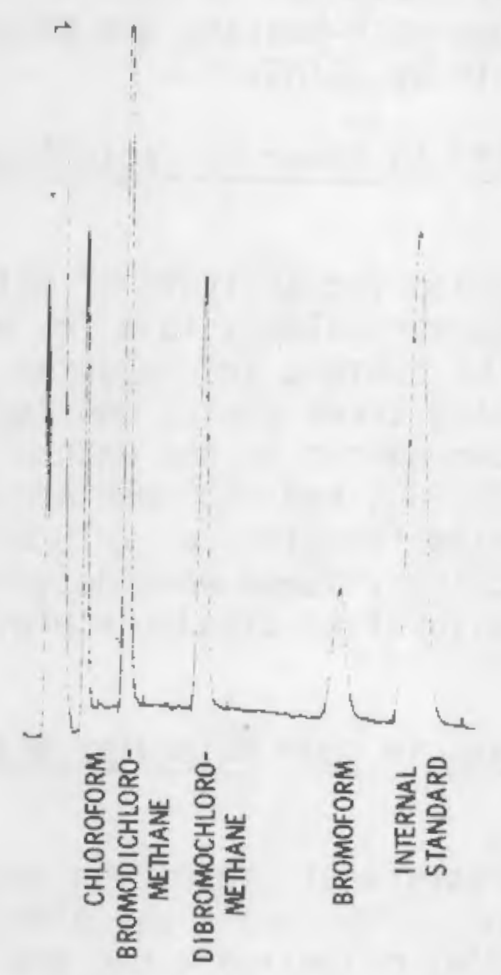

FIGURE 7. Gas Chromatogram of Ether Extract

a direct readout in $\mu \mathrm{g}$ chlorine per me sample. Known concentrations of halogenated organics must be analyzed to determine the combustion/titration efficiency, which for most chlorine-containing compounds is about $85 \%$. For bromine containing compounds, the recovery is about $50 \%$ since $\mathrm{AgOBr}$ does not precipitate. This leads to indeterminate errors in those samples in which there are substantial quantities of both bromine- and chlorine-containing components. In seawater systems, the majority of the organohalogen formed from chlorination is organobromine; hence brominated standards are used for calibration. In some of the freshwater samples, there was sufficient bromide in the water to cause errors in the analysis. The organohalogen in these samples may be underestimated by as much as $15 \%$.

\subsection{GC/MS Analyses of Separated Fractions}

Gas chromatography/mass spectrometry was conducted using a Hewlett-Packard Model 5985 GC/MS system employing a 5840 gas chromatograph and capillary injection system. Chromatographic separation was accomplished using $0.25 \mathrm{~mm} \times$ $30 \mathrm{~m}$ glass capillary columns from Supelco coated with SP2250 liquid phase. Samples were placed on the column in the splitless mode using n-heptane as a soivent. Mass spectrometric conditions varied widely depending upon the nature of the sample and condition of the source. However, conditions were optimized for maximum sensitivity. Gas chromatographic conditions were a 4-min hold at $70^{\circ} \mathrm{C}$ followed by a temperature program at $4^{\circ} \mathrm{C} / \mathrm{min}$ and a hold at $250^{\circ} \mathrm{C}$. Samples 
were analyzed using methane chemical ionization mode in order to obtain the reouired sensitivity to halogenated components. In addition, for the XAD-2 ether extract samples, the column effluent was split to direct part of the effluent through an electron capture detector in order to assist in the location of those chromatographic peaks containing halogen.

\subsection{Analysis of River and Sea Waters for $\mathrm{Br}$ and $\mathrm{Cl}$ by Ion Chromatography}

Bromide and chloride analyses were performed via a Dionex Model 10 ion chromatograph. Briefly, ion chromatography (IC) is ion exchange separation followed by eluent suppression and conductimetric detection. A low capacity anion exchange resin separates the anions in the element stream. This stream passes through the suppressor column, a high capacity cation resin, where eluent and sample ions are converted to their acidic forms. Eluents are chosen which result in low-conducting species at this point. The eluent stream proceeds to the conductivity cell, where ions of interest are detected as peaks against the eluent's low-conductance background. For those anions displaying the normal (gaussian) shape, peak height is proportional to concentration over a wide range of concentrations.

System specifications employed for the analysis of $\mathrm{Br}^{-}$and $\mathrm{Cl}^{-}$are as follows:

\section{Sample Size Options:}

Eluent: $\quad 3 \mathrm{mM} \mathrm{NaHCO} 3+2.4 \mathrm{mM} \mathrm{Na} 2 \mathrm{CO}_{3}$

$$
\begin{aligned}
& \text { Size Options: } \text { (1) } 100 \lambda \text { loop } \\
& \text { (2) } 50 \mathrm{~mm} \text { concentrator column } \\
& \text { Column System: } 150 \mathrm{~mm} \text { anion precolumn } \\
& \\
& \text { Flow Rate: } 152 \mathrm{~mm} \text { anion separator column } \\
& \text { Flon }
\end{aligned}
$$

Under these conditions, $\mathrm{Cl}^{-}$eluted at 3.9 min while $\mathrm{Br}^{-}$eluted at 9.5 min. Other anions and their retention times, which were determined simultaneously are $\mathrm{F}(2.4 \mathrm{~min})$; $\mathrm{PO}_{4}{ }^{3-}(7.2 \mathrm{~min}), \mathrm{NO}_{3}^{-}(10.8 \mathrm{~min})$ and $\mathrm{SO}_{4}(16.2 \mathrm{~min})$. River water samples were initially_run using the $100 \lambda$ sample $100 p$, to determine $\mathrm{Cl}^{-}$ and get an upper limit on $\mathrm{Br}^{-}$concentration. Sea water samples required 100fold dilution prior to analysis. 



\section{EVALUATION/VALIDATION OF QUANTITATIVE METHODS}

During the course of these investigations, considerable effort was spent in characterizing and validating the analytical methods used. Validation of methods was undertaken for several reasons. Some of the methods were developed specifically for this program. In particular, the XAD-2 extraction and separation scheme for the less volatile chloroorganic compounds was developed to meet the objectives of the program, and hence considerable recovery data was generated in the process. Other techniques, such as the headspace (Bush, et a1., 1977), purge-and-trap (Bellar and Lichtenberg, 1974), and microcoulometric analysis (Glaze, 1977; Wegman and Greve, 1977), have been reported in the 1iterature, but were modified sufficiently in our hands so as to require additional investigation. Certain procedures such as the XAD-2 adsorption technique (Glaze, et a1., 1977; Junk, et al, 1974) were not evaluated because of the large data base already in existence. Validation studies were not conducted with the phenol fractions because the derivatization/gas chromatographic procedure has been documented by Krijgsman and Van de Camp (1977), and because the data generated from our studies was largely qualitative.

\subsection{Volatiles Analyses}

Total ionization chromatograms from the Purge-and-Trap analysis of two sets of analytical standards containing 23 of the components designated as EPA priority pollutants (a) (Environmental Protection Agency, 1977) are presented in Figures 4 and 5. A11 environmental samples analyzed by the "Purge and Trap" technique were examined for spectra indicative of these components. Levels at which components could be quantitated are estimated to be $0.5 \mathrm{mg} / 1$. Detection levels are lower than this $(20.1 \mathrm{mg} / 1)$ when reconstructed single ion chromatograms were examined. Mixtures of the four haloforms and $\mathrm{CS}_{2}$ and $\mathrm{CH}_{2} \mathrm{Cl}_{2}$ were prepared at three concentration levels and analyzed in order to prepare quantiative calibration curves. These are shown in Figure 8 , where the peak area divided by the internal standard area is plotted against component concentration. Under the experimental conditions used, plots of three of the four haloforms were linear over the range of concentrations examined. Bromoform was not linear with concentration. This is presumably because bromoform's low vapor pressure $\left(b p=149^{\circ} \mathrm{C}\right)$ did not permit quantitative removal from the water. On the other hand the very volatile components $\left(\mathrm{CS}_{2}\right.$ and $\left.\mathrm{CH}_{2} \mathrm{Cl}_{2}\right)$ also did not fit a straight line, but the curvature is opposite to that of bromoform. This suggests that at low concentrations, these highly volatile components are rapidiy removed from the water, and as purging continues, are also volatilized from the trap. Hence, levels of detection are relatively high for these two components compared to the others. In all cases, accuracy suffers as concentration is increased. This was true regardless of the internal standard used for quantitation. Internal Standard \#2 gave the most consistent results. Data for the highest concentrations are based on four replicate analyses, while for the two lower concentrations, data are based on three replicate analyses.

(a) Supplied by Supe1co, Inc. as "Purgable A", and "Purgable B"; each component $0.2 \mathrm{mg} / \mathrm{me}$ in methanol. 


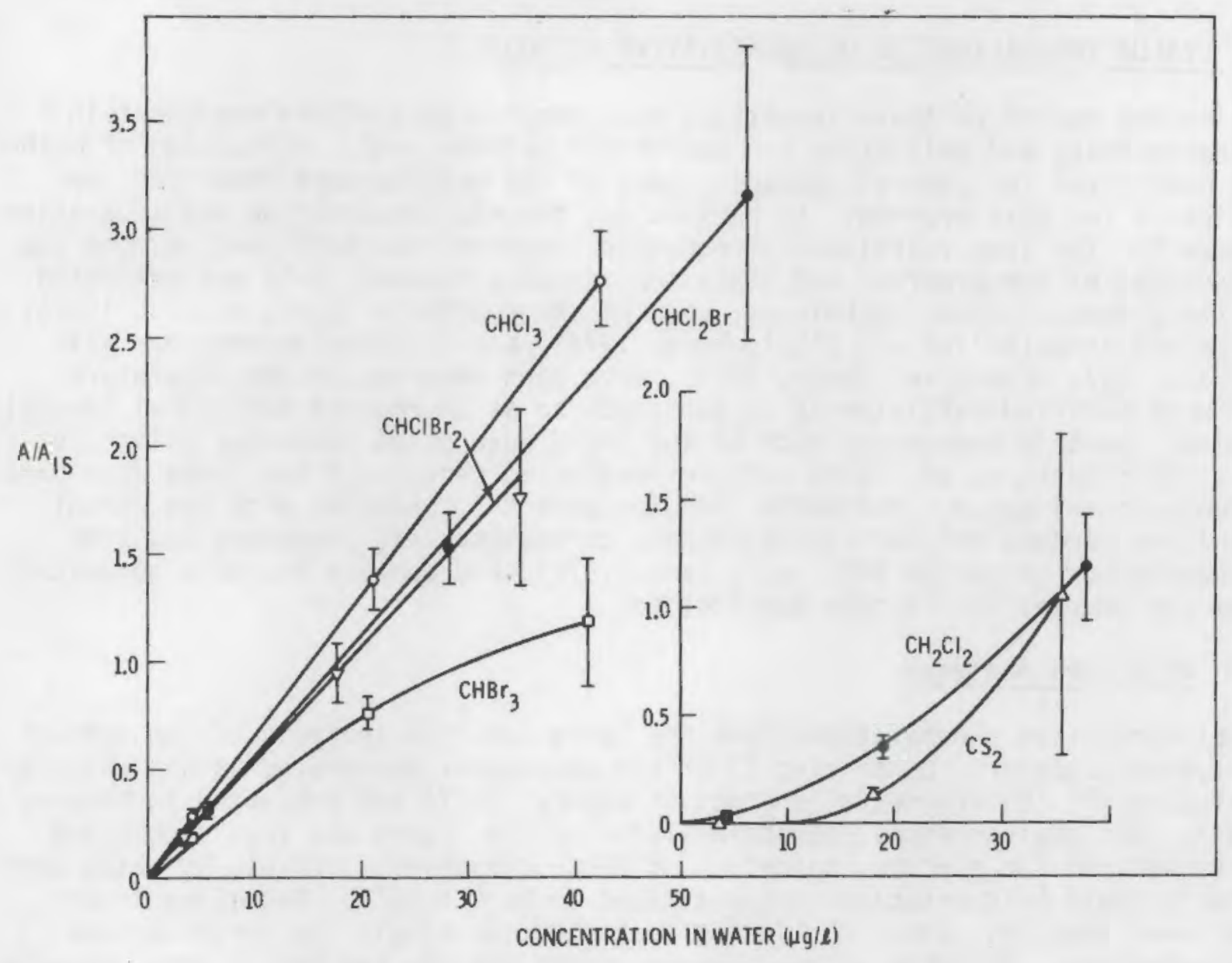

FIGURE 8. Calibration Curve for Purge and Trap Technique

The calibration curve constructed from chloroform standards using the headspace method (Fig. 9) shows that within the range studied, there was some deviation from 1 inear response. Error bars on the calibration curve represent triplicate analyses. Because the absolute response of the electron capture detector is variable from day to day, it was impractical to construct a new calibration curve each day. Quantitation was accomplished by comparison of the sample peak areas to those of standards having concentrations close to the sample concentrations.

Standard samples and duplicate samples gave reproducible results even after weeks of storage at $4^{\circ} \mathrm{C}$. However, results were low if the samples were not heated for at least one hour prior to headspace sampling. The prolonged heating requirement is apparently required to release the haloform from the absorbed state in the septum. The Hycar ${ }^{\circledR}$ septa were found to have a high affinity for chloroorganics in the vapor phase. It is for this reason that the headspace method was not used for the analysis of higher molecular weight haloforms. Although reasonably linear calibration curves could be prepared using bromoform, the apparent concentrations in the samples would drop in a period of 24 hours. 


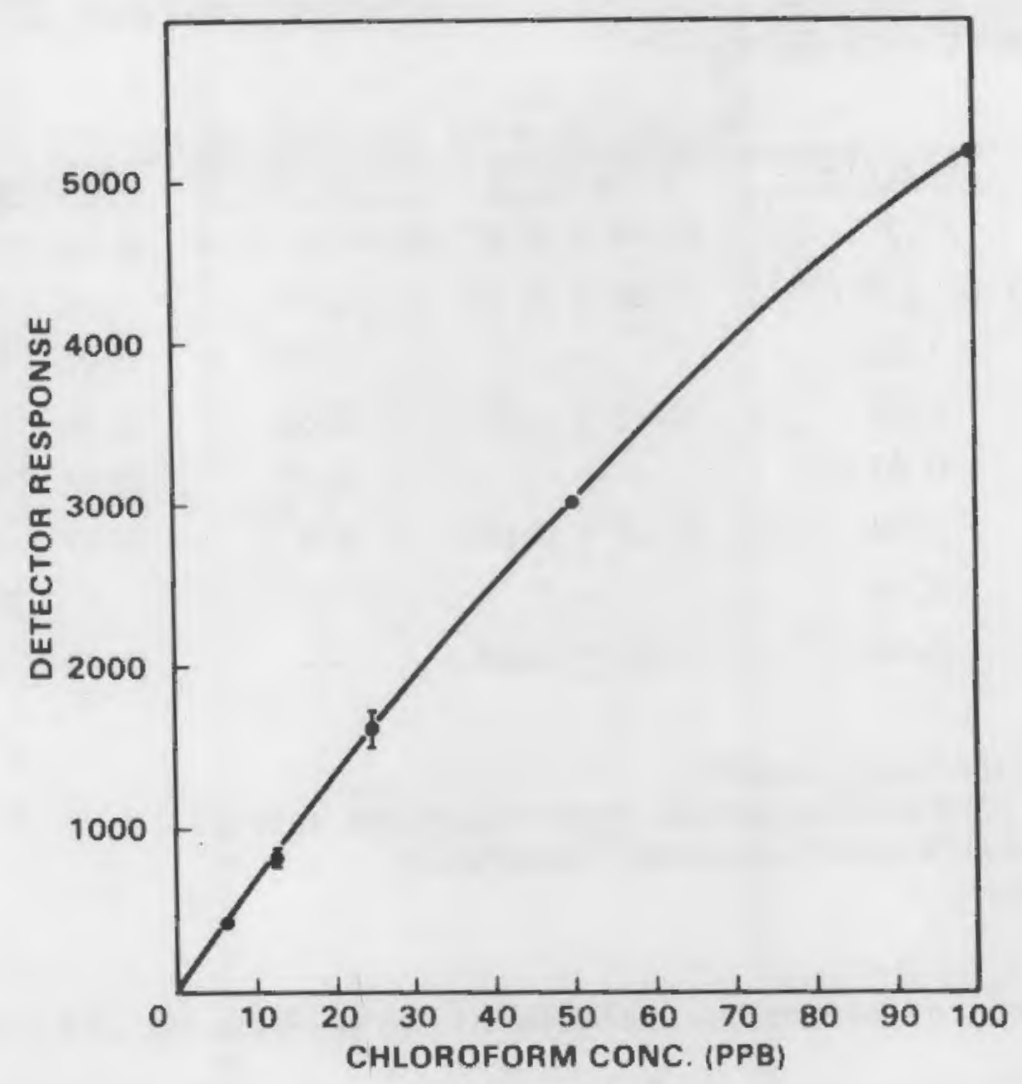

FIGURE 9. Calibration Curve for $\mathrm{CHCl}_{3}$ Using the Headspace Method

The headspace method was initially applied to a low level biological exposure experiment in order to evaluate the method as a potential field technique. Chloroform analyses obtained from this experiment are given in Table 1. The sample indicated "concentrate" is river water to which has been added about $2 \mathrm{mg} / \ell$ chlorine as $\mathrm{NaOCl}$. The "100 \%" sample is the highest level to which organisms are exposed. This level is actually a 16-fold dilution of the concentrate. Differences in chloroform concentration between the concentrate and dilutions are actually greater than would be calculated from the dilution factor because of volatility losses during mixing. On $5 / 22$ and $6 / 16$, sampling was limited to one sample per exposure concentration. On 5/26, however, 5 concentrations were sampled in triplicate to determine the method reproducibility. The reproducibility of the method appeared satisfactory for the intended use.

In some instances, analyses of bromoform in chlorinated sea water or chlorinated estuarine water were performed by adsorption from water onto XAD-2 res in columns and subsequent gas chromatography of the column ether extract. This methodology has been described by Glaze et a7. (1977). We investigated the efficiency of recovery of both bromoform and chioroform on XAD-2 resins. During bromoform sampling, two columns were placed in series and the quantity of bromoform on each column determined. The results of the analyses for the three salt water locations investigated in this work appear on Table 2. The $3 / 8^{\prime \prime} \times 9 "$ columns contain about $15 \mathrm{me}$ XAD-2 resin and were used to adsorb the bromoform from 
TABLE 1. Chloroform Headspace Analysis: Freshwater Low-Level Chlorination Experiment with Salmonids

\begin{tabular}{|c|c|c|c|c|}
\hline & \multicolumn{4}{|c|}{ (Values reported are $\mu \mathrm{g} / \mathrm{l} \quad \mathrm{CHCl} 3$ ) } \\
\hline & $5 / 22 / 78$ & $5 / 26 / 78(b)$ & $6 / 16 / 78$ & Average \\
\hline Concentrate & 31.3 & $40.16 \pm 1.39$ & $39.09 \pm 1.15$ & $36.85 \pm 4.83$ \\
\hline "100\%" & $1.05 \pm 0.21^{(\mathrm{a})}$ & $1.03 \pm 0.11$ & 0.93 & $1.00 \pm 0.06$ \\
\hline "75\%" & 1.00 & -- & 0.83 & $0.92 \pm 0.12$ \\
\hline "50\%" & 0.54 & $0.70 \pm 0.00$ & 0.69 & $0.64 \pm 0.08$ \\
\hline "25\%" & 0.41 & -- & 0.62 & $0.52 \pm 0.15$ \\
\hline$" 12.5 \% "$ & 0.49 & $0.47 \pm 0.05$ & $0.6^{\text {(c }}$ & $0.52+0.07$ \\
\hline "O\%" & 0.46 & -- & $n d^{(d)}$ & 0.23 \\
\hline er Water & 0.46 & $0.39 \pm 0.04$ & -- & $0.43 \pm 0.05$ \\
\hline
\end{tabular}
(a) Average of duplicate samples
(b) Analyses on $5 / 26$ were obtained from triplicate samples
(c) Estimate, interference with peak integration
(d) Not detected

TABLE 2. Comparison of Bromoform Analyses at Three Seawater Stations ( $\mu \mathrm{g} / 1 \mathrm{iter}$ )

\begin{tabular}{|c|c|c|}
\hline Sample & $\begin{array}{c}3 / 8 \text { in. } \times 9 \text { in. } \\
\text { Column } \\
\end{array}$ & $\begin{array}{c}1 \text { in. } \times 9 \text { in } \\
\text { Column } \\
\end{array}$ \\
\hline $\begin{array}{l}\text { Sequim Bay } \\
\text { Top Column } \\
\text { Bottom Column }\end{array}$ & $\begin{array}{c}20.8 \\
--\end{array}$ & $\begin{array}{r}11.1 \\
4.2\end{array}$ \\
\hline Total & 20.8 & 15.3 \\
\hline $\begin{array}{l}\text { Cape Fear } \\
\text { Top Column } \\
\text { Botton Column }\end{array}$ & & $\begin{array}{l}36.3 \\
18.2\end{array}$ \\
\hline Total & & 54.5 \\
\hline $\begin{array}{l}\text { San Onofre } \\
\text { Top Column A } \\
\text { Bottom Column A }\end{array}$ & $\begin{array}{r}11.1 \\
3.3\end{array}$ & $\begin{array}{r}15.3 \\
6.2\end{array}$ \\
\hline Total & 14.4 & 21.5 \\
\hline $\begin{array}{l}\text { Top Column B } \\
\text { Bottom Column B }\end{array}$ & $\begin{array}{r}13.9 \\
5.6\end{array}$ & \\
\hline Total & 19.5 & \\
\hline
\end{tabular}


5 liters of water. The $1^{\prime \prime} \times 9^{\prime \prime}$ columns contain about $82 \mathrm{me}$ and were used to adsorb the bromoform from about 200 liters of water. Regardless of column size or amount of water sampled, between $72 \%$ and $78 \%$ of the bromoform was found on the top column; with the exception of Cape Fear where $67 \%$ of the bromoform was adsorbed on the top column. We believe that the large differences between top and bottom columns is an indication of satisfactory adsorption efficiency of bromoform. Additional1y, an independent analys is for bromoform was obtained from the San Onofre location using the purge-and-trap technique. The results (13 and $17 \mu \mathrm{g} / \ell--$ see Table 8 ) are consistent with those obtained from the adsorption analyses $(19.5,14.4,21.5 \mu \mathrm{g} / \mathrm{l})$.

On the other hand, the data presented in Table 3 shows that XAD- 2 resin columns do not efficiently adsorb chloroform from water. In this case, only $10 \%$ of the available chloroform (as analyzed by the headspace method) was trapped on the XAD-2 column under the same conditions which trapped almost all the bromoform (Table 2, sea water system). The data in Table 3 was also generated in order to estimate the losses in volatiles occurring because of the transfer of the chlorinated water from the contact chamber to the sampling chamber when the continuous sampling apparatus was used (see Figure 1). In the case of both fresh and salt water, volatilization losses of the major haloform constituents appear to be about $10 \%$. We would therefore expect that the chloroform results obtained by headspace analysis would be generally higher than those obtained by purge-and-trap, since the former were sampled from the chlorination chamber and the latter from the sampling chamber.

\subsection{XAD-2 Samples: Procedural Recoveries from Separation Scheme}

For these studies a set of standards supplied by Supelco, Inc. designated "BaseNeutral \#1" were used. The compounds in this mixture are on EPA's priority pollutant list (USEPA, 1977). Approximately $10 \mu \mathrm{g}$ of each component listed in Tables 4-7, were used for the recoveries. All the recovery data were acquired

TABLE 3. Comparison of Methods of Haloform Analyses of Chlorinated Waters

Freshwater Systems $\left(\mathrm{CHCl}_{3}\right)$

\begin{tabular}{c} 
Headspace Directly \\
from Contact \\
Chamber $(\mu \mathrm{g} / \mathrm{\ell})$ \\
\hline
\end{tabular}

$38.3,39.9 ; \bar{x}=39.1$

5 \& over XAD-2

Directly from Contact Chamber $(\mu \mathrm{g} / \mathrm{l})$

$16.8,17.2 ; \bar{x}=17.0$
Headspace from

Sampling Chamber $(\mu \mathrm{g} / \mathrm{l})$

$35.1,35.3 ; \bar{x}=35.2$

Seawater System $\left(\mathrm{CHBr}_{3}\right)$

5 \& over XAD-2

from Sampling

Chamber $(\mu \mathrm{g} / \ell)$

15.4
XAD-2 column

(388 liters over

$82 \mathrm{m \ell} \operatorname{Resin})(\mu \mathrm{g} / \mathrm{l})$

3.2

XAD-2 Column (335 liters over $82 \mathrm{ml}$ Resin) $(\mu \mathrm{g} / \mathrm{l})$

15.0 
TABLE 4. Procedural Recoveries---Ether Evaporation

\begin{tabular}{|c|c|c|c|c|c|c|}
\hline Compound (a) & A & B & $c$ & Average & $\begin{array}{l}\text { Standard } \\
\text { Deviation }\end{array}$ & $\begin{array}{c}\text { Coefficient } \\
\text { of } \\
\text { Variation } \\
\end{array}$ \\
\hline $\begin{array}{l}\text { 1, } 4 \text { Dichlorobenzene }(\mathrm{b}) \\
\text { Bis (2-Chloroethyl) ether }\end{array}$ & 89.0 & 90.8 & 90.8 & 90.2 & 1.0 & $1.2 \%$ \\
\hline Bis (2-Chloroisopropyl) ether & 85.7 & 85.0 & 87.6 & 86.1 & 1.3 & $1.5 \%$ \\
\hline Nitrobenzene & 89.6 & 90.8 & 93.2 & 91.2 & 1.8 & $2.0 \%$ \\
\hline Acenaphthylene & 81.8 & 81.6 & 82.5 & 82.0 & 0.5 & $0.6 \%$ \\
\hline Dimethylphthalate & 92.4 & 93.5 & 92.6 & 92.8 & 0.6 & $0.6 \%$ \\
\hline 2,6-Dinitrotoluene & 89.5 & 90.6 & 90.3 & 90.1 & 0.6 & $0.6 \%$ \\
\hline 4-Bromopheny 1 -pheny 1 -ether & 93.4 & 95.6 & 96.4 & 95.1 & 1.6 & $1.6 \%$ \\
\hline Dibutylphthalate & 90.5 & 89.6 & 90.9 & 90.3 & 0.7 & $0.7 \%$ \\
\hline Bis-(2-Ethylhexyl)phthalate & 105.5 & 112.5 & 115.1 & 111.0 & 5.0 & $4.5 \%$ \\
\hline
\end{tabular}

(a) 3,3'-Dichiorobenzidene and Benzo(B)Fluoranthene were not recovered

(b) These two compounds co-elute

TABLE 5. Procedural Recoveries--Gel Permeation Chromatography

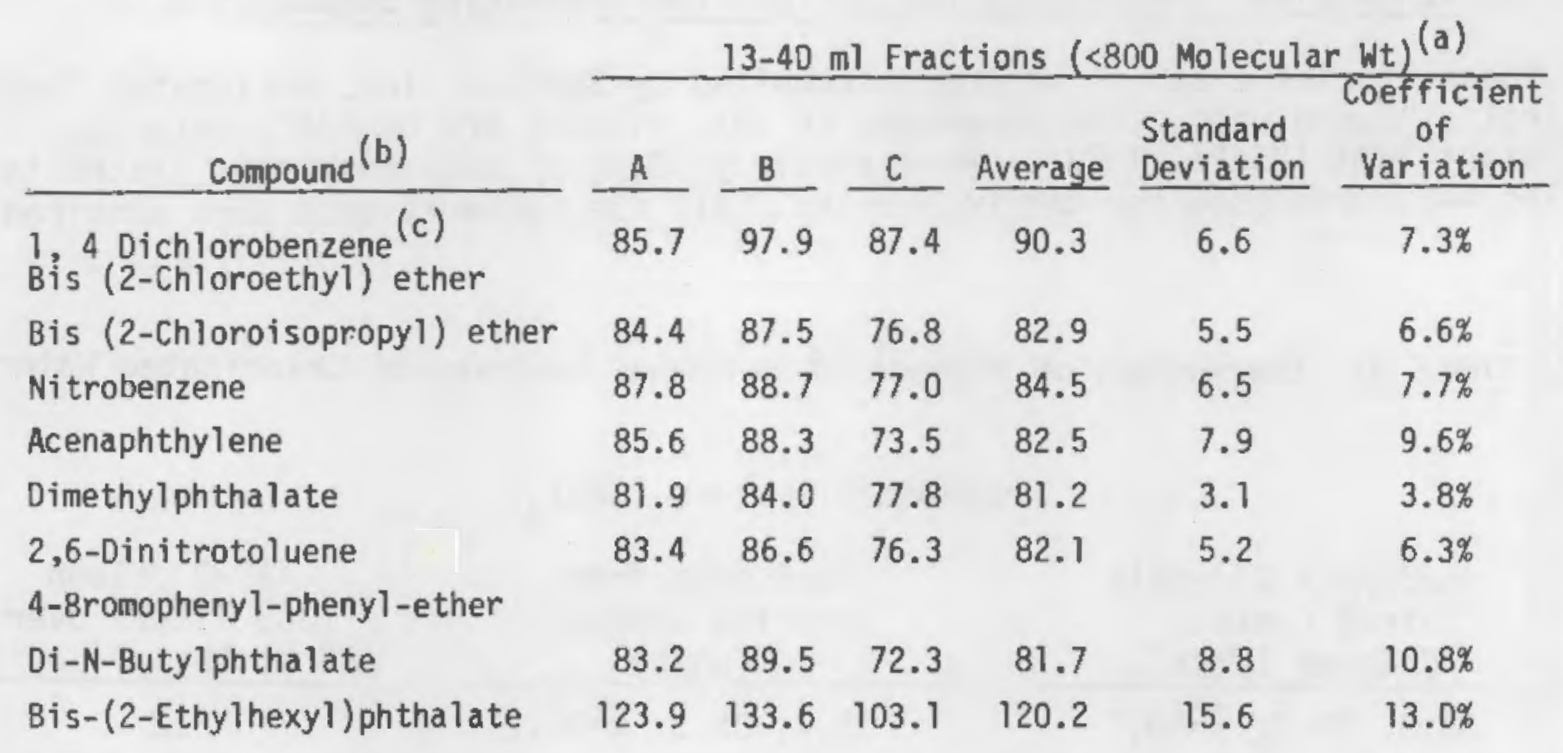

(a) No traces of any component were found in the 7-10 $\mathrm{ml}$ ( $<15,000$ molecular wt) or 10-13 m1 (15,000-800 molecular wt) fractions.

(b) 3,3'-Dichlorobenzidene and 8enzo(b)fluoranthene were not recovered.

(c) These two compounds co-elute. 


\section{TABLE 6. Procedural Recoveries--Silica Gel Chromatography}

\begin{tabular}{|c|c|c|c|c|c|c|c|c|c|}
\hline \multirow[b]{2}{*}{ Compound } & \multicolumn{3}{|c|}{$\begin{array}{c}\text { First Fraction } \\
80 / 20 \\
\text { Hexane/Ether (a) }\end{array}$} & \multicolumn{3}{|c|}{$\begin{array}{l}\text { Second Fractipn } \\
100 \% \text { Ether }(a)\end{array}$} & \multirow[b]{2}{*}{ Average } & \multirow{2}{*}{$\begin{array}{l}\text { Standard } \\
\text { Deviation }\end{array}$} & \multirow{2}{*}{$\begin{array}{c}\text { Coefficient } \\
\text { of } \\
\text { Variation } \\
\end{array}$} \\
\hline & $A$ & $B$ & $C$ & A & $\bar{B}$ & $C$ & & & \\
\hline $\begin{array}{l}\text { 1, } 4 \text { Dichlorobenzene }{ }^{(b)} \\
\text { Bis }(2-C h l \text { oroethyl) ether }\end{array}$ & 67.8 & 69.0 & 75.2 & & & & 70.7 & 4.0 & $5.6 \%$ \\
\hline Bis (2-Chloroisopropyl) ether & 66.9 & 74.7 & 86.2 & & & & 75.9 & 9.7 & $12.8 \%$ \\
\hline Nitrobenzene & 61.9 & 69.8 & 73.1 & & & & 68.3 & 5.8 & $8.5 \%$ \\
\hline Acenaphthalene & 69.1 & 76.1 & 81.4 & & & & 75.5 & 6.2 & $8.2 \%$ \\
\hline Dimethylphthalate & $\operatorname{tr}$ & $\operatorname{tr}$ & $\operatorname{tr}$ & 85.0 & 78.0 & 79.6 & 80.9 & 3.7 & $4.6 \%$ \\
\hline 2,6-Dinitrotoluene & 69.7 & 72.8 & 77.6 & & & & 73.4 & 4.0 & $5.5 \%$ \\
\hline 4-Bromophenyl-phenyl-ether ${ }^{(c)}$ & & & & & & & & & \\
\hline Di-N-Butyl phathalate & 76.3 & 78.8 & Bo.9 & & & & 78.7 & 2.3 & $2.9 \%$ \\
\hline Bis(2-Ethylhexyl)phthalate & 97.9 & 79.1 & 94.4 & & & & 90.5 & 10.0 & $11.0 \%$ \\
\hline
\end{tabular}

(a) Ether used was $25 \% \mathrm{H}_{2} \mathrm{O}$ saturated.

(b) These two compounds co-elute.

(c) 3,3'-Dichlorobenzidene and Benzo(b)fluoranthene were not recovered.

The third fraction $(100 \% \mathrm{MeOH})$ was not examined due to solvent incompatibility with the gas chromatography column.

\section{TABLE 7. Overall Procedural Recoveries}

\begin{tabular}{|c|c|c|c|c|c|c|c|c|}
\hline Standard Compound & \multicolumn{3}{|c|}{$\begin{array}{r}\text { Silica Gel-1st Cut } \\
(80 / 20 \text { Hexane/Ether })\end{array}$} & \multicolumn{3}{|c|}{$\begin{array}{l}\text { Silica Gel-2nd Cut } \\
\text { (100\% Ether) }\end{array}$} & Mean \pm s.d. & $\begin{array}{l}\text { Coefficient } \\
\text { of Variation }\end{array}$ \\
\hline 1,4-Dichlorobenzene ${ }^{(a)}$ & 49.5 & 44.9 & 58.2 & & & & $50.9 \pm 6.78$ & 13.2 \\
\hline Bis (2-Chloroethyl) ether & & & & & & & & \\
\hline Bis (2-Chloroisopropyl) ether & 52.1 & 44.5 & 60.5 & & & & $52.4 \pm 8.0$ & 15.3 \\
\hline Nitrobenzene & 53.5 & 47.5 & 65.2 & & & & $55.4 \pm 9.0$ & 16.2 \\
\hline Acenaphthylene & 65.6 & 56.4 & 87.7 & & & & $69.9 \pm 16.1$ & 23.0 \\
\hline Dimethylphthalate & $\operatorname{tr}$ & $\operatorname{tr}$ & $\operatorname{tr}$ & 57.6 & 60.6 & 70.1 & $62.8 \pm 6.5$ & 10.4 \\
\hline 2,6-Dinitrotoluene & 55.9 & 43.0 & 70.2 & & & & $56.4 \pm 13.6$ & 24.1 \\
\hline 4-Bromopheny 1 -pheny 1 ether & & & & 70.5 & 64.1 & 81.0 & $71.9 \pm 8.5$ & 11.9 \\
\hline Di-N-Butylphthalate & 66.4 & 63.8 & 71.8 & & & & $67.3 \pm 4.1$ & 6.1 \\
\hline Bis (2-Ethylhexy1) phthalate & 83.8 & 78.9 & 94.5 & & & & $85.7 \pm 8.0$ & 9.3 \\
\hline
\end{tabular}

(a) Recoveries are expressed in percent. Approximately $10 \mu \mathrm{g}$ of each component were added to the top of one-inch by nine-inch XAD-2 columns.

(b) These two compounds co-eluted.

$3,3^{\prime}$-Dichlorobenzidene and Benzo(b)fluoranthene were not recovered. (See Text) 
from quantitated gas chromatograms obtained before and after the particular step or steps under study. Two of the components in the mixture $\left(3,3^{\prime}-\right.$ Dichlorobenzidine) and benzo(b)fluoranthene were not recovered because their retention times in the gas chromatographic column were longer than the standard run time used in all our analyses. One component, 4-Bromophenyl-phenyl ether, eluted from the chromatographic column, gave satisfactory recoveries for two of the studies but could not be recovered either before or after the separation step in two other cases. Since the analytical conditions were identical in all these studies, it is difficult to propose a satisfactory rationale for this phenomenon.

Substantial evaporative losses occurred when ether samples were evaporated with a stream of dry nitrogen. However, boiling the ether off through Snyder "bubblecap" columns gave satisfactory recoveries ranging from 82.0 to 111.0 percent (Table 4). Recoveries from the gel permeation step were also satisfactory (Table 5) ranging from 81.2 to 90.3 percent with the exception of Bis(2-Ethylhexyl)phthalate, which averaged $120 \%$. This higher value, together with the $111 \%$ from Table 4 probably reflects some contamination of the sample with this component during the procedure. Since phthalates are ubiquitous plasticizers, such contamination is not surprising. Recoveries from silica gel (Table 6) were somewhat lower, ranging from 68.3-80.9\% (Bis(2-Ethylhexy1)phthalate was again higher at $90.5 \%$ ).

Table 7 1ists the overall recoveries from compounds added to the top of XAD-2 columns used for environmental sampling. The overall recoveries averaged somewhat higher than would be predicted from the individual recovery studies, but the coefficient of variations for the recoveries of individual components were in general higher, as might be expected.

These results have provided some assurance that microgram quantities of neutral components adsorbed on the XAD-2 column are recoverable to about $5 D-70 \%$. The extensive work by Junk, et al. (1974) has shown that trace levels of non-polar and moderately polar compounds are adsorbed from water onto XAD-2 resin with about $90 \%$ efficiency under the conditions used for sampling. Thus, we feel that trace quantities of non-polar or moderately polar (and hence lipophilic) products of chlorination of natural waters can be recovered adequately with the adsorption and separation techniques used for these studies.

\subsection{Haloform Analysis of XAD-2 Extracts}

The gas chromatographic method described for the analysis of XAD-2 ether extracts described in Section 3.2 was applied to all large volume samples as well as those XAD-2 samples specifically collected for haloform analyses. Concentrations of individual haloforms in ether extracts from XAD-2 samples ranged over two orders of magnitude. A typical chromatogram obtained from this analysis is given in Figure 7. Investigation of the value of the internal standard constant, $K$, for each component as a function of component concentration gave the curves in Figure 10. Theory predicts horizontal lines (i.e., $K=$ constant). Note in the figure that instrument integration parameter settings were important in obtaining accurate area measurements at low bromoform concentrations. Bromoform 


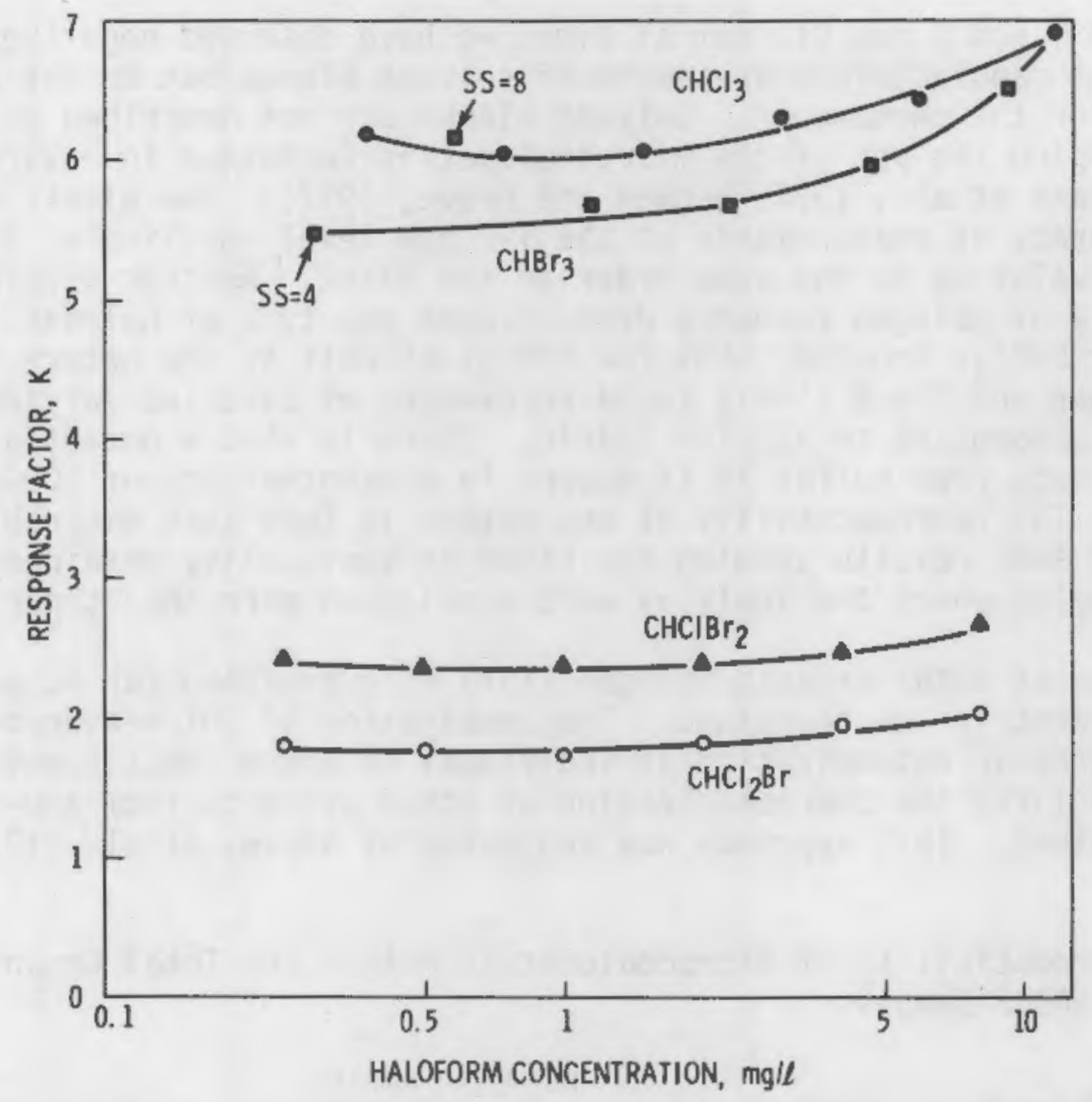

FIGURE 10. Relative Response Factors for Electron Capture Analysis of XAD-2 Extracts. Slope sensitivities (SS) were all 8 for the analysis except for the lowest concentrations of $\mathrm{CHBr}_{3}$.

retention time was sufficiently long to generate peaks which were broad with respect to height and thus a more sensitive slope sensitivity was required at low concentrations.

Figure 10 shows that a slope sensitivity (SS) of 8 does not give proper integration at low concentrations of $\mathrm{CHBr}_{3}$. Analytical reproducibility for all components was within $5 \%$, generally well within $2 \%$, for all concentrations with the exception of the lowest concentration of bromoform studied, where the reproducibility was only about $\pm 20 \%$ at $0.29 \mu \mathrm{g} / \ell$. The curves presented in Figure 10 were used to select the internal standard constant K most appropriate for the analete concentrations.

\subsection{Total Organic Halogen by Microcoulometry}

Experience with the microcoulometer has revealed some problems and limitations. The effort required to maintain optimal instrument performance seems to be excessive. Organic solvents give positive readings in the absence of added chlorine. The value of the solvent blank depends upon the type of solvent as well as other variables which we do not as yet understand. Values of blanks 
range between 1 and $2 \mathrm{ppm} \mathrm{Cl}$, but at times we have observed negative responses. The instrument manufacturers are aware of solvent blanks but do not have an explanation for the phenomenon. Solvent blanks are not described in two papers discussing the use of the microcoulometric technique in environmental chemistry (Glaze et al., 1977; Wegman and Greve, 1977). The blanks we obtain make the accuracy of measurements at the 1-2 ppm level unreliable, since the experimental value is on the same order as the blank. Another problem is that the efficiency of halogen recovery depends upon the type of halogen (chlorine, 80 to $90 \%$ for $\mathrm{CHCl}_{3}$; bromine, $\sim 50 \%$ for $\mathrm{CHBr}_{3}$ ) as well as the nature of the component. Wegman and Greve (1977) found recoveries of chlorine varying between $56 \%$ for dichloropropane to $92 \%$ for Aldrin. There is also a potential problem with interference from sulfur if it occurs in concentrations of 100-fold over the halogen. The reproducibility of the method is less than desirable.

Table 8 gives some results showing the range of variability obtained from environmental samples where the analyses were replicated more than three times.

The advantages of total organic halogen (TOX) determination far outweigh the problems inherent in the technique. The combination of Tox measurements with gas chromatographic determination of individual haloform constituents provides a valuable tool for the characterization of ether extracts from XAD-2 samples of natural waters. This approach was suggested by Glaze, et al. (1977).

TABLE 8. Reproducibility of Microcoulometric Method for Total Organic Chlorine in XAD-2 Samples

\begin{tabular}{|c|c|c|c|c|}
\hline Solvent & Date & $\underline{n}$ & $\begin{array}{c}\mu g / m \ell \text { in sample } \\
\bar{x} \pm \mathrm{s.d} \\
\end{array}$ & $v(\%)$ \\
\hline \multirow[t]{4}{*}{ Benzene } & $1 / 31 / 79$ & 4 & $295.56 \pm 2.50$ & 0.84 \\
\hline & $1 / 31 / 79$ & 5 & $1.64 \pm 0.31$ & 18.90 \\
\hline & $4 / 12 / 79$ & 4 & $2.07 \pm 0.20$ & 9.66 \\
\hline & $4 / 18 / 79$ & 4 & $43.15 \pm 2.69$ & 6.23 \\
\hline \multirow[t]{6}{*}{ Heptane } & $1 / 31 / 79$ & 4 & $44.39 \pm 2.09$ & 4.71 \\
\hline & $2 / 01 / 79$ & 4 & $77.40 \pm 4.34$ & 5.61 \\
\hline & $2 / 16 / 79$ & 4 & $53.14 \pm 7.65$ & 14.40 \\
\hline & $2 / 16 / 79$ & 5 & $4.84 \pm 0.13$ & 2.69 \\
\hline & $3 / 22 / 79$ & 4 & $98: 64 \pm 5.13$ & 5.20 \\
\hline & $4 / 26 / 79$ & 4 & $232.20 \pm 12.60$ & 5.43 \\
\hline \multirow[t]{4}{*}{ Ether } & $2 / 09 / 79$ & 4 & $6.42 \pm 0.67$ & 10.44 \\
\hline & $3 / 12 / 79$ & 4 & $11.11 \pm 1.04$ & 9.37 \\
\hline & $5 / 10 / 79$ & 4 & $10.84 \pm 1.10$ & 10.15 \\
\hline & $5 / 10 / 79$ & 4 & $4.81 \pm 0.19$ & 3.95 \\
\hline \multirow[t]{2}{*}{ Methanol } & $6 / 15 / 79$ & 4 & $6.19 \pm 0.17$ & 2.75 \\
\hline & & & & $7.36 \pm 4$. \\
\hline
\end{tabular}


The difference between the two types analyses (TOX less Total Haloforms) provide a measure of the non-haloform organohalogen constituents trapped on the $X A D$ resin that are extractable into ether. Further, the total organic halogen measurements on fractions either separated by molecular weight or by polarity can be used to determine which fractions contain important concentrations of organic chlorine.

\subsection{Anion Analysis by Ion Chromatography}

Samples were run using the anion concentrator column. For river waters, a sample size of $3 \mathrm{ml}$ was used as a compromise between desired increased sensitivity, loading ease, and concentrator column capacity (the 100-fold dilutions were used for the seawater samples). Since $F$ elutes approximately at the void volume, passing the $3 \mathrm{me}$ sample size through the concentrator column results in the nearly total elution of that anion. $\mathrm{Cl}^{-}$is only weakly bound to the resin, and therefore is subject to partial loss due to this self-elution at higher $\mathrm{Cl}^{-}$concentrations. A high concentration of one or more of the strongly bound anions tends to cause decreased recovery of the less strongly bound anions as the concentration of $\mathrm{SO}_{4}{ }^{2-}$ would result in partial loss of $\mathrm{Br}^{-}$. Since $\mathrm{NO}_{3}^{-}$ elutes very shortly after $\mathrm{Br}^{-}$, and the $\mathrm{NO}_{3}{ }^{-}$concentration in river waters can be determined by the direct injection method, the percent loss of $\mathrm{Br}^{-}$due to high $\mathrm{SO}_{4}{ }^{2-}$ levels approximates the percent loss of $\mathrm{NO}_{3}{ }^{-}$. The $\mathrm{Br}^{-}$results determined by use of the concentrator column were therefore adjusted by this "nitrate recovery factor."

While the use of a nitrate recovery factor as a linear correction factor on $\mathrm{Br}^{-}$ determinations is simplistic, it does provide a reasonable $\mathrm{Br}^{-}$estimate. In laboratory tests using standard solutions, $\mathrm{Br}^{-}$and $\mathrm{NO}_{3}{ }^{-}$peak heights both decreased with increasing $\mathrm{SO}_{4} 2$ - concentrations and to a lesser extent with increasing $\mathrm{Cl}^{-}$concentratons, but the effects were not identical. However, for the levels of $\mathrm{Br}^{-}$and $\mathrm{NO}_{3}{ }^{-}$observed, the linear correlation between $\mathrm{Br}^{-}$and $\mathrm{NO}_{3}{ }^{-}$recovery was reasonable for most river samples. High $504^{-}$concentrations in the Missouri and Ohio Rivers did cause drastic loss of recovery of $\mathrm{Br}$ " and $\mathrm{NO}_{3}{ }^{-}$from the anion concentrator columns. $\mathrm{Br}^{-}$values for these rivers are therefore highly dependent on the nitrate recovery factor as described above. In these two extreme cases, the reported $\mathrm{Br}^{-}$values are estimated to be low by no more than a factor of 2 due to the use of the $\mathrm{NO}_{3}$ - recovery factor.

Low $\mathrm{Br}^{-}$recovery was also observed in seawater samples when analyzed using the concentrator column. $\mathrm{Br}^{-}$values for these samples were most accurately determined using the sample loop. 



\section{ANALYSIS OF CHLORINATED NATURAL WATERS: RESULTS AND DISCUSSION}

\subsection{Volatile Components}

Data on volatile components was generated primarily using the purge-and-trap (P\&T) technique, since the method is suitable for the identification and quantification of many important volatile toxic organic chemicals, including twentythree compounds listed by the Environmental Protection Agency as priority polutants. At locations where chloroform was the major volatile constituent formed from water chlorination, the headspace technique was used as an additional method for chloroform analysis. Purge-and-trap samples were not taken at the Sequim, Wa, location. Bromoform concentration was determined at that salt water station using the XAD-2 adsorption technique.

The results of the P\&T analysis for nine stations are presented in Table 9. The data are arranged such that the results for the chlorinated water samples are presented at the upper left-hand corner of each box, and the results for the corresponding unchlorinated control are presented in the lower righthand corner of the same box. For example, the concentration of chloroform found in Columbia River water chlorinated at $2.7-3.0 \mathrm{mg} / \ell$ was 12.0 and $13.5 \mu \mathrm{g} / \mathrm{l}$ for duplicate samples; the corresponding unchlorinated contro] contained only traces of $\mathrm{CHCl3}_{3}$. The data is presented in this format so that component concentrations can be readily compared on a station by station basis by scanning vertically down the upper left hand corner results for any individual component listed. Similarly, information about all components identified at any one station can be easily compared by scanning horizontally across the upper left hand corners of the boxes corresponding to the station of interest. Comparison of any chlorinated value with corresponding control is performed by glancing diagonally across a box.

In addition to the haloforms, dichloromethane and carbon disulfide were found in almost all P\&T samples investigated; hence these components were added to the components used to generate the calibration data (Figure 9). For most stations, the concentrations of dichloromethane were similar in both chlorinated and control water, although the concentrations were significantly higher at two stations (L. Michigan and San Onofre). Carbon disulfide was found to be present at $>20 \mu \mathrm{g} / 2$ in samples from seven out of nine of the nine stations investigated. It is difficult to decide whether this result reflects actual environmental concentrations in natural waters. It is possible that CS2 may be a containment in the septa used to seal the bottles; however, $\mathrm{CS}_{2}$ was not found in the sample from San Onofre. Since the CS2 content of the samples did not appear to be related to the chlorination process, controlled experiments to determine whether the $\mathrm{CS}_{2}$ was a contamination phenomenon were not pursued.

As reported by many workers, haloforms are found to be the principle volatile products arising from the chlorination of natural waters. The data presented in Table 9 are in complete agreement with these findings. The waters containing significant quantities of sea water (Cape Fear, 50\% seawater; San Onofre, 100\%) produced primarily bromoform, consistent with previous observations (Carpenter, 1978; Bean et a 1, 1979; Helz, 1979). The concentrations of haloforms varied widely among locations, however. Chloroform production at fresh water locations 
TABLE 9. Concentrations of Volatile Organics in Natural Waters as Analyzed by the "Purge and Trap" Method (concentrations are reported in milograms per Titer)

\begin{tabular}{|c|c|c|c|c|c|c|c|c|c|c|}
\hline $\begin{array}{l}\text { STATION } \\
\text { (DATE) (CI ADDED mg/l) }\end{array}$ & & $\begin{array}{l}\text { PICHLORO } \\
\text { METHANE }\end{array}$ & $\begin{array}{l}\text { CARBON } \\
\text { DISULFIDE }\end{array}$ & $\mathrm{CHCl}_{3}$ & $\mathrm{CHCl}_{2} \mathrm{Br}$ & $\mathrm{CHClBr}{ }_{2}$ & $\mathrm{CHBr}_{3}$ & $\begin{array}{l}\text { OICHLORO } \\
\text { ETHYLENE }\end{array}$ & $\begin{array}{l}\text { TRICHLORO } \\
\text { ETHYLENE }\end{array}$ & TOLUENE \\
\hline $\begin{array}{l}\text { 1. COLUMBIA R. (WA) } \\
(5 / 79)(2.7-3.0)\end{array}$ & $\begin{array}{ll}\mathrm{Cl} \\
\mathrm{N}\end{array}$ & 1 & 720 & $\begin{array}{r}12.0 .13 .5 \\
\square\end{array}$ & - & - & - & - & $*$ & ++ \\
\hline $\begin{array}{l}\text { 3. OHIO R (WV) } \\
(8 / 78)(4.0-5.3)\end{array}$ & $\mathrm{Cl}$ & 11 & $\begin{array}{r}>20,>20 \\
>20 \\
\end{array}$ & $\begin{array}{|rr|}7.3 .5,7 & \\
& 0.6 \\
\end{array}$ & 3.4.3.1 & $0.9,0.9$ & - & 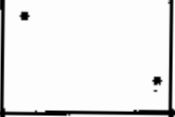 & - & $t$ \\
\hline $\begin{array}{l}\text { 4. L. MICHIGAN (MI) } \\
(8 / 78)(3.0-3.8)\end{array}$ & $\mathrm{NI}$ & 17,14 & $\begin{array}{r}>20 .>20 \\
\end{array}$ & 2.7 .2 .0 & 18.1 .6 & 0.8 .0 .5 & - & - & - & $\pi$ \\
\hline $\begin{array}{l}\text { 5. MISSOURI R. (MO) } \\
(9 / 78)(3.6-4.8)\end{array}$ & $\mathrm{CI}$ & 15 & $>20$ & 11.5 & 10.3 & 5.8 & - & - & - & tr \\
\hline $\begin{array}{l}\text { 6. TENNESSEE R. (KY) } \\
(9 / 78)(4.3-4.7)\end{array}$ & $\mathrm{Cl}$ & \begin{tabular}{rr|}
17,17 & \\
& 13 \\
\end{tabular} & $\begin{array}{r}>20>20 \\
>20 \\
\end{array}$ & $\begin{array}{r}21.2 .24 .7 \\
t r \\
\end{array}$ & 6.0 .7 .4 & $\begin{array}{r}1.1 .1 .1 \\
\quad- \\
\end{array}$ & * & - & - & $\pi$ \\
\hline $\begin{array}{l}\text { 7. CAPE FEAR (NC) } \\
(10 / 78)(4.8-5.7)\end{array}$ & $\mathrm{Cl}$ & 1,3 & $\begin{array}{rr}12,10 & \\
& >20 \\
\end{array}$ & tr & 19.2 .6 & $\begin{array}{r}15.7 .17 .8 \\
- \\
\end{array}$ & $54.5 \ddagger$ & - & - & ++ \\
\hline $\begin{array}{l}\text { B. L. NORMAN (NC) } \\
(10 / 78)(4.1)\end{array}$ & $\mathrm{Cl}$ & 3,4 & $\begin{array}{r}>20.19 \\
\\
\quad>20 \\
\end{array}$ & 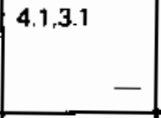 & $\begin{array}{r}1.7 .1 .4 \\
\quad- \\
\end{array}$ & - & - & -1 & - & ++ \\
\hline $\begin{array}{l}\text { 9. CONNECTICUT R. (CT) } \\
(10 / 78)(4.3-5.0)\end{array}$ & $\mathrm{N}$ & 1 & $>20$ & $\begin{array}{r}18.7,24.5 \\
\pi \\
\end{array}$ & $2.3,3.4$ & - & - & - & - & ++ \\
\hline $\begin{array}{l}\text { 10. SAN ONOFRE (CA) } \\
(2 / 79)(2.9-3.2)\end{array}$ & $\mathrm{Cl}$ & 6 & - & - & - & tr & $\begin{array}{r}13.0,17.0 \\
-\end{array}$ & - & $*$ & t+ \\
\hline
\end{tabular}

\footnotetext{
$-\quad=$ not detected

$\mathrm{tr}=$ trace (present in concentrations less than $0.5 \mu \mathrm{g} / \mathrm{Q}$ )

* = shown to be present in single ion reconstructed chromatogram

$++=$ present at the several $\mu g / \ell$ level

$\ddagger=$ analyzed using XAD-2 method
} 
varied from $2 \mu \mathrm{g} / \mathrm{l}$ ( $\mathrm{L}$. Michigan) to $25 \mu \mathrm{g} / \mathrm{\ell}$ (Tennessee R.). Traces of chloroform were found in seven of nine control waters.

Table 10 gives comparative results obtained for chloroform analysis by both P\&T and headspace methods. It will be recalled that sampling points in the chlorination apparatus were different for the two methods; the headspace sample was withdrawn from the chlorination chamber, while the P\&T sample was taken from the sampling chamber after sulfite and acid had been added with stirring. Thus, from the results in Table 3 , one would expect values from the purge-and-trap analysis to be at least 10\% lower. The chloroform values reported for the headspace method are higher than the corresponding P\&T values, with the exceptions of the Tennessee River where the reverse is true, and the Missouri River, where the values were essentially the same. The agreement in quantitative results obtained between the two quite different sampling and analytical methods at the stations investigated gives additional assurance that the values obtained for the haloform analyses are reasonably accurate.

IABLE 10. Comparison of Chloroform Analyses by Purge-and-Trap Technigue with Headspace Technique (concentrations reported at $\mu g / \ell$ ) $(a)$

\begin{tabular}{|c|c|c|c|c|}
\hline \multirow[b]{2}{*}{ Station } & \multicolumn{2}{|c|}{ Chlorinated } & \multicolumn{2}{|c|}{ Nonclorinated } \\
\hline & Headspace & $\bar{P}+T$ & Headspace & $P+T$ \\
\hline 1. Columbia R. & $14.0 \pm 0.8$ & $13.5 \pm 1.0$ & $1.2 \pm 0.1$ & $\operatorname{tr}$ \\
\hline 3. Ohio R. & 7.2 & $6.5 \pm 0.8$ & $1.5 \pm 0.3^{\star}$ & $\operatorname{tr}(b)$ \\
\hline 4. L. Michigan & $4.6 \pm 0.2^{\star}$ & $2.4 \pm 0.4$ & $1.0 \pm 0.1^{\star}$ & $\operatorname{tr}$ \\
\hline 5. Missouri R. & $10.4 \pm 1.3$ & 11.5 & $2.3 \pm 0.3$ & $\operatorname{tr}$ \\
\hline 6. Jennessee $R$. & $16.6 \pm 0.4$ & $23.0 \pm 1.8$ & $2.3 \pm 0.2$ & $\operatorname{tr}$ \\
\hline 7. Cape Fear & 4.1 & $\operatorname{tr}$ & 1.8 & $\operatorname{tr}$ \\
\hline 8. L. Norman & $7.7 \pm 0.2$ & $3.6 \pm 0.5$ & $1.7 \pm 0.0$ & nd \\
\hline 9. Connecticut $R$. & $25.9 \pm 2.3$ & $21.6 \pm 2.9$ & $1.3 \pm 0.5$ & $\operatorname{tr}$ \\
\hline 10. San Onofre B. & $0.4 \pm 0.0^{\star}$ & $n d^{(c)}$ & $\operatorname{tr}$ & nd \\
\hline
\end{tabular}

(a) Headspace samples were sampled in triplicate and the sample variation reported as \pm Standard Deviation except for those values with an asterisk, where duplicates were analyzed and the variation reported as a range. Purge and trap samples were analyzed in duplicate where possible, and the variation reported as a range.

(b) $\mathrm{tr}=$ trace (present in concentrations less than $0.5 \mu \mathrm{g} / 1$ )

(c) nd $=$ not detected 
Not only was there wide variation in the total quantity of haloforms produced at different locations, there also was a wide spectrum of product distribution. For example, in Table 9, the Columbia River sample consisted almost exclusively of chloroform, with a trace of bromodichloromethane, and no evidence of other haloform species. In contrast, another fresh water sample, from the Missouri River contained almost as much of the monobromo species $(10.3 \mu \mathrm{g} / \ell)$ as it did chloroform $(11.5 \mathrm{\mu g} / 2)$, with significant quantities of the dibromo species $(5.8 \mu \mathrm{g} / \mathrm{l})$. Helz (1979) has shown a direct relationship between the seawater content of estuarine water and the relative quantity of bromine incorporated into the haloforms produced by chlorination. Since sea water contains about $65 \mathrm{mg} / \ell$ bromide, it is not surprising that small quantities of sea water can produce quantities of relatively large organobromine compounds, since bromide ion is easily oxidized to bromine by chlorine in aqueous solution. Both Minear (1980) and 01 iver (1980) have shown the relationship between the bromide ion content of natural waters and the production of bromine-containing haloforms from chlorination of these waters. Table 11 shows the principal anionic species found to be present in water obtained from nine of the ten stations sampled. A comparison of the bromide ion concentrations in Table 11 with the haloform distributions given in Table 9 reveals a good correlation between the bromide ion concentration found and the relative abundance of bromine in the haloforms produced during chlorination. Both the Missouri and Ohio Rivers were found to contain about 80 and $70 \mu \mathrm{g} / \mathrm{l}$ bromide ion; and the contribution of bromodichloromethane to the total haloform produced is substantial. The Columbia River contained only about $4 \mu \mathrm{g} / 2$ bromide ion, and very little bromide contribution to total haloforms is observed.

TABLE 11. Anionic Species Present in River and Sea Water Samples

\begin{tabular}{|c|c|c|c|c|c|c|c|}
\hline Station & $\begin{array}{l}\text { Sampling } \\
\text { Oate }\end{array}$ & $\mathrm{Cl}^{-}$. & $\mathrm{Br}^{-}$ & $\mathrm{SO}_{4}^{-}$ & $\mathrm{NO}_{3}^{-}$ & $\mathrm{F}^{-}$ & $\mathrm{PO}_{4}^{3-}$ \\
\hline 1. Columbia R. & $4-10-79$ & 1 & 0.004 & 12 & 0.4 & 0.1 & $\leq 0.03$ \\
\hline 2. Sequim B & $8-9-78$ & & & & & & \\
\hline $10: 00$ (tide out) & & 17480 & 55 & 2300 & $\leq 1$ & 2 & $\leq 3$ \\
\hline 15:00 (tide in) & & 17080 & 53 & 2260 & $\leq 2$ & 2 & $\leq 2$ \\
\hline 3. Ohio R. & $8-17-78$ & 28 & 0.07 & 218 & 5 & 0.3 & $\leq 0.2$ \\
\hline 5. Missouri R. & $9-8-78$ & 17 & 0.08 & 176 & 1 & 0.4 & 0.2 \\
\hline 6. Tennessee R. & $9-10-78$ & 6 & 0.03 & 140.3 & 0.1 & & $\leq 0.7$ \\
\hline 7. Cape Fear & $10-14-78$ & 8260 & 26 & 1030 & $\leq 3$ & $n d^{(a)}$ & $\leq 0.6$ \\
\hline 8. L. Norman & $10-16-78$ & 3 & 0.02 & 4 & 0.3 & 0.1 & $\leq 0.03$ \\
\hline 9. Connecticut R. & $10-20-78$ & 13 & 0.03 & 13 & 2 & 0.7 & 0.4 \\
\hline 10. San Onofre & $2-28-78$ & 19150 & 54 & 2440 & $\leq 2$ & nd & $\leq 2$ \\
\hline
\end{tabular}

(a) nd--not determined 
A major observation to be made about the waters sampled and analysed by P\&T is that they were remarkably free from contamination by volatile non-haloform organic compounds. Although each GC/MS run was searched using single ion reconstruction technique for al1 of the 23 priority pollutants, Table 9 lists a 11 of the compounds actually found in the samples which were not found in procedural blanks. Traces of di- and trichloroethylene were found in some samples, but not in any significant quantity or pattern which might indicate their formation as a consequence of chlorination. Comparability of toluene concentrations between chlorinated sample and control, and the consistency with which it was found in all samples suggests that it was present as a contaminant in the sampling apparatus.

The concentrations of haloforms found in our studies should be placed in context with other processes involving chlorination. Chlorine treatments of drinking water and of waste waters are common disinfection practices. Chlorine doses used for these purposes are often substantially higher than used for biofouling control. Ohio river water when treated with $10 \mathrm{mg} / \ell$ chlorine was found to produce chloroform concentrations between 100 and $200 \mu \mathrm{g} / \mathrm{l}$ after 24 hours (Rickabaugh and Kinman, 1978). Similar concentrations of chloroform were found in the water of a major Virginia drinking water distribution systerl in 1975 (Hoen, et al., 1978), although the average chloroform concentration in the drinking waters of eighty U.S. cities was reported to be $21 \mu \mathrm{g} / \mathrm{h}$ (Sonneborn and Bohn, 1978). Waste water chlorination levels can be higher than those used for drinking water, often exceeding $10 \mathrm{mg} / \ell$ and occasionally rising as high as $50 \mathrm{mg} / \mathrm{l}$ (Howland and Wallace, 1978). Thus, although in many cases additional treatment of the chlorinated waters reduces the quantity of chloroform produced by chlorination of drinking and waste waters, the levels of chloroform in waste waters and in ordinary domestic water can be at least as high and of ten greatly exceed those found in our studies.

\subsection{XAD-2 Samples: Ha loforms and Organic Ha logen Analyses}

A primary task in the analysis of the XAD-2 samples was to determine the quantity of non-haloform organic halogen adsorbed on the XAD resin columns. This was accomplished by analyzing the ether extracts for tota1 organic halogen (TOX) by microcoulometry and for total haloforms by electron capture gas chromatography. The halogen present in the sample as haloform halogen is then subtracted from the Tox to yield the value for non-haloform halogen. This procedure closely follows that reported by Glaze, et a1. (1977).

The results of the analyses obtained from the ten locations studied are in Table 12. For all stations, samples were collected on XAD-2 columns connected in series. The top control column, and the top and bottom chlorinated water columns were analysed for haloforms and TOX. For six stations, duplicate sets of top and bottom chlorination samples were analysed. As in the case of the bromoform analysis procedures (see Section 4), analys is of columns in series was performed in order to investigate the efficiency of adsorption of halogenated material.

The data in Table 12 demonstrate the poor recovery of chloroform from water under the sampling conditions used, since values for chloroform from top and 
bottom columns are quite similar. This would be predicted from the data in Table 2 which indicate only about 10\% recovery of chloroform. As has been previously pointed out (Table 1), bromoform is trapped much more efficientiy. Comparison of data obtained for top and bottom columns did not give the information about trapping efficiencies for non-haloform components we hoped to obtain. If non-haloform components were trapped much more efficiently than chloroform, then the percent total halogen as chloroform in the bottom columns should be much higher for the fresh water stations. The data for fresh water stations does not show a trend of this type; in fact, the reverse was found to be the case (higher percent haloform halogen in the top column) for most of the sample pairs obtained for the fresh water. For all salt water stations the quantity of non-haloform bromine in the top column was substantially higher than in the bottom column, indicating that the bulk of the non-haloform organobromine was trapped by the XAD-2 resin columns from the seawater systems.

An observation which stands out clearly from the data on Table 12 is that the haloforms in al1 cases are the principal source of organic halogen trapped on the XAD-2 resins. Since in the case of fresh water the efficiency of chloroform absorption under the sampling conditions was only about $10 \%$ (Table 2), it appears very likely that haloforms constitute the principal lower molecular weight, lipophilic halogenated species formed from the low level chlorination of both fresh and saline natural waters. This result, although not conclusive when based on the data in Table 12 (and Table 9), is investigated further in the next section dealing with the fractionation of the ether extracts. Another observation which can be made from iable 12 is that methods for analys is of TOX in water which rely on adsorption of matter onto XAD-2 resins, such as that reported by GTaze (1977), are in need of further investigation regarding efficiency of the adsorption medium. For the purposes of these investigations, XAD- 2 resins are adequate for collection of the lipophilic chlorinated components of interest since their efficiency for these components has been demonstrated (Junk, 1974); however, very hydrophilic components may adsorb poorly on XAD-2 and thus not be included in a TOX method using these resins.

\subsection{XAD-2 Samples: Analys is of Fractions for Total Organic Halogen}

Fractions obtained from the XAD-2 ether extracts were analyzed routinely for organic halogen using the microcoulometric method. These results, expressed as nanomoles of halogen per liter of water sampled are given in Table 13. Values given in Table 13 are not corrected for recoveries. The first column gives the TOX in the ether extract prior to evaporation and is derived from the Tox data on Table 12. The next column gives the ToX in the evaporated sample after changing to benzene. Note that for the fresh water stations, there are considerable losses in halogen resulting from the evaporation step; this can be attributed to losses of volatile chloroform. For the marine samples, losses are generally not as great as with the fresh water samples since bromoform is less volatile. Two samples from Station 10 (San Onofre) gave lower TOX values for the ether extracts than for the evaporated sample. We cannot 
account for this; the other data appears to be consistent with evaporation of haloform during sample concentration.

The data on Table 13 is difficult to digest or interpret, since so many variables are represented (ten stations, chlorinated and control samples, replication, and top and bottom columns). However, before examining the data in another format, a few comments should be made. The data are based on triplicate analyses of the organic halogen in the fractions by microcoulometry and consist of the average + standard deviation. Variation was usually within $10 \%$ although there are exceptions.

It will be seen from inspection of Table 13 that in only one instance was any organic chlorine found in the higher molecular weight fractions. The gel permeation procedure was instituted in order to remove high mole weight materials which appeared to interfere with the gas chromatographic analysis of the ether extracts. It seems that little if any chlorinated material of mole weight greater than 800 is present in the ether extracts. Comparison of the weights of selected evaporated residues with those of solvent blanks indicated that little, if any material was actually present in these fractions. The procedure was continued throughout the course of the program in order to maintain consistency of analytical results; however in view of the absence of chlorine in these fractions, further work with XAD-2 extracts in the future can undoubtedly be conducted without the use of the gel permeation step.

The quantity of halogen found in the fraction $<800$ molecular weight was consistently less than that present in the evaporated sample prior to the GPC procedure. In general, the losses are more than can be accounted for by the recovery studies (Table 5) which indicate losses no greater than $20 \%$ as a result of the GPC step. These losses are therefore interpreted to be largeiy due to volatilization of remaining haloform in addition to mechanical losses. Since the preparation of the $<800$ mole weight fraction requires evaporation of a considerable quantity of benzene, it is believed that most of the additionai haloform has been removed from the sample by this step, and that the organic halogen analys is is a fair representation of the non-haloform organohalogen remaining in the sample.

The data on Table 13 have been reorganized into another format which allows better inspection of the data with respect to the variables studied. Tables 14 and 15 are arranged in a manner similar to Table 9 . The results are not reported on a molar basis as in Table 13, but are expressed in $\mu \mathrm{g} / \mathrm{l}$ chlorine. Regardless of the actual halogen present in the sample, all the numbers are in terms of equivalent weight of chlorine. The $\mu \mathrm{g} / \mathrm{l}$ equivalent chlorine found in any one fraction can then be directly compared to the $\mathrm{mg} / \mathrm{l}$ chiorine originaliy added to the water (aTso given in Tables 14 and 15) to give a measure of the relative quantity of added chlorine used to form the organochlorine found in the sample.

In Table 14 the upper left hand corner of each box gives the value of the chlorinated sample and the lower right hand corner the value for the corresponding control. The data on this table gives values derived only from the 
TABLE 12. Comparison of Ha Toform Content in XAO-2 Extracts with Total Organic Halogen

\begin{tabular}{|c|c|c|c|c|c|c|c|}
\hline $\begin{array}{c}\text { Sample } \\
\text { (Date) }(C 1 \text { Added } \\
\mu \mathrm{mg} / \mathrm{\ell})\end{array}$ & $\begin{array}{l}\mathrm{CHCl}_{3} \\
(\mu \mathrm{g} / \mathrm{l})\end{array}$ & $\begin{array}{l}\mathrm{CHCl}_{2} \mathrm{Br} \\
(\mu \mathrm{g} / \mathrm{B})\end{array}$ & $\begin{array}{l}\text { CHClBr2 } \\
(\mu \mathrm{g} / \mathrm{e})\end{array}$ & $\begin{array}{l}\mathrm{CHBr}_{3} \\
(\mu \mathrm{g} / \mathrm{l})\end{array}$ & $\begin{array}{c}\text { nMole } x \\
\text { per liter } \\
\text { as Haloform }\end{array}$ & $\begin{array}{r}\text { nMole } x \\
\text { per liter } \\
\text { Microcoulometer }\end{array}$ & $\begin{array}{l}\text { \% Halogen as } \\
\text { Haloform in } \\
\text { Chlorinated } \\
\text { Sample } \\
\end{array}$ \\
\hline
\end{tabular}

1.Columbia R. (WA)

$(5 / 79)(2.7-3.0)$

Control Top A

Chlorinated Top A

0.03 nd

$\begin{array}{ll}0.03 & \text { nd } \\ 2.26 & 0.22\end{array}$

nd

Chlorinated Bottom A

2.56

0.21

0.01

nd

nd

0.9

60.8

$2.9 \pm 1.9$

68.2

$80.3 \pm 3.9$

$84.2 \pm 7.1$

76

2. Sequim B. (WA)

$(8 / 78)(1.8)$

Control Top

Chlorinated Top

Chlorinated Bottom

$\begin{array}{ll}\text { nd } & \text { nd } \\ 0.06 & 0.03\end{array}$

$0.04 \quad 0.02$

nd

0.60

0.35

nd 11.13

nd

$12.7 \pm 4.3$

$143.4 \quad 235.8 \pm 14.3$

$\begin{array}{lll}4.23 & 56.6 & 60.0 \pm 0.2\end{array}$

61

3. Ohio R. (WV)

$(8 / 78)(4.0-5.3)$

Control Top A

Chlorinated Bottom A

Chlorinated TOD B

$\begin{array}{ll}0.04 & \text { nd } \\ 1.28 & 0.89\end{array}$

$\begin{array}{ll}1.28 & 0.89 \\ 1.37 & 1.02\end{array}$

$\begin{array}{ll}1.37 & 1.02 \\ 0.67 & 0.48\end{array}$

Chlorinated Bottom B

$1.00 \quad 0.36$

nd

0.61

0.47

0.47

0.30

nd
tr
nd
tr
0.04

0.9

57.3

59.9

32.5

$0.04 \quad 36.7$

$10.7 \pm 1.2$

$84.4 \pm 8.4$

$87.7 \pm 3.9$

$64.3 \pm 4.8$

$60.8 \pm 1.3$

68

68

51

4. L. Michigan (MI)

$(8 / 78)(3.0-3.8)$

Control TOP $A$

Chlorinated Top A

Chlorinated Bottom A

$\begin{array}{ll}0.91 & 0.88 \\ 0.72 & 0.74\end{array}$

0.72

$0.93 \quad 0.90$

0.67

0.35

Chlorinated Top B

$0.82 \quad 0.69$

0.64

tr

nd

48.6

$53.9 \pm 5.7$

$43.1 \pm 1.5$

$58.6 \pm 1.4$

49.0

$59.5 \pm 4.7$

93

$0.01 \quad 38.3$

85

Missouri R. (MO)

$(9 / 78)(3.6-4.8)$

Control TOP A

Chlorinated Top A

Chlorinated Bot tom A

Chiorinated Top B

nd nd

38.3

$25.3 \pm 3.7$

nd

nd

0.0

120.0

2.36
1.74

0.36

$2.24 \quad 1.97$

$3.31 \quad 2.58$

2.67

0.09

118.3

172.0

$\begin{aligned} 155.6 & \pm 6.7 \\ 40.7 & \pm 0.6\end{aligned}$

$183.8 \pm 6.8$

$190.5 \pm 8.6$

2.88

2.52

148.9

78 
6. Tennessee R. (KY)

$(9 / 78)(4.3-4.7)$

Control Top A

Chlorinated Top A

Chlorinated Bottom $A$

Chlorinated Top B

nd $3.31 \quad 1.54$

1.54

Chlorinated Bottom B

4.08

2.02

$4.69 \quad 1.55$

0.48

0.35

0.57

0.25

nd

nd

nd

nd

118.0

$32.7 \pm 3.7$

$172.1 \quad 190.9 \pm 4.1$

7. C. Fear (NC)

(10/78) (4.8-5.7)
Control Top A

Chlorinated Top A

nd nd

$0.05 \quad 0.70$

Chlorinated Bottorn $A$

0.05

0.32

nd

7.76

nd

149.7

$195.9 \pm 10.8$

66
79

90

8. L. Norman (NC)

(10/78) (4.1)

Control Top A

Chlorinated Top A

Chlorinated Bottom A

nd

nd

4.98

36.33

nd

556.6

306.6

$25.0 \pm 33.1$

$697.7 \pm 33.9$

$454.4 \pm 27.0$

Chlorinated Top B

2.20

1.22

2.20

1.03

0.54

nd

0.34

nd

0.71

0.96

0.31

0.12

no

0.17

0.0

$13.2 \pm 5.5$

42.1

$116.3 \pm 12.3$

$70.7 \pm 1.5$

$84.8 \pm 1.9$

$59.2 \pm 3.2$

68

46.3

60

9. Connecticut R. (CT)

(10/78) (4.3-5.0)

Control Top A

Chlortnated Top A

Chlorinated Bottom A

ChIorinated Top B

$\begin{array}{ll}0.07 & \text { nd } \\ 1.75 & 0.28\end{array}$

$\begin{array}{ll}1.75 & 0.28 \\ 3.37 & 0.53\end{array}$

Chiorinated Bottom 8

4.30

0.73

nd

0.02

0.04

0.05

0.04

0.04

nd

1.8

51.41

94.8

nd

123.9

nd

111.0

$27.5 \pm 3.6$

$60.3 \pm 3.7$

$155.1 \pm 8.8$

$177.3 \pm 6.5$

$146.1 \pm 6.6$

85

10. San Onofre (CA)

(2/79) (2.9-3.2)

Control Top A

Chlorinated Top A

Chlorinated Bottom A

nd nd

nd
0.02
0.02

$\begin{array}{ll}\text { nd } & \text { nd } \\ 0.40 & 15.29\end{array}$

nd
187.5
77.5

$1.8 \pm 1.5$

$247.1 \pm 20.4$

$100.8 \pm 5.3$

76
77 
TABLE 13. Analys is of XAD-2 Extracts and Fractions for Total Organic Halogen (Values expressed as nanomoles halogen per liter of water samples)

Sample
(Date)(Cl Added
$\mathrm{mg} / \mathrm{l})$

4. L. Michigan (MI) $(8 / 78)(3.0-3.8)$ Controi Top $A$ Chlorinated Top A Chlorinated Top B Chlorinated Botton B

5. Missouri R. (MO) $(9 / 78)(3.6-4.8)$ Control Top A Chlorinated Top A Chlorinated TOD B Chlorinated Bottom B

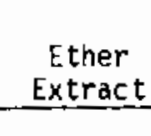

$5.3 \pm 1.9$ $85.2 \pm 3.9$ $86.3 \pm 7.1$

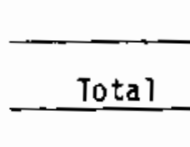

$$
>15,000 \mathrm{MW}
$$
5,000

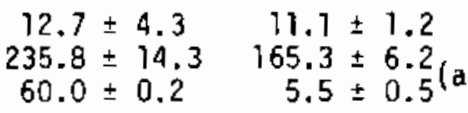

$11.1 \pm 1.2$ $65.3 \pm 6.2(a)$

nd
nd
nd

nd

nd

nd

$1.6 \pm 0.2$

$10.5 \pm 1.9$

$6.7 \pm 0.6$

$0.2 \pm 0.0 \quad 1.0 \pm 0.2 \quad 0.4 \pm 0.0$ $5.4 \pm 0.5 \quad 2.1 \pm 0.1 \quad 1.7 \pm 0.0$ $1.6 \pm 0.7 \quad 0.6 \pm 0.0$ nd

Silica Gel Fractions $80 / 20$ Hex/Ethe

Ether

$100 \%$

nd

nd

$2.4 \pm 0.2$ $41.4 \pm 2.3$

$1.0 \pm 0.1$

$0.5 \pm 0.0 \quad 0.8 \pm 0.0 \quad$ nd $\begin{array}{llll}0.5 \pm 0.5 & 0.4 \pm 0.1 & 1.0 \pm 0.2\end{array}$ $0.2 \pm 0.0 \quad 0.4 \pm 0.1 \quad 0.5 \pm 0.1$

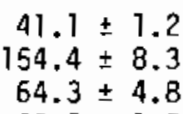

$41.1 \pm 1.2$ $154.4 \pm 8.3$ $64.3 \pm 4.8$ $60.8 \pm 1.3$

$9.5 \pm 0.2$ $52.4 \pm 0.4$ $41.2 \pm 1.3$ $24.2 \pm 0.6$

nd
nd
nd
nd

$5.0 \pm 0.2$ $13.7 \pm 1.5$ $17.5 \pm 0.4$

$6.7 \pm 0.2$

$1.3 \pm 0.0 \quad 1.7 \pm 0.3 \quad 0.3 \pm 0.3$ $2.1 \pm 0.0 \quad 1.9 \pm 0.0 \quad 0.5 \pm 0.3$ $3.9 \pm 0.4 \quad 2.0 \pm 0.1 \quad 2.5 \pm 0.5$ $1.8 \pm 0.1 \quad 1.9 \pm 0.0 \quad 0.4 \pm 0.4$

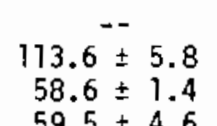

$59.5 \pm 4.6$

$5.7 \pm 0.1$ $42.6 \pm 1.8$ $30.8 \pm 0.7$

$24.6 \pm 0.6$

$\begin{array}{ll}\text { nd } & \text { nd } \\ 0.1 \pm 0.0 & 0.2 \pm 0.1 \\ \text { nd } & \text { nd } \\ \text { nd } & \text { nd }\end{array}$

$2.2 \pm 0.0$ $11.1 \pm 0.1$ $11.4 \pm 0.2$

$3.1 \pm 0.1$

$4.5 \pm 0.1$

$23.7 \pm 1.7$ $28.0 \pm 1.4$ $17.8 \pm 0.3$
$155.6 \pm 6.8$

$183.5 \pm 6.8$

$191.3 \pm 8.6$
114.4

$94.5 \pm 2.8$

nd

$0.6 \pm 0.0 \quad 0.7 \pm 0.0 \quad$ nd $2.8 \pm 0.1 \quad 1.8 \pm 0.1 \quad 0.2 \pm 0.0$ $3.1 \pm 0.1 \quad 1.2 \pm 0.1 \quad 0.4 \pm 0.0$ $0.7 \pm 0.0 \quad 0.6 \pm 0.1 \quad 0.3 \pm 0.0$

$1.2 \pm 0.1 \quad 2.0 \pm 0.0 \quad 0.9 \pm 0.0$ $5.7 \pm 0.8 \quad 8.9 \pm 0.62 .1 \pm 0.0$ $6.3 \pm 0.1 \quad 5.0 \pm 0.3 \quad 1.9 \pm 0.2$ $1.2 \pm 0.4 \quad 0.5 \pm 0.7 \quad 0.8 \pm 0.0$ 
6. Tennessee R. (KY)

$(9 / 78)(4.3-4.7)$

Control Top $A$

Chlorinated Top A

Chlorinated Top B

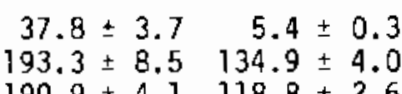

Chlorinated Bottom B

$200.7 \pm 10.478 .7 \pm 10.4$

$\begin{array}{ll}\text { nd } & \text { nd } \\ \text { nd } & \text { nd } \\ \text { nd } & \text { nd } \\ \text { nd } & \text { nd }\end{array}$

$3.4 \pm 0.1 \quad 1.6 \pm 0.0 \quad 0.8 \pm 0.1 \quad 1.8 \pm 0.1$ $35.8 \pm 1.4 \quad 30.0 \pm 0.4 \quad 11.3 \pm 1.1 \quad 6.1 \pm 0.1$ $36.0 \pm 2.0 \quad 5.8 \pm 0.210 .9 \pm 0.43 .9 \pm 0.4$

7. Cape Fear (NC)

$(10 / 78)(4.8-5.7)$

$8.3 \pm 0.4$

$1.1 \pm 0.13 .3 \pm 0.6 \quad 1.1 \pm 0.1$

Control Top A

Chlorinated Top A

$25.0 \pm 3.1 \quad 31.1 \pm 0.7$

$697.7 \pm 33.9329 .3 \pm 53.3$

$454.4 \pm 27.097 .8 \pm 16.9$

nd

Chlorinated Bottom A

8. L. Norman (NC)

$(10 / 78)(4.1)$

Control Top A

Chlorinated Top A

Chlorinated Top 8

$13.2 \pm 5.5 \quad 3.1 \pm 0.1$

$117.6 \pm 12.7 \quad 86.0 \pm 1.4$

$84.9+1.967 .4+4.9$ $\begin{array}{ll}84.9 \pm 1.9 & 67.4 \pm 4.9 \\ 59.1 \pm 3.2 & 36.0 \pm 2.0\end{array}$

nd
nd
nd
nd

no

9. Connecticut R. (CT)

$(10 / 78)(4.3-5.0)$

Control Top A

Chlorinated Top A
Chlorinated Bottom A

$27.5 \pm 3.6 \quad 8.3 \pm 0.3$

$177.5+8.1 \quad 105.9+1.3$

$146.8 \pm 6.6 \quad 87.0 \pm 4.1$

nd

nd

nd

nd

nd

$4.1 \pm 0.1$
$16.0 \pm 0.3$

$8.3 \pm 0.5$

$88.7 \pm 1.5$

$0.8 \pm 0$.

$26.6 \pm 1.6$

$26.8 \pm 1.4 \quad 0.6 \pm 0.1$

$0.5 \pm 0.0$

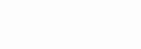

$1.5 \pm 0.0$
$29.2 \pm 2.0$
$29.0 \pm 0.8$

$29.0 \pm 0.8$
$8.1 \pm 0.6$

$\begin{array}{rrr}0.5 \pm 0.0 & 0.7 \pm 0.0 & 0.6 \pm 0.2 \\ 6.0 \pm 0.1 & 11.8 \pm 0.5 & 4.4 \pm 0.3 \\ 6.5 \pm 0.0 & 10.5 \pm 1.1 & 2.3 \pm 0.3 \\ 1.2 \pm 0.4 & 2.5 \pm 0.3 & 0.2 \pm 0.0\end{array}$

10. San Onofre (CA)

$(2 / 79)(2,9-3,2)$
control Top A

Control Top A

$1.8 \pm 1.5 \quad 7.7 \pm 0.3$

$24.7 \pm 20.4 \quad 85.5 \pm 4.5$

Chlorinated Bottom A $100.8 \pm 5.3 \quad 25.8 \pm 1.6$ nd

nd nd

nd
$6.1 \pm 0.1 \quad 1.3 \pm 0.0 \quad 1.7 \pm 0.20 .6 \pm 0.7$

$\begin{array}{llll}9.6 \pm 0.3 & 1.9 \pm 0.0 & 3.8 \pm 0.3 & 0.8 \pm 0.1\end{array}$

(a) Sample evaporated almost to dryness in interval between ether analysis and GPC separation. 
TABLE 14. Halogen Recovery in Organic Fractions Expressed as $\mu \mathrm{g} / \mathrm{l}$ Chlorine

\begin{tabular}{|c|c|c|c|c|c|c|}
\hline \multirow{2}{*}{\multicolumn{2}{|c|}{$\begin{array}{l}\text { STATION } \\
\text { (DATE) (CI ADOEO } \mathrm{mg} / \mathrm{L} \text { ) }\end{array}$}} & \multirow{2}{*}{$\begin{array}{l}\text { CHLORINE TO } \\
\text { HALOFORMS } \\
\text { (PURGE \& TRAP) }\end{array}$} & \multirow{2}{*}{$\begin{array}{c}\text { CHLORINE TO } \\
\text { NONHALOFORMS } \\
(<800 \mathrm{MW})\end{array}$} & \multicolumn{3}{|c|}{ CHLORINE TO SILICA GEL FRACTIONS } \\
\hline & & & & HEX/ETHER & ETHER & $\mathrm{MeOH}$ \\
\hline $\begin{array}{l}\text { 1. COLUMBIA R. (WA) } \\
(5 / 79)(2.7-3.0)\end{array}$ & $\begin{array}{l}\ddagger \mathrm{Cl} \\
\ddagger \mathrm{N}\end{array}$ & 11.9 & .37 & .19 & .07 & .06 \\
\hline $\begin{array}{l}\text { 2. SEQUIM BAY (WA) } \\
(8 / 78)(1.8)\end{array}$ & $\begin{array}{l}\mathrm{Cl} \\
\mathrm{N}\end{array}$ & $\begin{array}{l}8.7^{*} \\
\text { nd }\end{array}$ & 1.48 & 37 & 23 & .04 \\
\hline $\begin{array}{l}\text { 3. OHIOR. (WV) } \\
(8 / 78)(4,0-5.3)\end{array}$ & $\begin{array}{l}\mathrm{Cl} \\
\mathrm{N}\end{array}$ & 8.4 & .49 .62 & .07 .13 & .07 .07 & .02 .09 \\
\hline $\begin{array}{l}\text { 4. L. MICHIGAN }(M)) \\
(8 / 78)(3.0-3.8)\end{array}$ & $\begin{array}{l}\mathrm{Cl} \\
\mathrm{N}\end{array}$ & 3.5 & 39.40 & .10 .11 & $.06 . .04$ & .01 .01 \\
\hline $\begin{array}{l}\text { 5. MISSOURI R. (MO) } \\
(9 / 78)(3.6-4.8)\end{array}$ & $\begin{array}{l}\mathrm{Cl} \\
\mathrm{N}\end{array}$ & 19.9 & $.84,99$ & .20 .22 & .32 .18 & .07 .07 \\
\hline $\begin{array}{l}\text { 6. TENNESSEE R. }\{\mathrm{KY}\} \\
(9 / 78)(4.3-4.7) \\
\end{array}$ & $\begin{array}{l}\mathrm{Cl} \\
\mathrm{N}\end{array}$ & 25.4 & $1.26,1.28$ & .35 .21 & .40 .39 & $.21 . .14$ \\
\hline $\begin{array}{l}\text { 7. CAPE FEAR (NC) } \\
(10 / 78)(4.8-5.7)\end{array}$ & $\begin{array}{l}\mathrm{Cl} \\
\mathrm{N}\end{array}$ & $32.9^{*}$ & 3.14 & 94 & .32 & nd \\
\hline $\begin{array}{l}\text { 8. L. NORMAN }\langle\text { NC) } \\
(10 / 78)(4.1)\end{array}$ & $\begin{array}{l}\mathrm{Cl} \\
\mathrm{N}\end{array}$ & 4.2 & $1.04,1.03$ & .21 .23 & $.42,37$ & .16 .08 \\
\hline $\begin{array}{l}\text { 9. CONNECTICUT.R. (CT) } \\
(10 / 78)(4.3-5.0)\end{array}$ & $\begin{array}{l}\mathrm{Cl} \\
\mathrm{N}\end{array}$ & 21.1 & .57 & .15 & .30 & .07 \\
\hline $\begin{array}{l}\text { 10. SAN ONOFRE (CA) } \\
(2 / 79)(2.9-3.2)\end{array}$ & $\begin{array}{ll}\mathrm{Cl} \\
\mathrm{N}\end{array}$ & 6.3 & 1.43 & .58 & .43 & .13 \\
\hline
\end{tabular}

$\mp C l=$ Chlorinated

$N=$ Nonchlorinated

Bromoform analysis performed using XAD-2 adsorption method 
TABLE 15. Halogen Recovery from XAD-2 Columns in Series Expressed as $\mu \mathrm{g} / \mathrm{l}$ Chlorine

\begin{tabular}{|c|c|c|c|c|c|}
\hline \multirow{2}{*}{\multicolumn{2}{|c|}{$\begin{array}{l}\text { STATION } \\
\text { (DATE) (CI ADDED } \mathrm{mg} / \mathrm{L} \text { ) }\end{array}$}} & \multirow{2}{*}{$\begin{array}{l}\text { CHLORINE TO } \\
\text { NONHALOFORMS } \\
\text { (<800 MW) }\end{array}$} & \multicolumn{3}{|c|}{ CHLORINE TO SILICA GEL FRACTIONS } \\
\hline & & & HEX/ETHER & ETHER & $\mathrm{MeOH}$ \\
\hline $\begin{array}{l}\text { 1. COLUMBIA R. (WA) } \\
(5 / 79)(2.7-3.0)\end{array}$ & $\begin{array}{l}\ddagger T \\
\ddagger B\end{array}$ & .37 & 19 & .07 & .06 \\
\hline $\begin{array}{l}\text { 2. SEQUIM BAY (WA) } \\
(8 / 78)(1.8)\end{array}$ & $\begin{array}{l}\mathrm{T} \\
\mathrm{B}\end{array}$ & 1.48 & .37 & .22 & .03 \\
\hline $\begin{array}{l}\text { 3. OHIO R. (WV) } \\
(B / 78)(4.0-5.3)\end{array}$ & $\begin{array}{l}\mathrm{T} \\
\mathrm{B}\end{array}$ & 62 & .14 & .07 & .09 \\
\hline $\begin{array}{l}\text { 4. L. MICHIGAN (MI) } \\
(8 / 78)\{3.0-3.8\}\end{array}$ & $\begin{array}{l}\mathrm{T} \\
\mathbf{B}\end{array}$ & .40 & .11 & .04 & .01 \\
\hline $\begin{array}{l}\text { 5. MISSOURI R. (MO) } \\
(9 / 78)(3.6-4.8)\end{array}$ & $\begin{array}{l}\mathrm{T} \\
\mathrm{B}\end{array}$ & .99 & .04 & .17 & .07 \\
\hline $\begin{array}{l}\text { 6. TENNESSEE R. (KY) } \\
(9 / 78)(4.3-4.7)\end{array}$ & $\begin{array}{l}T \\
B\end{array}$ & 1.28 & .04 & .12 & .14 \\
\hline $\begin{array}{l}\text { 7. CAPE FEAR (NC) } \\
(10 / 78)(4 . B-5.7)\end{array}$ & $\begin{array}{l}\mathrm{T} \\
\mathrm{B}\end{array}$ & 3.14 & .94 & .32 & nd \\
\hline $\begin{array}{l}\text { 8. L. NORMAN (NC) } \\
(10 / 78)(4.1)\end{array}$ & $\begin{array}{l}\mathrm{T} \\
\mathrm{B}\end{array}$ & 1.03 & .23 & .37 & .08 \\
\hline $\begin{array}{l}\text { 9. CONNECTICUT R. (CT) } \\
(10 / 78)\{4.3-5.0\}\end{array}$ & $\begin{array}{l}T \\
B\end{array}$ & .56 & .15 & .30 & .07 \\
\hline $\begin{array}{l}\text { 10. SAN ONOFRE (CA) } \\
(2 / 79)(2.9-3.2)\end{array}$ & $\begin{array}{l}\mathrm{T} \\
\mathrm{B}\end{array}$ & 1.43 & .58 & .08 & .13 \\
\hline
\end{tabular}

$\begin{aligned} t & =\text { top XAD-2 Column } \\ B & =\text { bottorn XAD-2 Column } \\ n d & =\text { not detected }\end{aligned}$ 
top XAD-2 columns. For example, three milligrams per liter chlorine was added to the Columbia River sample, resulting in 11.9 micrograms of chlorine used for the production of haloform and 0.37 micrograms used in the production of the (mostly) haloform free $<800$ mole weight fraction. In this case, we have accounted for less than one percent of the added halogen as organohalogen $(20.4 \%)$, most of which is in the form of haloform. Inspection of the data for the other stations yields a similar result. At all stations, the amount of halogen found by our procedures to be converted to haloforms was less than one percent of the added chlorine, and the non-haloform halogen was considerably less than the haloform halogen. Helz and Hsu (1978) have reported yields of chlorine as haloform to range between $D .43$ and $4.88 \%$ of chlorine added, during their studies of haloform formation from the chlorination of estuarine waters. In the Helz study, chlorine concentrations were 1 and $10 \mathrm{mg} / \mathrm{liter}$. This result is similar to the results obtained in our studies, although in our results, the yields of all chloroorganic halogen were always less than one percent of the chlorine added (a low of $0.13 \%$ for Lake Michigan to a high of $0.78 \%$ for Cape Fear, after correction for procedural 1osses). The lower range found in our studies is at least in part due to the difference in experimental procedures; in the studies of Helz and Hsu (1978), chlorination of waters was carried out in a closed system, whereas our chlorination and sampling procedures involved one-hour residence time in an open, flowing system.

Also presented in Table 14 are the distributions of organochlorine recovered from the silica gel fractions. The first two fractions (hexane/ether and ether) represent those components which are lipophilic and potentially bioaccumulatable. The concentrations of chlorine represented in these fractions are extremely low, on the order of $0.1 \%$ of the chlorine added to the water. However these data must be considered in the context of the procedural losses experienced during the analysis, and the efficiency of the sampling system in recovering them.

The procedural recovery data on Tables 3-6 have given assurance that overall procedural losses for the lipophilic fractions are no greater than $50 \%$. The data on Table 15, in which the chlorine in fractions from the top XAO-2 columns (upper left hand corners) are compared with that in the corresponding bottom XAD-2 columns (lower right hand corners) is very important in forming a judgment as to whether the sampling process was efficient. For most stations, less than half the amount of chlorine was found in the hexane/ether fractions of the bottom columns than was found in the sample fractions from the top columns. The single exception was at Cape Fear, in which essentially the same quantity of chlorine was found in the hexane/ether fraction from the top column $(0.94 \mu \mathrm{g} / \mathrm{l})$ as from the bottom column $(0.95 \mu \mathrm{g} / \mathrm{l})$. Clearly in this case, concentrations of these components were sufficiently high to overload the sampling system. Thus, quantities of chlorine appearing as non-haloform lipophilic organohalogen compounds in the Cape Fear water are in excess of two $\mu \mathrm{g} / \mathrm{l}$, but it is not possible to estimate the actual concentration, since recovery efficiencies cannot be estimated.

On the other hand, for the other nine stations, there is evidence that the bulk of the lipophilic organohalogen material in the hexane/ether fraction 
formed by the chlorination process was trapped on the two XAD-2 columns in series, since much less chlorine was found in these fractions on the bottom column than the top. Thus we can say with reasonable assurance that for all but the Cape Fear station, quantities of halogen appearing as highly 1ipophilic organohalogen components are on the order of a few micrograms per liter of equivalent chlorine. Considering the wide range of compound possibilities it appears quite likely that concentrations of individual lipophilic organohalogen components found by water chlorination under the conditions of power plant cooling water treatment used are in the $\mu \mathrm{g} / \mathrm{\ell}$ (parts-per-trilition) range. In the unlikely event that all the halogen was contained in a very few compounds, their concentrations might conceivably be has high as one $\mu \mathrm{g} / \ell$ (one part-perbillion).

A similar argument may be applied to those components represented in the ethereluted fractions on Tables 14 and 15. Table 15 shows the chlorine content about the same for top and bottom diethylether fractions at the Missouri River and Ohio River stations. The other locations show a decrease in chlorine content in diethylether fraction from top column to bottom. Thus in most cases it appears as if the quantity of chlorinated material of intermediate polarity is also very low, on the order of less than one $\mu \mathrm{g} / \mathrm{l}$.

The results of our studies of XAO-2 extracts, and of the data presented in Tables 12-15 are that haloforms were the principle stable chlorinated organic products isolated from the natural waters studied, when the XAO-2 res in technique was used for sampling. It is conceivable that components of high molecular weight or of a high degree of hydrophilicity were not trapped by the $X A O-2$ resins. In addition, it is possible that toxic components may have been destroyed by the technique of sulfite addition prior to sampling. However, since a primary purpose of this analytical study was to isolate halogenated organic material which may be persistent in the environment and which may be absorbed into biological tissues, the sampling and analytical techniques employed were tailored to fit this purpose. We believe the data have shown that in general the procedures used were adequate to account for the volatile and lipophilic products of water chlorination.

The results of the XAD-2 sampling and fractionation studies have shown that lipophilic, nonhaloform organohalogen products are formed by the low level chlorination of natural waters, and that the total quantity of chlorine incorporated in this material is in the range of a few micrograms per liter of water chlorinated, when the chlorine dose is between $2-4 \mathrm{mg} / 1 \mathrm{iter}$.

\subsection{Examination of XAD-2 Lipophilic Fractions for Individual Components Using GC/MS}

The recovery of lipophilic halogenated organic material from chlorinated water in quantities corresponding to only a few micrograms (parts-per-billion) of chlorine, suggests that the individual components in this fraction are present at nanogram per liter (parts-per-trillion) levels. If all of the halogen found in these fractions is contained in only a few compounds, however, it is conceivable that the concentrations could be much higher. Thus, it has been 


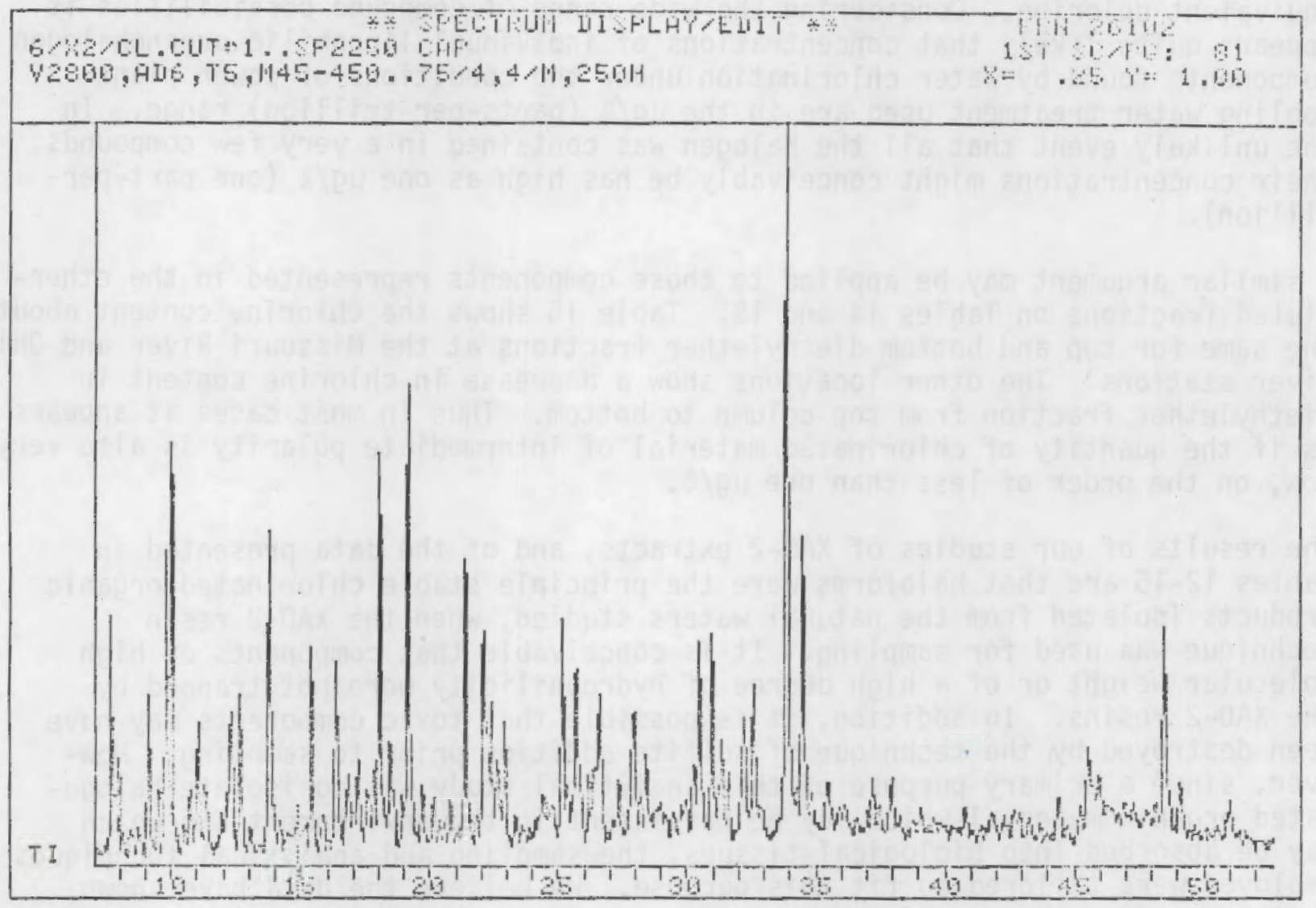

FIGURE 11. Total Ionization Chromatogram Obtained from Lipophilic Fraction of XAD-2 Extract of Chlorinated Tennessee River Water (two microliters injected from a total sample volume of about thirty microliters) 


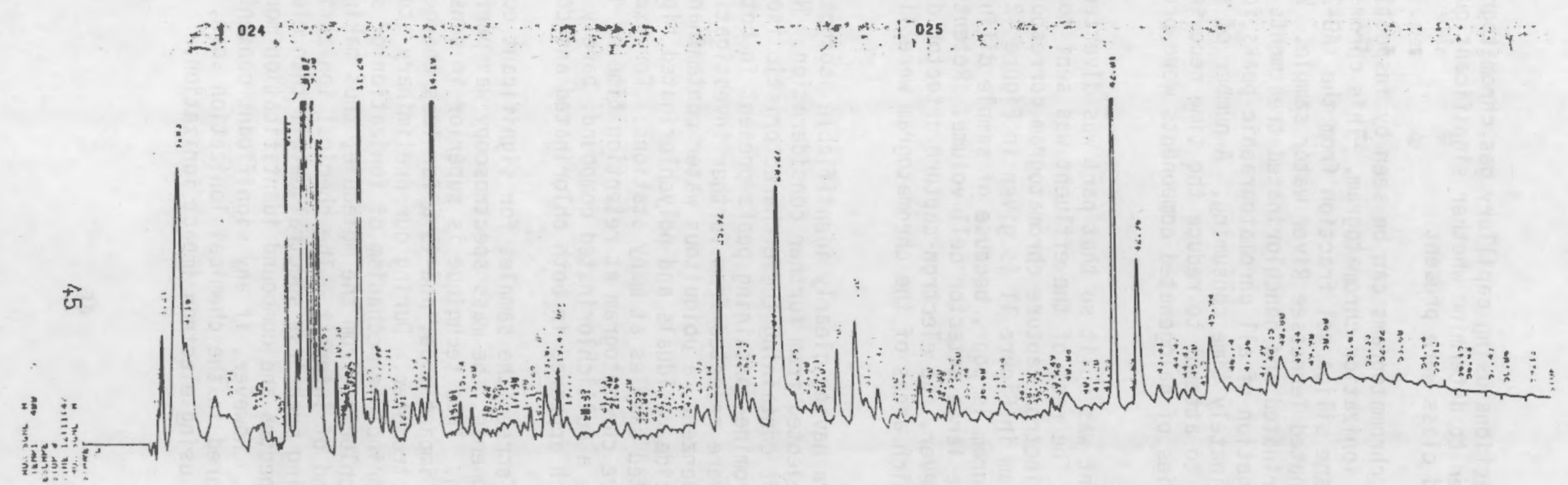

FIGURE 12. Electron Capture Chromatogram Corresponding to the Total Ionization Scan

in Figure 11. Obtained by diverting part of the capillary column efficient through the EC detector 
necessary to examine the fractions using capillary gas chromatography-mass spectrometry (GC/MS) in order to determine whether significant quantities of any one compound or compound class were present.

The complexity of the GC/MS chromatograms can be seen by inspection of Fig. 11 which shows a typical total ionization chromatogram. This chromatogram was obtained from the ether/hexane silica gel fraction from the XAD-2 ether extract corresponding to the chlorinated Tennessee River water sample. With ten sampling stations and both chlorinated and nonchlorinated treatments it is apparent that the systematic investigation of all chromatographic peaks for all samples investigated would be inordinately time consuming. A number of strategies have been employed in order to attempt to reduce the time necessary to determine if significant quantities of halogenated components were present in the sample.

The capillary column effluent was split so that part was diverted through an electron capture detector. The rest of the effluent was sent to the mass spectrometer source. The electron capture chromatogram corresponding to the total ionization chormatogram in Figure 11 is given in Figure 12 . The resolution of this chromatogram is poor, because of sample diffusion after the splitter, and because of the large detector cell volume. Retention times were not very reproducible. However, the electron capture detector did provide useful information as to which areas of the chromatogram were likely to contain halogenated compounds.

Peaks not containing spectra having clearly identifiable isotope ratios due to chlorine or bromine were rejected from further consideration. No attempt was made to include any peak not containing these characteristic isotope ratios. Furthermore, chlorine or bromine-containing peaks present in both chlorinated sample and control sample were rejected from further investigation. Most samples contained dichiorobenzene, a ubiquitous water contaminant. In addition, there were suspected pesticide residuals and polychlorinated biphenyls in both chlorinated and unchlorinated samples at many stations. For example, the large peak in the electron capture chromatogram at retention time of 42 minutes (Figure 12) was found to be a multichiorinated compound, barely detectable by the mass spectrometer, which appeared in both chlorinated and control samples.

Since the objective was to screen the samples for significant concentrations of single halogenated components, the mass spectroscopy was performed using methane chemical ionization. This technique is superior in sensitivity to the more conventional electron impact mode, and is a far less energetic means of generating ions in the spectrometer. During our preliminary studies (Bean, et a]. 1980) we found that a principle mechanism of ionization of some chlorinated components is the loss of chlorine from the molecule, thus making it impossible to identify it as a compound of interest. The chemical ionization technique has the disadvantage of providing much less spectral detail than electron impact, making interpretation of spectra and compound identification more difficult than electron impact ionization. However, if any significant concentration of a halogenated component appeared in the chemical ionization scan, there was the option to rerun the sample using electron impact ionization. 
The results of our mass spectrometric investigations were that no major components containing halogen were found in any of the XAD-2 hexane-ether extracts. None of the major peaks in the total ionization scans from any of the samples examined were found to contain isotope ratios corresponding to chlorine or bromine. Since the peak patterns in samples from all stations were very similar, it is likely that this material represents residual material from the sampling apparatus. The amount of material appearing as a contaminant is smal1, considering that the final sample volume prior to injection into the GC/MS corresponded to about 100 microliters, reduced from a starting water volume of abgut 200 liters. This represents a sample concentration factor of about $2 \times 10^{6}$. Limits of detection in the GC/MS were well above ten partsper-million. Thus we can say with some confidence that lipophilic halogenated components in concentrations of well under one part-per-billion in the water would have been detected, provided they were absorbed on the XAD-2 resin with any efficiency, and provided their molecular weight and volatility was sufficient to allow them to pass through the chromatographic column.

Very few components which were not found in controls could even be tentatively identified because of their low concentrations, and because of the lack of spectral detail available from the chemical ionization mode of mass spectra generation. The XAD-2 samples found to contain the largest number of compounds associated with water chlorination were those from the Tennessee River. The spectra and GC/MS scans for these compounds are presented in Appendix $C$.

\subsection{Examination of XAD-2 Carbonate Extracts for Phenols}

Phenols could be identified with a fairly high degree of confidence because of the derivatization technique employed. Formation of the acetates provided both the means of eliminating interfering material and the means of unambiguous identification of the compounds as phenols. Phenol acetates give a very characteristic fragmentation pattern in which there is a loss of ketene $\left(\mathrm{CH}_{2}=\mathrm{C}=0\right)$ from the molecule, producing a strong signal at a mass of 42 amu less than the molecular ion. Hence the principal electron impact ions for, say, chlorophenol acetate (molecular weight $=170.5$ ) are the two isotope peaks at 170 and 172 (M) for the molecular ion plus two peaks corresponding to the elimination of ketene at 128 and $130(M-42)$.

In the chemical ionization mode employed for these studies, the molecular ion for chlorophenol acetate is one greater than the mass because of proton addition. Thus we would have $171,173(\mathrm{M}+1)$ for the molecular ion. The ions indicative of loss of ketene has been observed to occur at both $M-42$ and $M+1-42$ $(M-41)$. This is illustrated in Figure 13 which gives the background subtracted spectra obtained for a phenol from the Connecticut River, tentatively identified as a chlorophenol. Note the principal ions at $171,173(M+1)$ and the two prominent fragmentation ions at 129, 131 (M-41) corresponding to a 10ss of 42 from the principal ion. However one can also observe a signal at $M-42$ (128, 130). Tre relative signal strengths from these two types of fragments arising from ketene loss varied from compound to compound, and also from run to run for the same compound. This indicates that a number of variables were operating together to produce the fragmentation. For the most part, both fragment masses 


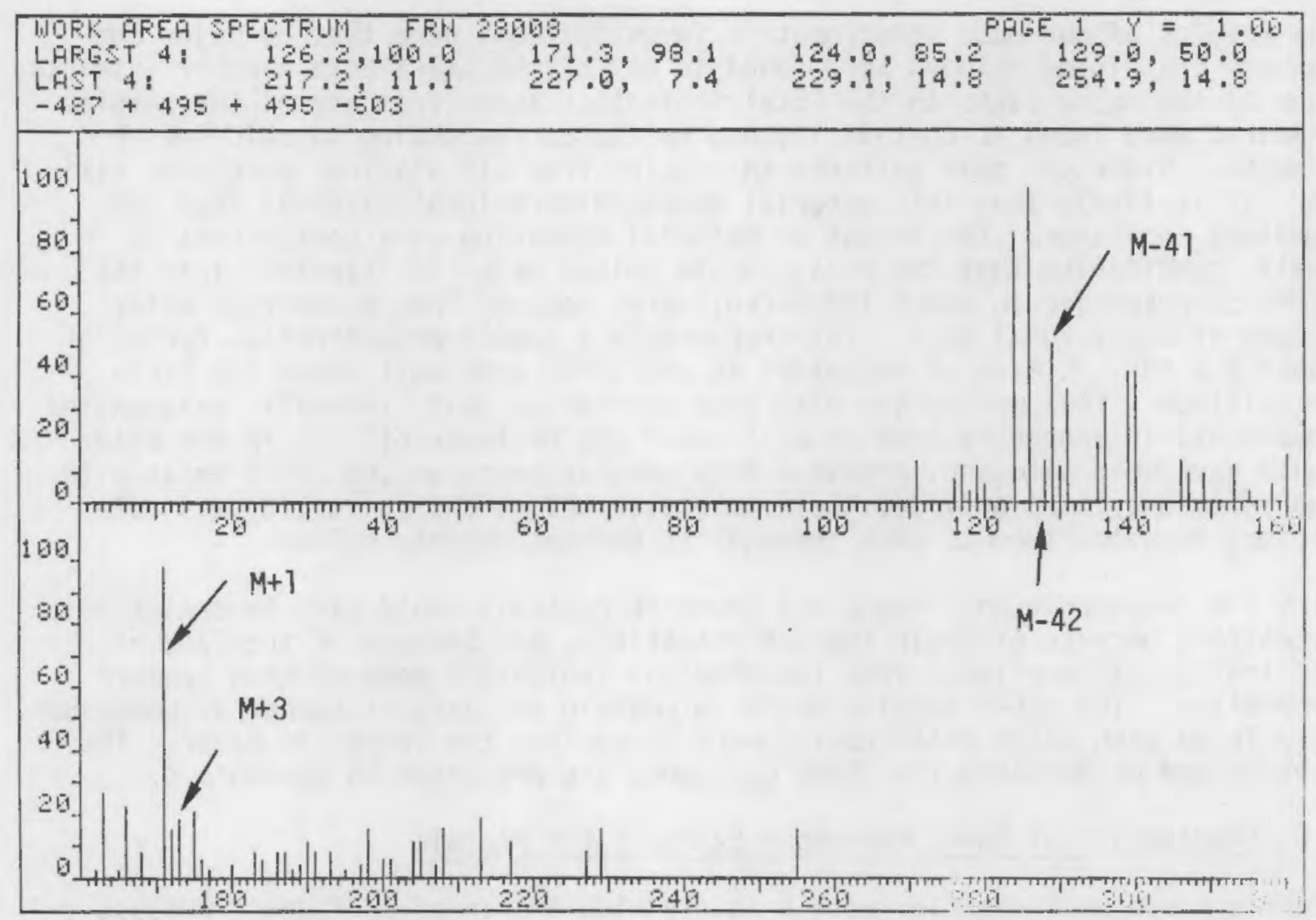

FIGURE 13. Background Subtracted Spectra of Component Found at RT $=19.6$ Using Chromatograms Shown in Figure 14, Showing Principle Fragmentation Ions of Monochlorophenol.

(M-41 and M-42) were present; however the presence of either one was taken by us as sufficient criteria for the identification of phenol in the environmental sample.

Table 16 summarizes the phenols found in the carbonate extracts of the XAD-2 columns. Phenols were identified in samples from seven of the ten locations investigated. Only one station (Cape Fear) contained sufficient quantities of phenols such that they appeared as peaks in the total ionization scan. The phenols identified from samples taken from most stations were found by specifically looking for them using single ion reconstruction techniques. Thus, other phenols could be present in the samples in addition to those reported. Figure 14 shows the single ion reconstructs used to find the chlorophenol from the Connecticut River discussed above. As these chromatograms show, the $M+7$, $M+3$, and $M-41$ peaks $(171,173,129)$ are prominently displayed even though no evidence of this compound is found in the lower trace of the total ionization chromatogram. 
TABLE 16. Phenols Identified in Chlorinated Water Samples. (a) (Retention times for phenols relative to trichiorophenol)(b)

\begin{tabular}{|c|c|c|c|c|c|c|c|}
\hline Phenolic Compound & $\begin{array}{l}\# 1 \\
\text { Columbia } \\
\text { River } \\
\end{array}$ & $\begin{array}{l}\text { \#3 } \\
\text { Ohio } \\
\text { River } \\
\end{array}$ & $\begin{array}{c}\# 5 \\
\text { Missouri } \\
\text { River } \\
\end{array}$ & $\begin{array}{c}\# 6 \\
\text { Tennessee } \\
\text { River } \\
\end{array}$ & $\begin{array}{c}\# 7 \\
\text { Cape } \\
\text { Fear } \\
\end{array}$ & $\begin{array}{l}\# 8 \\
\text { Lake } \\
\text { Norman } \\
\end{array}$ & $\begin{array}{c}\# 9 \\
\text { Connecticut } \\
\text { River } \\
\end{array}$ \\
\hline Chlorophenol & & & 0.637 & & & 0.680 & $0.693(?)$ \\
\hline Methylchlorophenol & & 0.802 & 0.807 & & & & 0.830 \\
\hline Dimethylchiorophenol & & & & 1.036 & & & 1.021 \\
\hline Dichlorophenol & $\begin{array}{l}0.854 \\
0.885\end{array}$ & $\begin{array}{l}0.815 \\
0.850\end{array}$ & 0.821 & $\begin{array}{l}0.821 \\
0.860\end{array}$ & & $0.844(?)$ & 0.855 \\
\hline Bromophenol & & & $1.086(?)$ & & & & \\
\hline Methyldichlorophenol & $1.055(?)$ & & $\begin{array}{l}0.986 \\
1.081\end{array}$ & 1.081 & & & $\begin{array}{l}0.989 \\
1.064\end{array}(?)$ \\
\hline Dimenthyldichlorophenol & & & & & & & 1.131 \\
\hline Trichlorophenol & $1: 000$ & $1.000(?)$ & 1.000 & 1.000 & 1.000 & 1.000 & 1.000 \\
\hline Bromoch1orophenol & & & 0.946 & 0.955 & & & 0.961 \\
\hline Bromodichlorophenol & & & $\begin{array}{l}1.130 \\
1.139\end{array}$ & $\begin{array}{l}1.135 \\
1.149\end{array}(?)$ & $\begin{array}{l}1.144 \\
1.135\end{array}$ & & \\
\hline Dimethyldibromophenol & & & & & 1.423 & & \\
\hline Dibromochlorophenol & & & $\begin{array}{l}1.265 \\
1.269\end{array}$ & & $\begin{array}{l}1.265 \\
1.274\end{array}$ & & sen \\
\hline Tribromophenol & & & & & 1.395 & & \\
\hline
\end{tabular}

(a) A question mark indicates that spectral quality left doubt as to identity

(b) Two retention times indicates two isomers found 


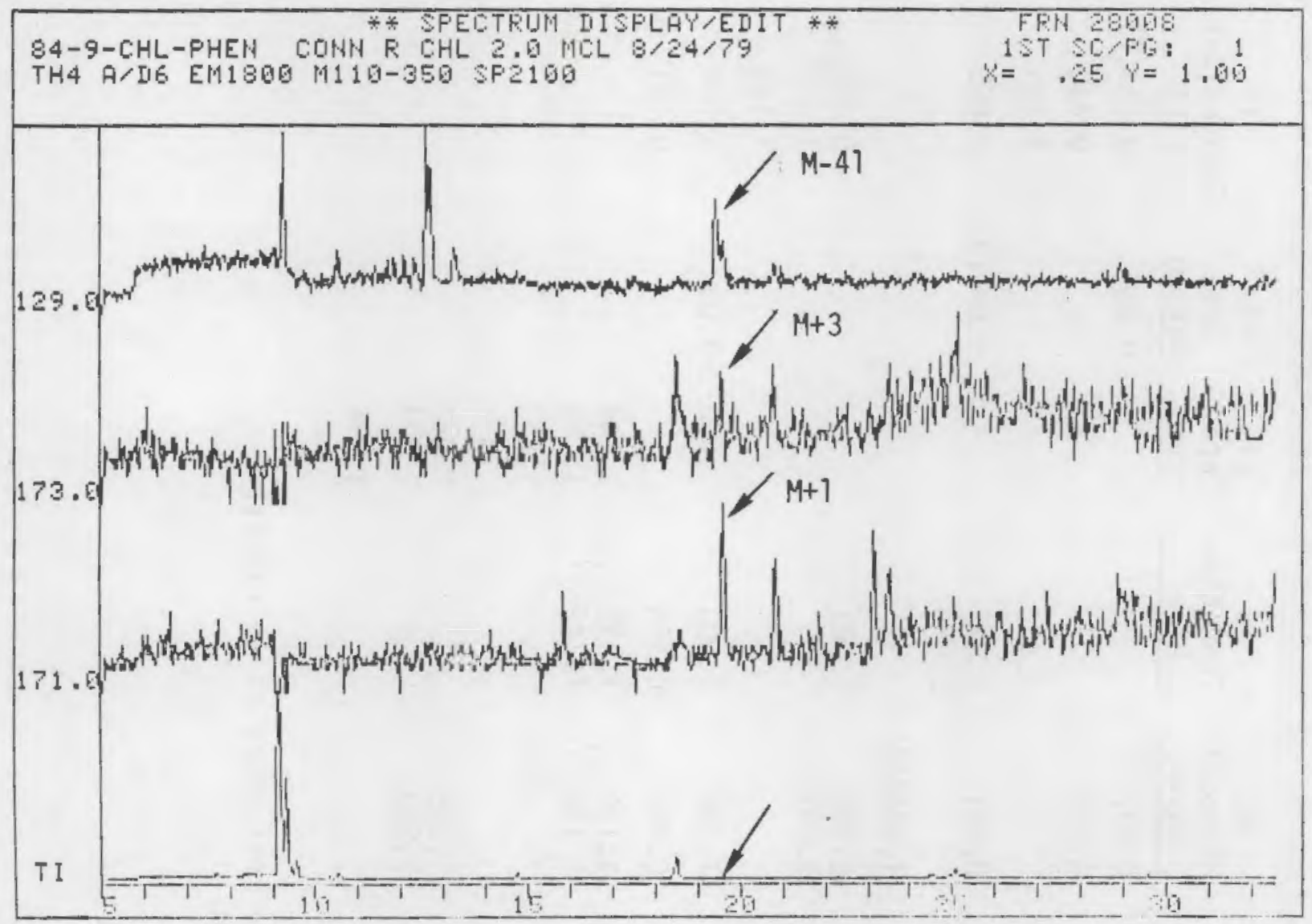

FIGURE 14. Ion Chromatograms from Chlorinated Connecticut River Phenol Sample. Note coincidence of peaks relating to principal ions at Retention Time $=19.6$ min which is used as an aid to determining the phenol in the presence of sample. Note absence of peak in total ionization chromatogram at arrow.

The following criteria were used in the assignment of identity for a phenol:

1. Presence of $M+1, M+3$ and $M-41 / M-42$ in the single ion scan

2. Halogen isotope ratios reasonably consistent with those predicted from the structural assignment

3. A retention time consistent with the same structural assignment in another sample.

If 1 and 3 were true, but the quality of the spectra were poor the identification was considered questionable and a question mark used to indicate this in Table 16. Absence of two of the criteria eliminated a candidate from further consideration. Table 16 shows the retention times relative to trichlorophenol (found in all seven samples containing phenols). Presence of two retention times indicates presence of two isomers of the same structural type. 
No halogenated phenols could be identified in samples from Sequim Bay (Station \#2), Lake Michigan (Station \#4), San Onofre (Station \#10), or any of the controls. It is difficult to estimate the concentrations of phenols in the original water samples for two reasons. First, the efficiency of the XAD-2 resins for adsorption of phenols is not as well documented as is that for lipophilic material, and the efficiency of absorption is $\mathrm{pH}$ dependent (Junk, et al. 1974). It would have been preferable to sample phenols at a pH of 2 in order to ensure good phenol recovery, but practical considerations dictated a $\mathrm{pH}$ of about 4.5 in order to minimize acid consumption. The second reason for a lack of good quantitative information is that for the most part no peaks appeared in the total ion scan. This suggests that concentrations of phenols in the samples analyzed were at the $\mu \mathrm{g} / \mathrm{l}$ (part-per-million) level. Comparison of the response of trichlorophenol standards in the electron capture detector with the trichlorophenol responses in the samples also indicated that phenol levels were well below $\mu \mathrm{g} / \mathrm{l}$ concentrations. Thus phenol concentrations were well below the $\mu \mathrm{g} / \mathrm{L}$ (part-per-billion) level in the chlorinated water samples.

Total ion chromatograms and spectra obtained for phenols found in chlorinated Missouri River water and Cape Fear water are included in Appendix D. The spectra presented in the examples are typical of the range of results obtained at all stations. 



\section{CONCLUSIONS AND RECOMMENDATIONS}

- These studies have shown that adding chlorine to natural waters in concentrations of a few milligrams per liter results in an increase in the quantity of lipophilic chlorinated organic material (material which can be extracted using XAD-2 resins).

- Haloforms are the predominant stable lipophilic products resulting from the low level chlorination of natural waters. Chloroform is the principal haloform product from fresh water chlorination, bromoform from salt-water chlorination. Concentrations of haloforms found in these studies ranged from 2 to $55 \mu \mathrm{g} / \mathrm{l}$. These concentrations are comparable to, and are in some instances substantially lower than, those found in U.S. domestic drinking waters. Haloforms account for most of the organically bound chTorine found in XAD-2 extracts of the water.

- Concentrations of non-haloform stable lipophilic halogenated compounds produced by low level chlorination appear to be very low, on the order of nanograms per liter.

- Trace amounts of bromide ion in fresh water bodies have a profound influence on the distribution of haloform types produced by chiorination. Bromide concentrations in excess of ten micrograms per liter produced significant quantities of mono- and dibrominated haloforms.

- Halogenated phenols resulting from the chlorination process have been found in seven of the ten locations. They were not found in chlorinated sea water, but were found at the Cape Fear estuary, which contained fifty per cent seawater.

- While our experimental low-level chlorination of natural waters has indicated that very low yields of stable halogenated products are produced, these results should be verified by conducting a similar analytical program at nuclear power plants which use chlorine as a principal means of biofouling control. Studies should be undertaken at several nuclear power stations differing substantially in cooling system design.

- Although the concentrations of organically bound halogen produced from power plant biofouling treatment are apparently quite low, the very large amounts of chlorine used for this purpose present the possibility of gradual environmental accumulation of persistent chlorinated products. To investigate this possibility, sampling of sediment and tissue from sessile organisms should be conducted from inside and outside the discharge plumes of power plants using chlorine, in order to determine if there has been a significant accumulation of organic chlorine due to plant operation. 



\section{REFERENCES}

Bean, R. M., R. G. Riley and P. W. Ryan. 1978. "Investigation of halogenated components formed from chlorination of marine water," pp. 223-234. In: Water Chlorination; Environmental Impact and Health Effects, R. L. Jolley, H. Gorchev and D. H. Hamitton, Jr., (ed.). Ann Arbor Science, Ann Arbor, MI.

Bean, R. M., and R. G. Riley. 1980. Investigation of Halogenated Components Formed from Chlorination of Natural Waters: Preliminary Studies. NUREG/CR-1299. Prepared by Battelle, Pacific Northwest Laboratories for the U.S. Nuclear Regulatory Commission.*

Bellar, T. A., and J. J. Lichtenberg. 1974. Determining volatile organics at microgram-per-liter levels by gas chromatography. J. Am. Water Works Assoc. 66: $739-744$.

Brungs, W. A. 1973. Effects of residual chlorine on aquatic life. J. Water Pollut. Cont. Fed. 45:2180-2193.

Bush, B., R. S. Narang and S. Syrotynski. 1977. Screening for haloorganics in New York state drinking water. Bull. Env. Cont. and Toxicol. 18:436-440.

Carlson, R. M., R. E. Carlson, H. L. Kopperman and R. Caple. 1975. Facile incorporation of chlorine into aromatic systems during aqueous chlorination processes. Env. Scj. and Tech. 9:674-675.

Carpenter, J. H., and C. A. Smith. 1978. "Reactions in chlorinated seawater," pp. 195-208. In: Water Chlorination - Environmental Impact and Health Effects, Vol. 2. R. L. Jolley, H. Gorchev, D. H. Hamilton, Jr., (ed.). Ann Arbor Science, Ann Arbor, MI.

Davis, W. P., B. S. Hester, R. L. Yoakum and R. G. Domey. 1977. Marine ecosystem testing units: Oesign for assessment of benthic organism responses to lowlevel pollutants. Helgolauder Wiss. Meeresunters 30:673-681.

Dowty, B. J., D. R. Carlisle and J. L. Laseter. 1975. New Orleans drinking water sources tested by gas chromatography-mass spectrometry. Env. Science and Technol. 9:762-765.

Dressler, M. 1979. Extraction of trace amounts of organic compounds from water with porous organic polymers. J. Chromatog. 165:167-206.

Drozd, J., and J. Novak. 1979. Headspace analysis by gas chromatography. J. Chromatog. 165:141-165.

Environmental Protection Agency. 1977. Sampling and Analys is Procedures for Screening of Industrial Effluents for Priorjty Pollutants. USEPA Environmental Monitoring and Support Laboratory, Cincinnati, OH. Revised April 1977.* 
Glaze, W. H., and J. E. Henderson, IV. 1976a. Formation of organochlorine compounds from the chlorination of a municipal secondary effluent. $\mathrm{J}$. Water Pollut. Cont. Fed. 47:2511-2515.

Glaze, W. H., J. E. Henderson, IV, and G. Smith. 1975b. "Analysis of new chlorinated organic compounds formed by chlorination of municipal wastewater," pp. 153-175. In: Proc. Conf. on the Environmental Impact of Water Chlorina-

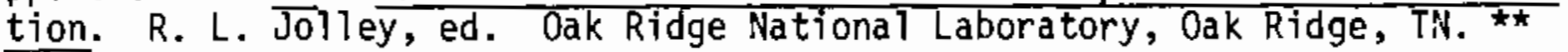

Glaze, W. H., J. E. Henderson, IV, and G. Smith. 1976. "Analys is of new chlorinated organic compounds in municipal wastewaters after terminal chlorination," pp. 155-176. In: Identification and Analys is of Organic Pollutants in Water, L. H. Keith, ed. Ann Arbor, MI.

Glaze, W. H., G. R. Peyton and R. Rawley. 1977. Total organic halogen as water quality parameter: adsorption/microcoulometric method. Env. Sci. and Tech. 11:685-690.

Hamilton, D. H. 1978. Chlorine Application for the Control of Condensor Fouling, in: Water Chiorination, Environmental Impact and Health Effects. V2. R. L. Jolley, Ed., Ann Arbor Science, Ann Arbor, MI. pp. 687-693.

Helz, G. R., and R. Y. Hsu, Volatile chloro- and bromocarbons in coastal waters. Limnol. Oceanog. 23(5):858-869.

Hoen, R. C., C. W. Randa11, R. P. Goode, P. T. B. Shaffer. 1978. Chlorination and Water Treatment of Minimizing Trihalomethanes in Drinking Water. pp. 519535. In: Water Chlorination: Environmental and Health Effects. Vol. 2. R. L. Jolley, H. Gorchev and D. H. Hanilton, Jr., (ed.). Ann Arbor Science, Ann Arbor, MI.

Howland, R. G. and C. J. Wallace. 1978. Chlorine and Activated Carbon Treatment for Removal of Toxic Substances from Water. Ibid. 659-674.

Jolley, R. L. 1977. Identification of Organic Halogen Products. Chesapeake Science 18:122-125.

Jolley, R. L., W. H. Pitt, Jr., F. G. Taylor, Jr., S. J. Hartmann, G. Jones, Jr. and J. E. Thompson. 1978. "An experimental assessment of halogenated organics in waters from cooling towers and once-through systems. pp. 695-706. In: Water Chlorination: Environmental and Health Effects. Vol. 2. R. L. Jolley, H. Gorchev and D. H. Hamilton, Jr., (ed.). Ann Arbor Science, Ann Arbor, MI.

Junk, G. A., J. J. Richard, M. D. Brieser, D. Witiak, J. L. Witiak, M. D. Arguello, R. Vick, H. J. Svec, J. S. Fritz and G. B. Calder. 1974. Use of macroreticular resins in the analysis of water for trace organic contaminants. J. Chromatog. 99:745-762. 
Junk, G. A., J. J. Richard, J. S. Fritz, and H. J. Svec. 1976. "Resin sorption methods for monitoring selected contaminants in water. pp. 134-153. In: Identification and Analysis of Organic Pollutants in Water. L. H. Kieth (ed.). Ann Arbor Science, Ann Arbor, MI.

Krijgsman, W., and C. G. Van de Camp. 1977. Determination of chlorophenols by capillary gas chromatography. J. Chromatog. 131:412-416.

Minear, R. A., and J. C. Bird. 1980. Trihalomethanes: Impact of bromide ion concentrations on the yield, species distribution, rate of formation, and influence of other variables. In: Water Chlorination: Environmental Impact and Health Effects. Ann Arbor Science, Ann Arbor, MI. (in press.)

01 iver, B. G. 1978. Chlorinated non-volatile organics produced by the reaction of chlorine with humic materials. Canadian Research 11(6):21-22.

01 iver, B. G. 1980. Effect of temperature and bromide concentrations on trihalomethane reactions of chlorine with aquatic humic material. In: Hater Chlorination: Environmental Impact and Health Effects. Ann Arbor Science, Ann Arbor, MI. (in press).

Rickabaugh, J., and R. N. Kinman. 1978. Trihalomethane Foundation from Iodine and Chlorine Disinfection of Ohio River Water. pp. 583-591. In: Water Chlorination: Environmental Impact and Health Effects. Vol. 2., R. $[$. Jolley, (ed.), Ann Arbor Science, Inc. Ann Arbor, Mich.

Rook, J. J. 1974. Formation of haloform during chlorination of natural waters. Water Treat, and Exam. 23:234:243.

Rook, J. J. 1977. Chlorination reactions of fulvic acids in natural waters. Env. Sci. \& Tech. 11:478-482.

Shimizu, Y., and R. Y. Hsu. 1975. Interaction of chlorine and selected plant phenols in water. Chem. Pharm. Bul1. 23:2179-2181.

Sonneborn, M. and B. Bohn. 1978. Formation and Occurrence of Haloforms in Drinking Water in the Federa1 Republic of Germany, pp. 537-542. In: Water Chlorination: Environmental and Helath Effects. Vol. 2. R. L. Jolley, H. Gorchev and D. H. Hamitton, Jr., (ed.). Ann Arbor Science, Ann Arbor, MI.

Suffet, I. H., L. Brenner and B. Silver. 1976. Identification of 1,1,1trichioroacetone in two drinking waters: a known precursor in haloform reaction. Env. Sci. and Tech. 10:1273-1275.

Symons, J. M., I. A. Bellar, J. K. Carswell, J. Demarco, K. L. Krepp, C. G. Robeck, D. R. Seeger, C. J. Slocum, B. L. Smith, and A. A. Stevens. 1975. National organics reconnaissance survey for halogenated organics in drinking water. J. Am. Water Works Assoc. 67:634-647.

Wegman, R. C. C., and P. A. Greve. 1977. The microcoulometric determination of extractable organic halogen in surface water; application to surface waters of The Netherlands. The Science of the Total Environment 7:235-245. 
Wegman, R. C. C., and P. A. Greve. 1977. The microcoulometric determination of extractable organic halogen in surface water; application to surface waters of The Netherlands. The Science of the Total Environment $7: 235-245$.

*Available for purchase from the NRC/GPO Sales Program, U.S. Nuclear Regulatory Commission, Washington, D.C. 20555, and the National Technical Information Service, Springfield, VA 22161

**Avajlable for purchase from the National Technical Information Service, Springfield, VA 22151 
APPENDIX A

SAMPLE INVENTORY FROM TEN U.S. LOCATIONS 
TABLE A-1. Sample Inventory

Station \#1

Columbia River

Hanford, Washington

\begin{tabular}{|c|c|c|c|c|c|c|}
\hline Sampling Dates (1979) & $\begin{array}{l}5 / 16- \\
5 / 18\end{array}$ & $\begin{array}{l}5 / 16- \\
5 / 18\end{array}$ & $\begin{array}{l}5 / 16- \\
5 / 18\end{array}$ & $\begin{array}{l}5 / 16- \\
5 / 18\end{array}$ & $\begin{array}{l}5 / 16- \\
5 / 18\end{array}$ & $5 / 18$ \\
\hline $\mathrm{pH}$ & 8.7 & 8.7 & 8.7 & 8.7 & 8.7 & 8.7 \\
\hline Water Temp $\left({ }^{\circ} \mathrm{C}\right)$ & 8.0 & 8.0 & 8.0 & 8.0 & 8.0 & 8.0 \\
\hline Chlorine Added & No & No & Yes & Yes & No & Yes \\
\hline $\begin{array}{l}\text { Calculated Chlorine } \\
\text { Concentration Range (ppm) }\end{array}$ & 0.00 & 0.00 & $2.7-3.0$ & $2.7-3.0$ & 0.00 & 2.7 \\
\hline $\begin{array}{l}\text { Measured TRC after } \\
1 \text { Hour Contact }(\mathrm{ppm})\end{array}$ & $<0.001$ & $<0.001$ & $0.6-2.3$ & $0.6-2.3$ & $<0.001$ & 0.6 \\
\hline \multicolumn{7}{|l|}{ Samples } \\
\hline XAO Column Numbers & $129 / 130$ & $131 / 132$ & $133 / 134$ & $135 / 136$ & 137 & 138 \\
\hline Res in Type & $X A D-2$ & $X A D-2$ & $X A D-2$ & XAD-2 & $X A D-8$ & XAD- 8 \\
\hline Res in Volume (mls) & $82 / 83$ & $82 / 82$ & $82 / 82$ & $82 / 83$ & 18 & 17.5 \\
\hline ter volume & 70 & 263 & 322 & 303 & 23 & 39 \\
\hline
\end{tabular}

Other Samples

Headspace Samples

for $\mathrm{CHCL}_{3}$ ( $\mathrm{Chl}$ and control)

Purge and Trap Sampies quadruplicate
for Volatiles

(Chl and control)

Bulk Water Samples

5 Liters 
TABLE A-1. Sample Inventory (contd)

\begin{tabular}{|c|c|c|c|c|c|c|c|c|c|c|}
\hline \multirow[b]{2}{*}{ Sampling Dates $(197,3\}$} & \multicolumn{4}{|c|}{$\begin{array}{l}\text { Station } \# 2 \\
\text { next to Battelle } \\
\text { Marine Labs. } \\
\text { water uptake } \\
\text { Sequim Bay } \\
\text { Sequim, Washington }\end{array}$} & \multicolumn{3}{|c|}{$\begin{array}{c}\text { Station \#3 } \\
\text { a West Virginia } \\
\text { Water Research } \\
\text { Station } \\
\text { Ohio River } \\
\text { Belville, West Virginia }\end{array}$} & \multicolumn{3}{|c|}{$\begin{array}{c}\text { Station \#4 } \\
\text { on high-energy } \\
\text { surf zone, } \\
\text { sand and } \\
\text { gravel beach } \\
\text { Lake Michigan } \\
\text { Northport, Michigan }\end{array}$} \\
\hline & $\begin{array}{l}8 / 07- \\
8 / 09\end{array}$ & $\begin{array}{l}8 / 07- \\
8 / 09\end{array}$ & $8 / 07$ & $8 / 0$ & $\begin{array}{l}8 / 15- \\
8 / 17\end{array}$ & $\begin{array}{l}8 / 15-8 \\
8 / 17\end{array}$ & $\begin{array}{l}8 / 15- \\
8 / 17\end{array}$ & $\begin{array}{l}8 / 19- \\
8 / 21\end{array}$ & $\begin{array}{l}8 / 19- \\
8 / 21\end{array}$ & $\begin{array}{l}8 / 19- \\
8 / 21\end{array}$ \\
\hline $\mathrm{DH}$ & - & - & - & -8 & 8.2 & 8.2 & 8.2 & 8.8 & 8.8 & 8.8 \\
\hline Water Temp. $\left({ }^{\circ} \mathrm{C}\right)$ & 13.2 & 13.2 & 13.2 & 13.2 & 25.5 & 25.5 & 25.5 & 20.8 & 20.8 & 20.8 \\
\hline Chlorine Added & Yes & No & Yes & No & No & Yes & Yes & No & Yes & Yes \\
\hline $\begin{array}{l}\text { Calculated Chlorine } \\
\text { Concentration Range (ppm) }\end{array}$ & 1.8 & 0.0 & 1.8 & 0.0 & 0.0 & $\begin{array}{l}5.3- \\
4.0\end{array}$ & $\begin{array}{l}5.3- \\
4.0\end{array}$ & 0.0 & $\begin{array}{l}3.8- \\
3.0\end{array}$ & $\begin{array}{l}3.8 \\
3.0\end{array}$ \\
\hline $\begin{array}{l}\text { Measured TRC a After } \\
1 \text { hr Residence Time }\end{array}$ & $n d^{b}$ & nd & nd & nd & nd & nd & nd & nd & nd & nd \\
\hline \multicolumn{11}{|l|}{ XAD Samples } \\
\hline XAD Coiumn Numbers & $28 / 29$ & 30 & 31 & 32 & $33 / 34$ & $35 / 36$ & $37 / 38$ & $39 / 40$ & $42 / 43$ & $44 / 45$ \\
\hline Resin Type & $X A D-2$ & $X A D-2$ & $X A D-2$ & $X A D-2$ & $X A D-2$ & $X A D-2$ & XAD-2 & $\times A D-2$ & $X A D-2$ & $X A D-2$ \\
\hline Resin volume $(\mathrm{mls}$ ) & $88 / 82$ & 82 & 18 & 18 & $82 / 82$ & $81 / 82$ & $83 / 82$ & $82 / 82$ & $82 / 82$ & $82 / 82$ \\
\hline $\begin{array}{l}\text { Avg Flow Rate over XAD } \\
(\mathrm{mls} / \mathrm{min})\end{array}$ & 133 & 125 & 110 & 80 & 112 & 98 & 96 & 98 & 106 & 104 \\
\hline $\begin{array}{l}\text { Water Volume Extracted } \\
\text { (Liters) }\end{array}$ & 304.3 & 198.8 & 20.0 & 20.0 & 252.2 & $220.5^{c}$ & $215.7^{\mathrm{C}}$ & 232.1 & 251.4 & 246.4 \\
\hline \multicolumn{11}{|l|}{ Other Samples } \\
\hline $\begin{array}{l}\text { Headspace Samples for } \\
\text { Chloroform (Chlorinated } \\
\text { and Non-Chlorinated) }\end{array}$ & \multicolumn{4}{|c|}{ Duplicate } & \multicolumn{3}{|c|}{ Dupl icate } & \multicolumn{3}{|c|}{ Duplicate } \\
\hline $\begin{array}{l}\text { Purge and Trap Samples } \\
\text { for Volatiles (Chlorinated } \\
\text { and Non-Chlorinated) }\end{array}$ & \multicolumn{4}{|c|}{ None Taken } & \multicolumn{3}{|c|}{ Duplicate } & \multicolumn{3}{|c|}{ Duplicate } \\
\hline Bulk Water Samples & \multicolumn{4}{|c|}{ None Taken } & \multicolumn{3}{|c|}{ None Taken } & \multicolumn{3}{|c|}{ None Taken } \\
\hline \multicolumn{11}{|c|}{$\begin{array}{l}\text { TRC - (Total Residuat Chlorine) A measure of free Chlorine after uptake by organics. Excess } \\
\text { was scavanged by Na }{ }^{50}{ }_{3} \text { prior to sample exposure to XAD resin. TRC measurements taken with } \\
\text { a ballace and Tiernan Amperometric Titrator. } \\
b_{\text {nd - not determined }}\end{array}$} \\
\hline
\end{tabular}


TABLE A-1. Sample Inventory (contd)

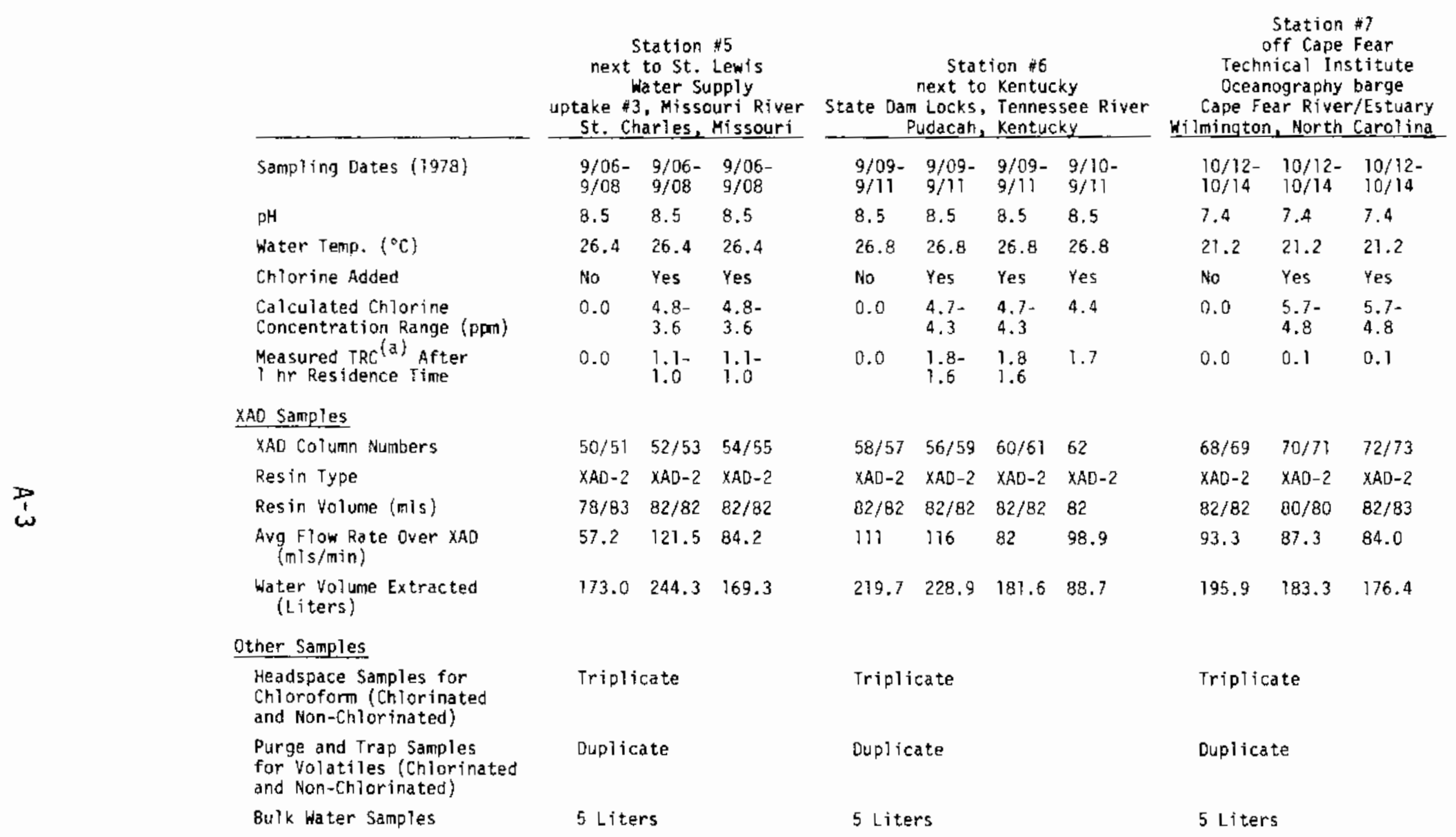

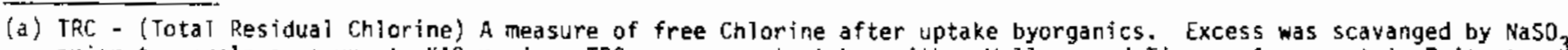
prior to sample exposure to XAO resin. TRC measurements taken with a Wallace and Fiernan Amperometric Tritrator. 


\section{TABLE A-1. Sample Inventory (contd)}

\begin{tabular}{|c|c|c|c|c|c|c|}
\hline \multirow[b]{2}{*}{ Sampling Dates (1978) } & \multicolumn{3}{|c|}{$\begin{array}{c}\text { Station } \# 8 \\
\text { near McGuire Nuclear } \\
\text { Power Plant } \\
\text { water coolant discharge } \\
\text { Lake Nonnan } \\
\text { Charlotte, North Carolina }\end{array}$} & \multicolumn{3}{|c|}{$\begin{array}{c}\text { Station } \# 9 \\
\text { next to Middletown } \\
\text { Sewage Treatment } \\
\text { Plant Effluent } \\
\text { Connecticut River } \\
\text { Middletown, Connecticut }\end{array}$} \\
\hline & $\begin{array}{l}10 / 15 \\
10 / 16\end{array}$ & $\begin{array}{l}10 / 15- \\
10 / 16\end{array}$ & $\begin{array}{l}10 / 15- \\
10 / 16\end{array}$ & $\begin{array}{l}10 / 19- \\
10 / 20\end{array}$ & $\begin{array}{l}10 / 19 \\
10 / 20\end{array}$ & $\begin{array}{l}10 / 19- \\
10 / 20\end{array}$ \\
\hline $\mathrm{pH}$ & 7.0 & 7.0 & 7.0 & 7.2 & 7.2 & 7.2 \\
\hline Water Temp. $\left({ }^{\circ} \mathrm{C}\right)$ & 20.2 & 20.2 & 20.2 & 13.6 & 13.6 & 13.6 \\
\hline Chlorine Added & No & Yes & Yes & No & Yes & Yes \\
\hline $\begin{array}{l}\text { Calculated Chlorine } \\
\text { Concentration Range (ppin) }\end{array}$ & 0.0 & 4.1 & 4.1 & 0.0 & $\begin{array}{l}4.3- \\
5.0\end{array}$ & $\begin{array}{l}4.3- \\
5.0\end{array}$ \\
\hline $\begin{array}{l}\text { Measured } T R C^{\mathrm{a}} \text { After } \\
1 \text { hr Residence Time }\end{array}$ & 0.0 & $\begin{array}{l}2.3- \\
1.8\end{array}$ & $\begin{array}{l}2.3- \\
1.8\end{array}$ & 0.0 & $\begin{array}{l}1.1- \\
0.8\end{array}$ & $\begin{array}{l}1.1- \\
0.8\end{array}$ \\
\hline \multicolumn{7}{|l|}{ XAD Sampies } \\
\hline XAD Col umn Numbers & $74 / 75$ & $76 / 77$ & $78 / 79$ & $80 / 81$ & $82 / 83$ & $83 / 84$ \\
\hline Resin Type & $X A D-2$ & $x A O-2$ & $X A D-2$ & $X A O-2$ & $\times A O-2$ & XAD-8 \\
\hline Resin Volume (m/s) & $82 / 83$ & $85 / 82$ & $82 / 81$ & $83 / 82$ & $82 / 82$ & $82 / 82$ \\
\hline $\begin{array}{l}\text { Avg Flow Rate Over XAO } \\
\text { (mis/min) }\end{array}$ & 103.5 & 112.4 & 114.9 & 90.3 & 97.3 & 170.3 \\
\hline $\begin{array}{l}\text { Water Volume Extracted } \\
\text { (Liters) }\end{array}$ & 189.4 & 205.6 & 210.2 & 162.5 & 175.1 & 304.4 \\
\hline \multicolumn{7}{|l|}{ Other Samples } \\
\hline $\begin{array}{l}\text { Headspace Samples for } \\
\text { Chlorofomi (Chlorinated } \\
\text { and Non-Chlorinated) }\end{array}$ & \multicolumn{3}{|c|}{ Triplicate } & \multicolumn{3}{|c|}{ Triplicate } \\
\hline $\begin{array}{l}\text { Purge and Trap Samples } \\
\text { for Volatiles (Chlorinated } \\
\text { and Non-Chlorinated) }\end{array}$ & \multicolumn{3}{|c|}{ Duplicate } & \multicolumn{3}{|c|}{ Duplicate } \\
\hline BuIk Water Samples & \multicolumn{3}{|c|}{4 Liters } & \multicolumn{3}{|c|}{4 Liters } \\
\hline
\end{tabular}

(a) TRC - (Tota1 Residual Chlorine) A measure of free Chlorine after uptake by organics. Excess was scavanged by $\mathrm{NaSO}_{3}$ prior to sample exposure to XAD resin. TRC measurements taken with dallace and Tiernan Anperometric Titrator. 
TABLE A-1. Sample Inventory (contd)

Station \#10

San Onofre, on

the seaward side

of jetty at Harbor

villa Boatel,

Oceanside, California

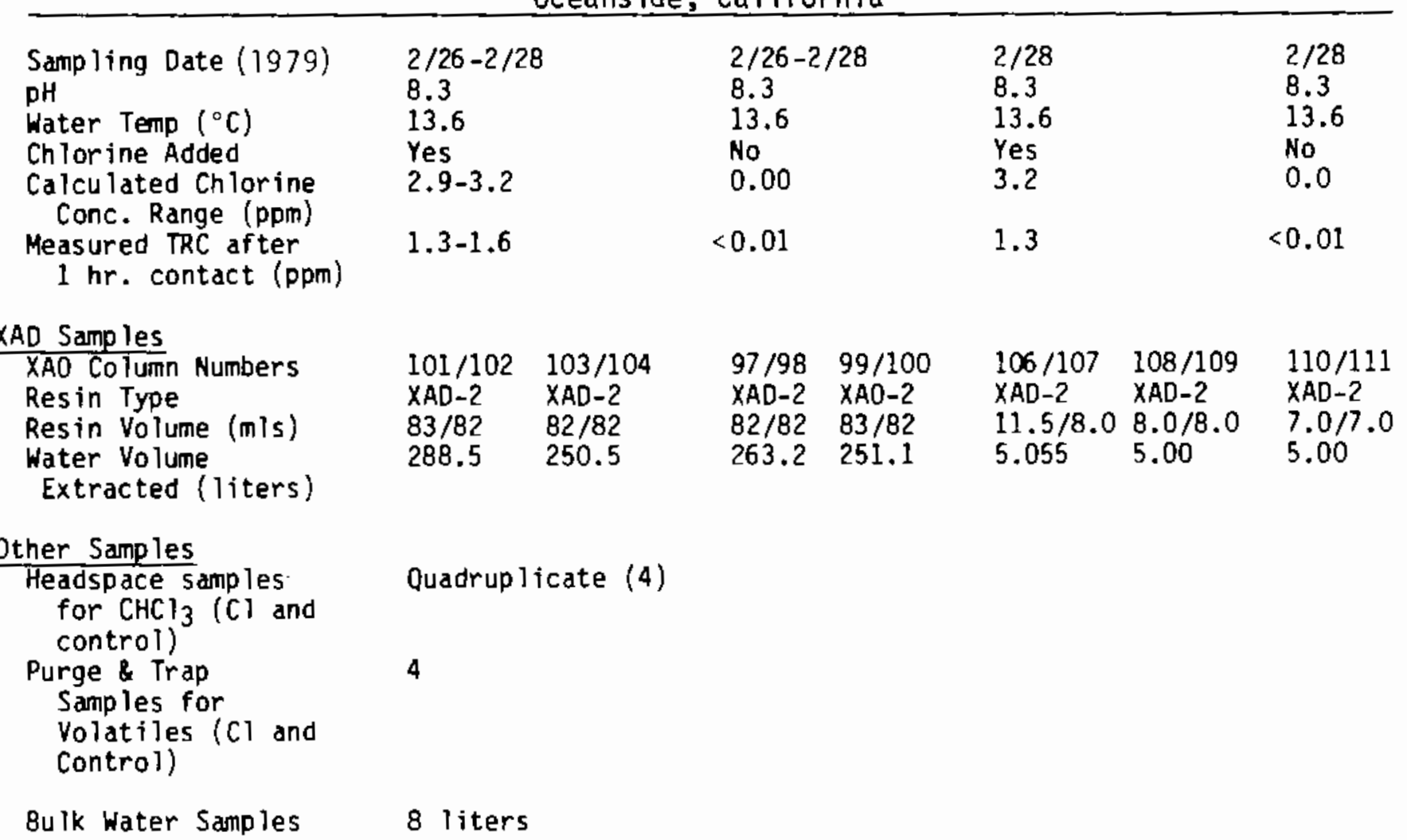



APPENDIX B

PRELIMINARY DATA ON COLUMBIA RIVER

AND SEQUIM BAY XAD-2 EXTRACTS 
APPENDIX B

PRELIMINARY DATA ON COLUMBIA RIVER

AND SEQUIII BAY XAD-2 EXTRACTS

During development of the sampling procedures employed in this study, data was generated on preliminary samples obtained from chlorinated and unchlorinated Columbia River and Sequim Bay waters. The data consists of chlorine recovery data from the separation procedures (Table B-1), total organic halogen vs. haloform halogen (Table B-2) and total halogen analys is of separated fractions (Table B-3). The low recovery of chlorine observed from the silica gel procedure used prompted us to change the procedure. Thus, the data appearing in Table B-3 is not consistent with similar data from these water bodies reported in the main portion of this report. 
TABLE B-1. Recoveries of Organic Chlorine from GPC and Sitica Gel Separations (values are percentages of total organic halogen determined prior to separation: GPC and silica gel experiments each assume $100 \%$ prior to separation experiment)

\begin{tabular}{|c|c|c|c|c|c|c|c|c|c|}
\hline & \multirow[b]{3}{*}{ Description } & \multicolumn{4}{|c|}{ GPC } & \multicolumn{4}{|c|}{ Sllica Gel } \\
\hline \multirow[b]{2}{*}{ Sample } & & \multicolumn{4}{|c|}{ Percent Recoveries } & \multicolumn{4}{|c|}{ Percent Recoveries } \\
\hline & & $>15,000 \mathrm{MW}$ & $15,000-600 \mathrm{MW}$ & $<800 \mathrm{MW}$ & Total & Nonpolar & Polar & Bactrflush & Total \\
\hline & \multicolumn{9}{|c|}{ Fresh Water } \\
\hline $\mathrm{Cl} \# 18$ & $\begin{array}{l}\text { Columbia River Water' } \\
\text { fresh Water Apparatus } \\
0.69 \text { TRC; } 390 \text { \& }\end{array}$ & 0.0 & 0.0 & 96.5 & 96.5 & 29.6 & 7.2 & 15.6 & $\$ 2.4$ \\
\hline $\begin{array}{l}\mathrm{Cl} \text { \# } \mathrm{B} \\
\text { and } 9\end{array}$ & $\begin{array}{l}\text { Columbia River Water } \\
\text { Fresh Water Apparatus } \\
\text { Tandem Columns, } \\
0.99 \text { TRC; } 390 Z \\
\text { CI \#B Top Column }\end{array}$ & 1.2 & 2.5 & 70.9 & 74.6 & 3.1 & 3.8 & 55.0 & 61.9 \\
\hline Sea Water & Cl "9 Bottom Column & 4.4 & 2.8 & 87.2 & 94.4 & 8.2 & 7.1 & 22.0 & 37.3 \\
\hline C) $: 10$ & $\begin{array}{l}\text { Sequim Bay Sea Water } \\
1.7 \text { TRC; } 269 \ell\end{array}$ & 0.1 & 0.5 & 88.7 & 89.3 & 27.4 & 13.2 & 17.4 & 58.0 \\
\hline $\mathrm{Cl} * 11$ & $\begin{array}{l}\text { Sequim Bay Sea Water } \\
\text { No Chlorine; } 311 \text { \& }\end{array}$ & 9.9 & 2.5 & 61.3 & 73.7 & 21.7 & 14.1 & 9.4 & 45.2 \\
\hline $\mathrm{Cl} \approx 12$ & $\begin{array}{l}\text { Sequim Bay Sea Water } \\
2.3 \text { TRC; } 335 \&\end{array}$ & 0.0 & 0.0 & 79.1 & 79.1 & 10.6 & 7.5 & B. 3 & 26.4 \\
\hline $\mathrm{Cl} \cdot 13$ & $\begin{array}{l}\text { Sequim Bay Sea Water } \\
\text { No Chlorine; } 362 \& \text { L }\end{array}$ & 0.0 & 0.0 & 74.8 & 74.8 & 15.6 & 0.0 & 0.0 & 15.6 \\
\hline
\end{tabular}


TABLE B-2. Comparison of Haloform Content in XAD-2 Extracts with Total Organic HaTogen

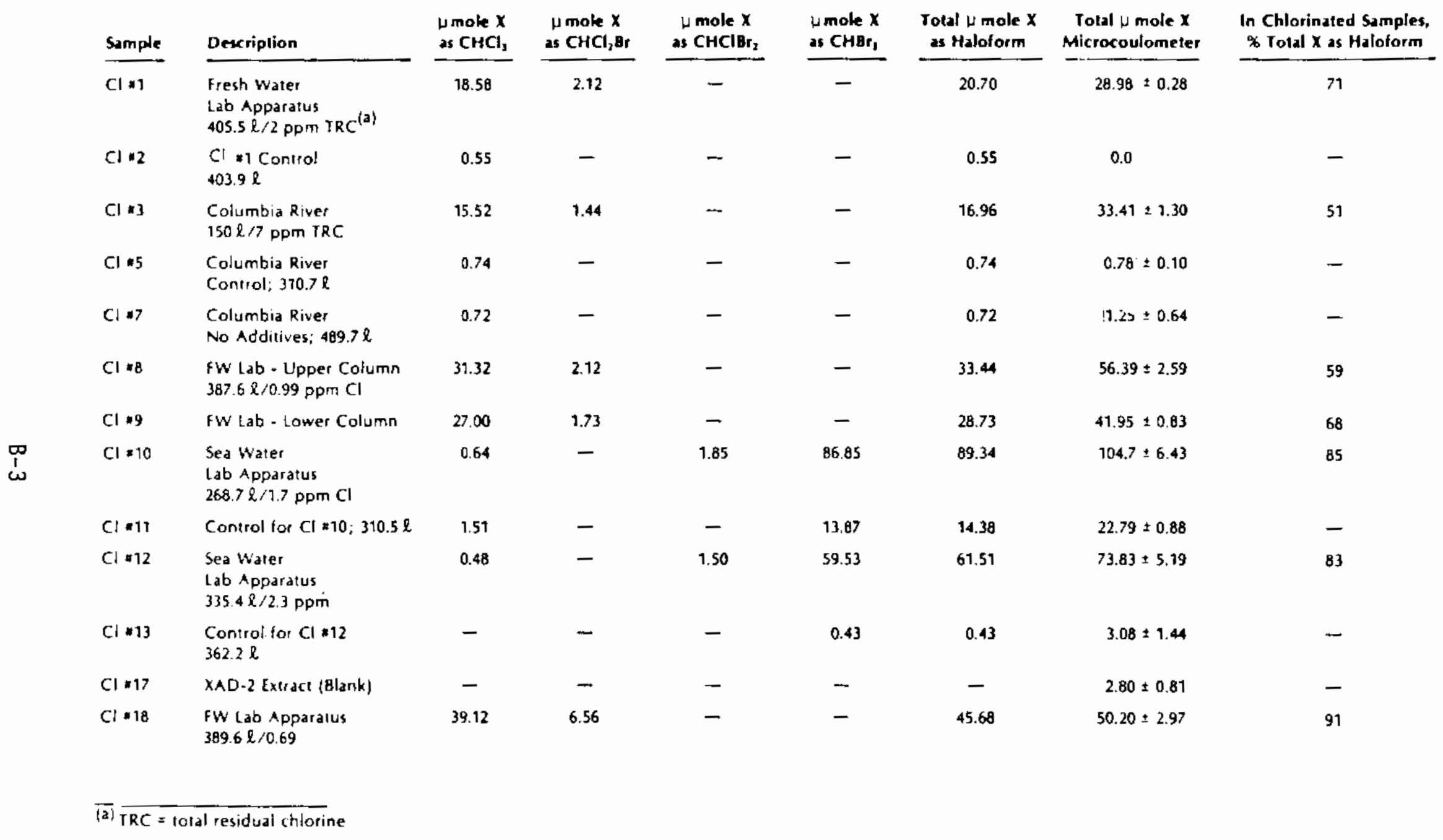


TABLE B-3, Organic Halogen Analys is of Fractions Obtained from Freshwater and Seawater Samples (fractions obtained according to separation scheme on Figure 1 ; halogen values are expressed as nonomoles/l)

\begin{tabular}{|c|c|c|c|c|c|c|c|c|c|c|c|c|}
\hline \multirow[b]{2}{*}{ Somple } & \multirow[b]{2}{*}{ Description } & \multirow[b]{2}{*}{ Date } & \multirow{2}{*}{$\begin{array}{l}\text { Ether } \\
\text { Extract }\end{array}$} & \multicolumn{3}{|c|}{ G.P.C. Fraction } & \multicolumn{3}{|c|}{ silka Gel Fracthons } & \multirow[b]{2}{*}{ Phenols } & \multirow[b]{2}{*}{ Acids } & \multirow{2}{*}{$\begin{array}{c}\text { Methanol } \\
\text { Extract }\end{array}$} \\
\hline & & & & $<800$ & $000-15,000$ & $>15,000$ & Nonpolar & Polar & Backflush & & & \\
\hline \multicolumn{13}{|c|}{ Fresh Water Samples } \\
\hline \multirow[t]{3}{*}{$\begin{array}{l}C l \oplus 8 \\
\text { and } 9\end{array}$} & $\begin{array}{l}\text { Fresh Water Apparatus } \\
0.99 \text { TRC; } 388 \text { \& }\end{array}$ & $5 / 10$ & & & & & & & & & & \\
\hline & $\mathrm{Cl} * 8$ Top Column & & 145.5 & 9.40 & 0.32 & 0.16 & 0.33 & 0.40 & 5.74 & 0.97 & 5.7 & 39.5 \\
\hline & $\mathrm{Cl} \# 9$ Bottom Column & & 108.1 & 7.43 & 0.24 & 0.37 & nd & 0.14 & 1.30 & 0.20 & 3.86 & 29.7 \\
\hline $\mathrm{Cl} \cdot 5$ & $\begin{array}{l}\text { Fresh Water Apparatus } \\
\text { No Chlorine: } 311 \ell\end{array}$ & $4 / 18$ & 2.5 & 0.77 & nd & nd & 0.06 & 0.20 & 0.15 & 0.61 & nd & 3.5 \\
\hline $\mathrm{Cl} * 7$ & $\begin{array}{l}\text { Columbia River Water } \\
\text { No Additions; } 490 \text { \& }\end{array}$ & $4 / 24$ & 2.6 & 0.69 & 0.07 & nd & 0.06 & 0.05 & 0.16 & 0.62 & 0.11 & 51.0 \\
\hline \multicolumn{13}{|c|}{ Sea Water Samples } \\
\hline $\mathrm{Cl} * 10$ & $\begin{array}{l}\text { Sea Water Apparatus } \\
1.7 \text { TRC; } 269 \text { \& }\end{array}$ & $5 / 15$ & 389.4 & 107.01 & 0.67 & 0.10 & 28.61 & 8.99 & 11.85 & nd & 0.06 & 209.7 \\
\hline $\mathrm{Cl} * 1\}$ & $\begin{array}{l}\text { Sea Water Apparatus } \\
\text { No Chlorine; } 311 \text { \& }\end{array}$ & $5 / 15$ & 73.3 & 5.09 & 0.21 & 0.82 & 0.95 & 0.61 & 0.41 & nd & 0.59 & 80.2 \\
\hline $\mathrm{Cl}: 12$ & $\begin{array}{l}\text { Sea Water Apparatus } \\
2.3 \text { TRC; } 335 \ell\end{array}$ & $5 / 17$ & 220.4 & 6.12 & nd & nd & 0.75 & 0.53 & 0.59 & 0.20 & 0.96 & 82.4 \\
\hline $\mathrm{Cl} * 13$ & $\begin{array}{l}\text { Sea Water Apparatus } \\
\text { No Chlorine; } 362 l\end{array}$ & $5 / 17$ & 8.5 & 0.57 & nd & nd & 0.08 & nd & nd & nd & 0.33 & 68.3 \\
\hline \multicolumn{13}{|c|}{ System Blank } \\
\hline $\mathrm{Cl}: 17$ & (Based on 350 \& sample) & $6 / 1$ & 7.99 & 0.21 & nd & nd & nd & nd & nd & nd & 1.42 & nd \\
\hline
\end{tabular}

\footnotetext{
(a) TRC = parts per miliion total residual chlorine
}

(b) nd = not detected 
APPENDIX C

GC/MS SPECTRA FROM ETHER EXTRACTS 


\section{APPENDIX C}

\section{GC/MS SPECTRA FROM ETHER EXTRACTS}

Spectra from the XAD-2 ether extract of chlorinated Tennessee River water are presented as an illustration of the largely negative results obtained from examination of the XAD-2 samples by GC/MS. Figure C-1a shows the large number of peaks present in the capillary chromatogram. Figure $\mathrm{C}-1 \mathrm{~b}$ shows the location in the chromatogram of spectra containing fragments showing isotope ratios characteristic of chlorine. The spectra corresponding to these retention times are presented in Figures $\mathrm{C}-2$ through $\mathrm{C}-8$. Although no identification was possible from the spectra obtained, some of the masses obtained were characteristic of chlorinated hydrocarbons. The Tennessee River sample contained the most, and the highest quantity of material containing chlorine of all samples investigated. 


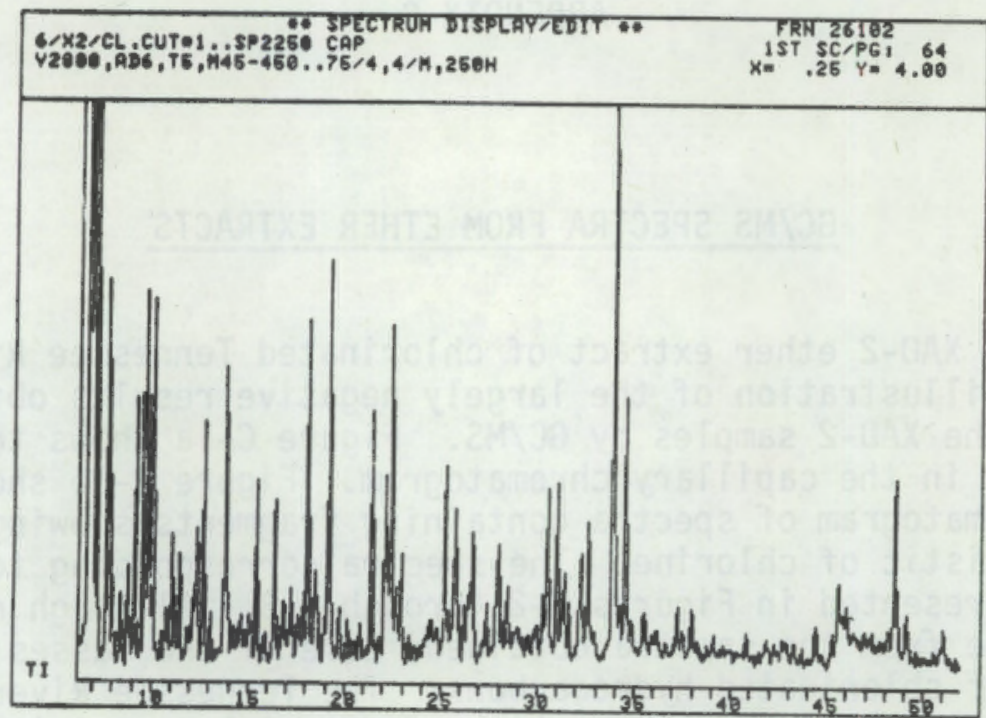

FIGURE C-la. Total Ionization Chromatogram of the Hexane/Ether Fraction of the XAD-2 Ether Extract from Chlorinated Tennessee River Water. Peak heights enhanced fourfold.

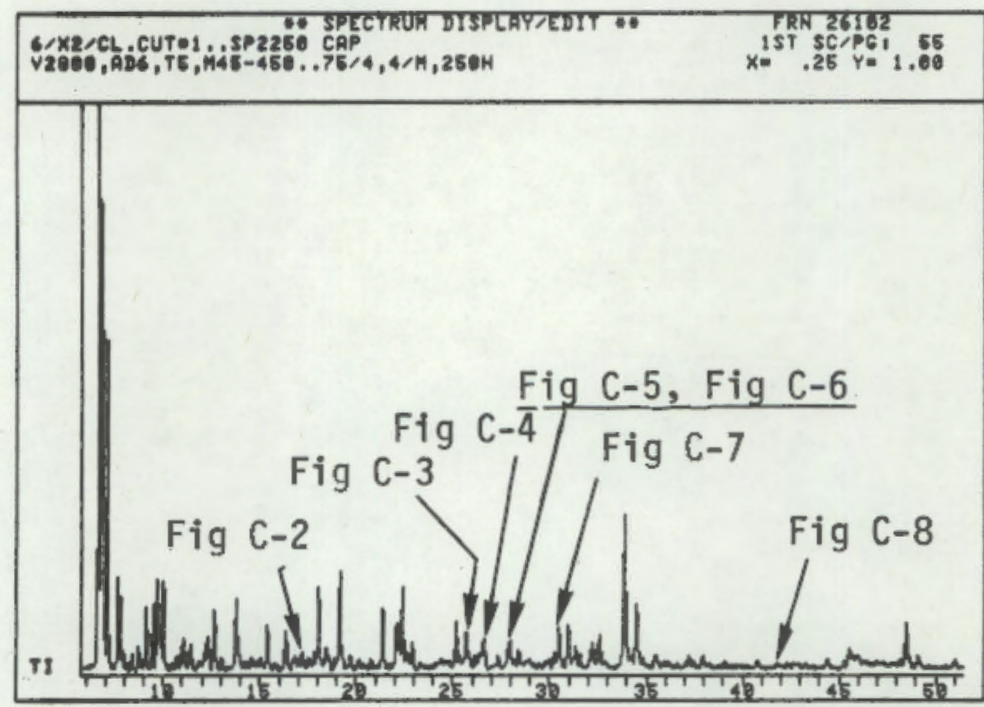

FIGURE C-1b. Same as $\mathrm{C}-1 \mathrm{a}$, Showing Peaks Corresponding to Figs. C-2 Through C-8 


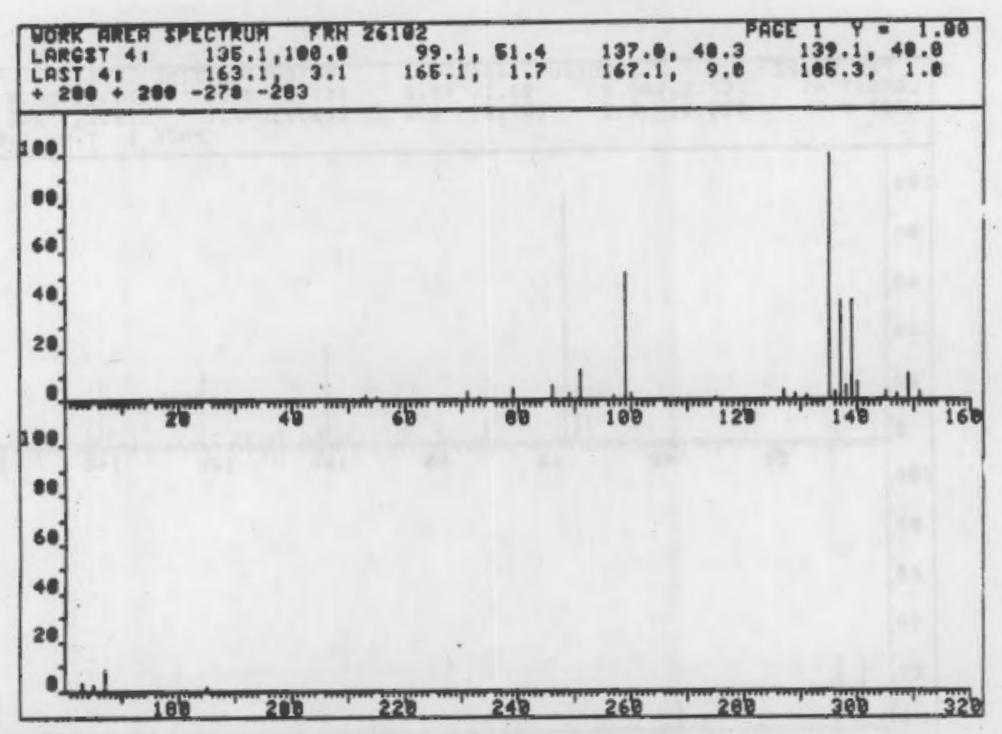

FIGURE C-2. Unknown, possibly Chlorinated, $M=134, R T=16.8$

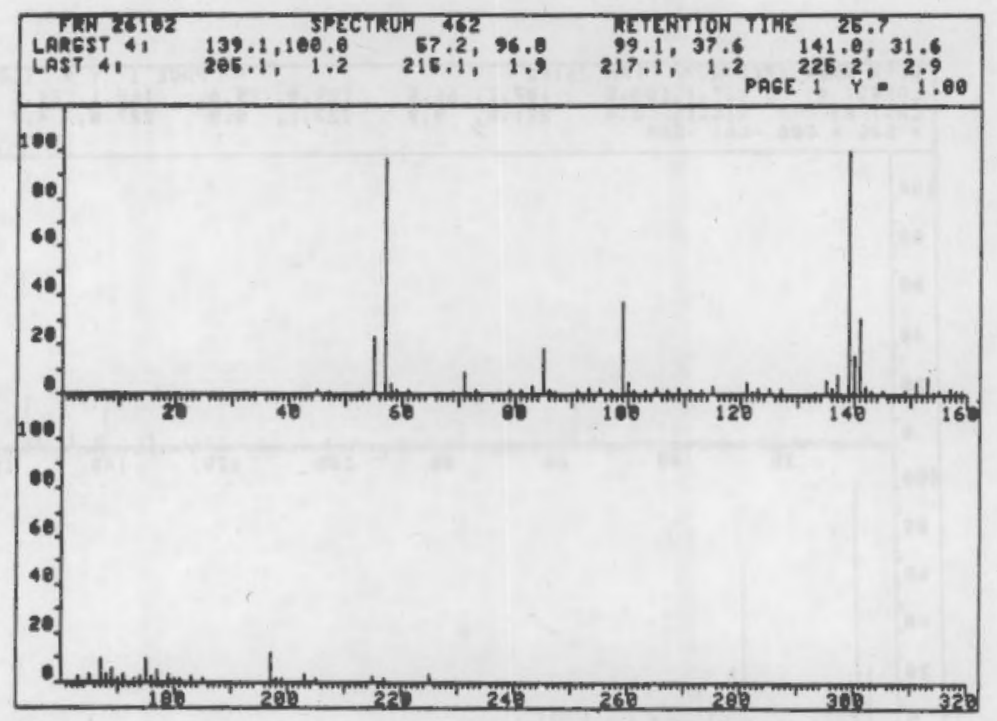

FIGURE C-3. Unknown, $M=138, R T=25.7$ (MW corresponds to Chloros tyrene) 


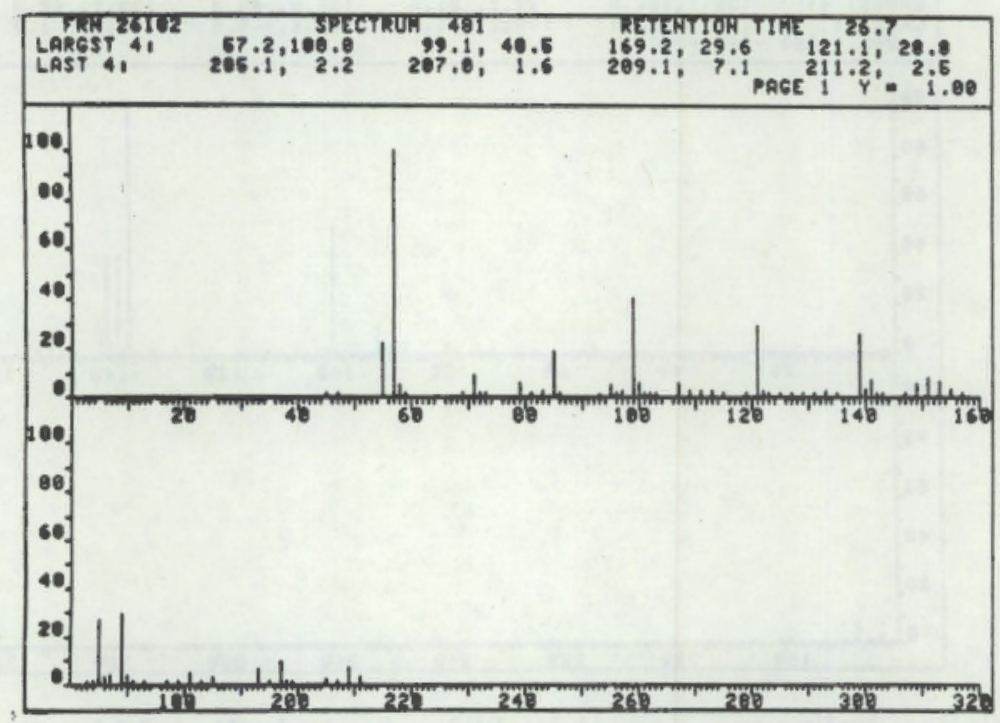

FIGURE C-4. Unknown. $M=138$, RT $=26.7$ (MW corresponds to chlorostyrene)

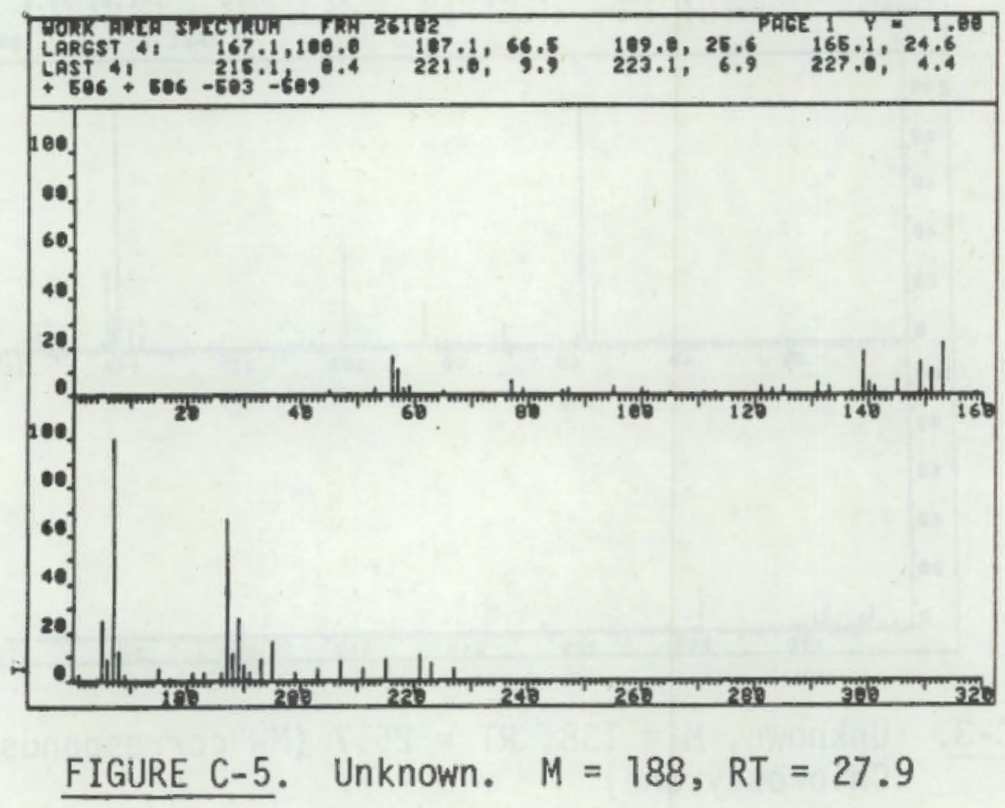




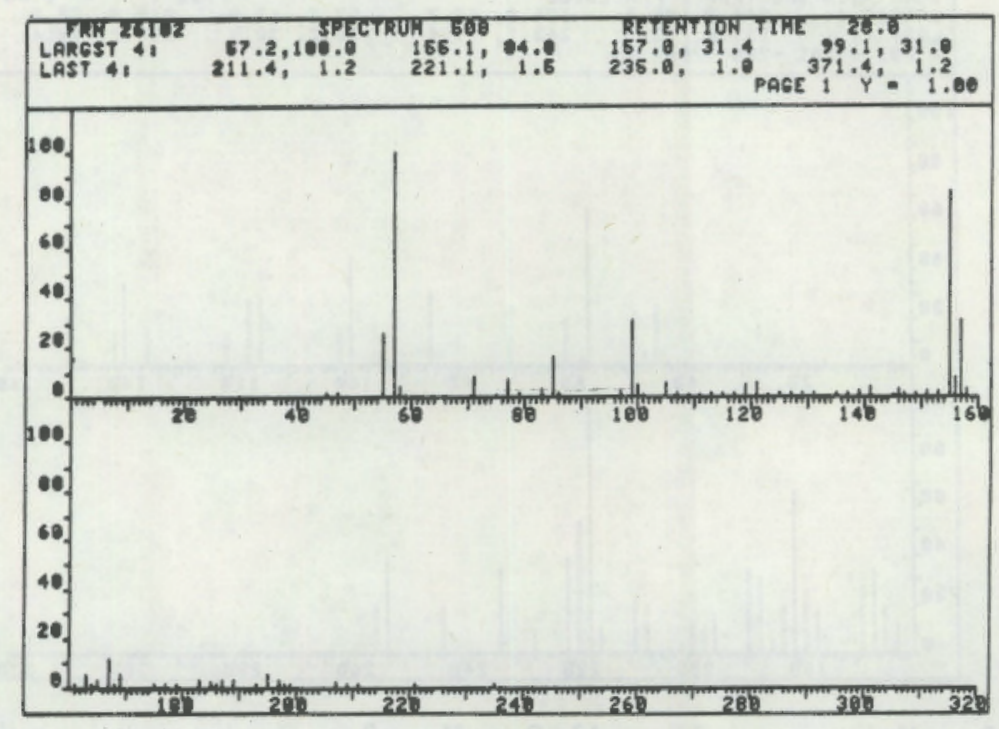

FIGURE C-6. Unknown. $M=154, R T=28.0$ (MW corresponds to trimethylchiorobenzene)

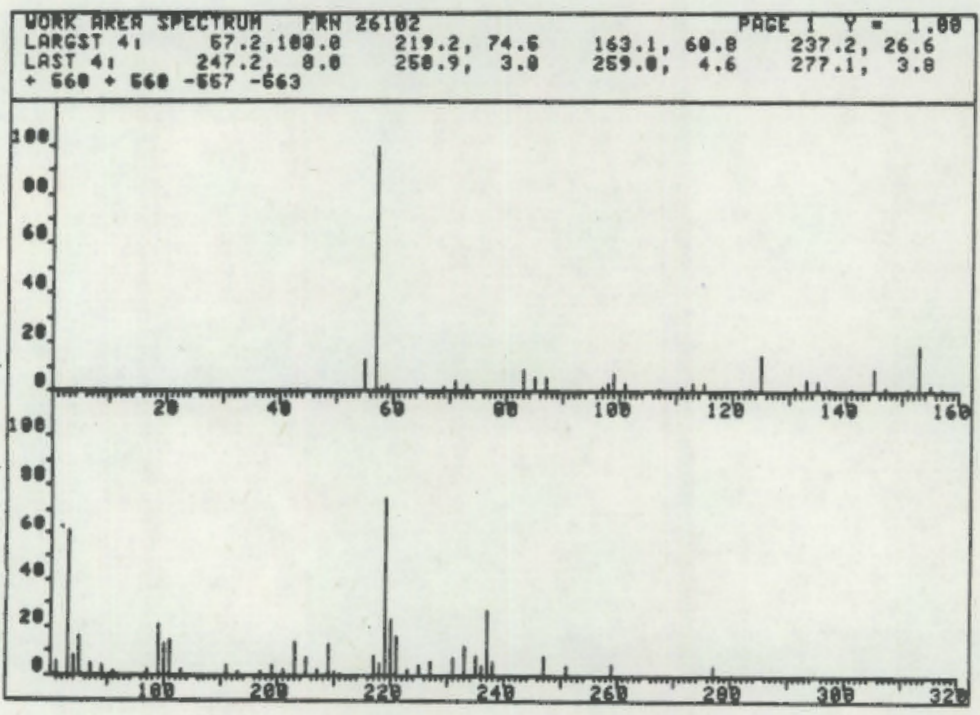

FIGURE C-7. Unknown $M=162, M=178, M=218 . \quad$ RT $=30.5$ ( $M=162$ corresponds to chloronaphthalene) 


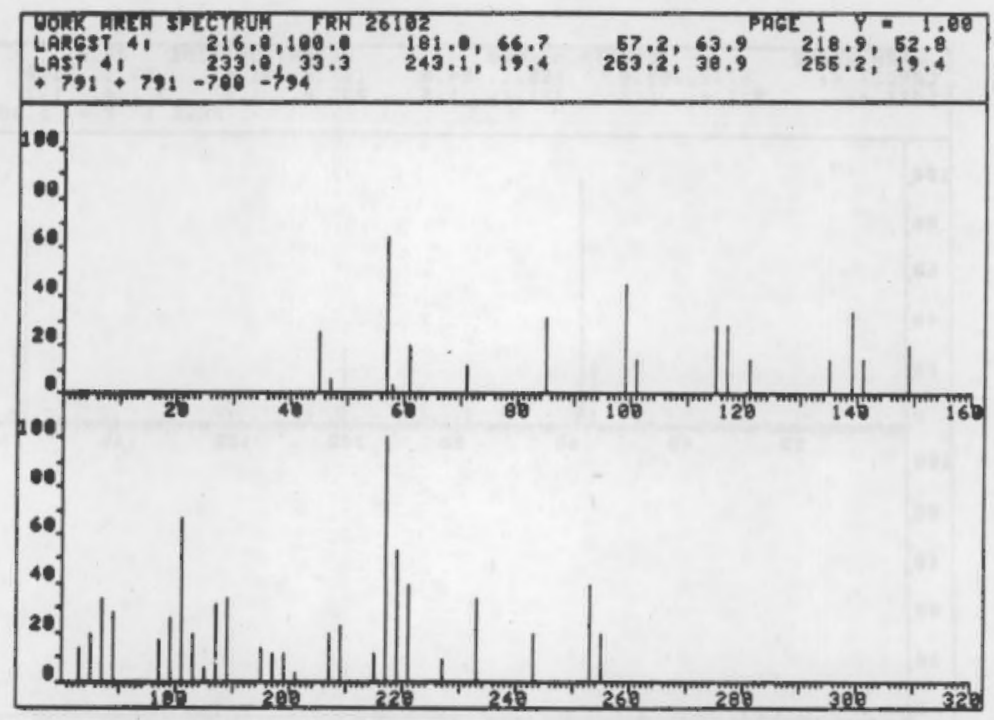

FIGURE C-8. Unknown. RT $=$ 41.8. $M=$ ?. Background--subtracted spectra reveals many fragments which may result from polychlorinated pesticide. Also present in control (unchlorinated) sample. 


\section{APPENDIX D}

GC/MS SPECTRA FROM PHENOL EXTRACTS 
APPENDIX D

\section{GC/MS SPECTRA FROM PHENOL EXTRACTS}

Figures D-1 through D-9 represent data from the Missouri River. Since the phenols were not directly observable in the total ionization chromatograms, they were located by employing the single ion reconstructs corresponding to the molecular ions $(M+1, M+3)$ and the de-acetylated fragment characteristic of acetylated phenols $(\mathrm{M}-42$ or $\mathrm{M}-41)$. These reconstructs, together with the total ionization scans appear in the top portion of Figures D-1 through D-9. The lower part of the figures contain the spectra corresponding to the single ion peaks.

Figures D-10 through D-19 show the data from Cape Fear. This phenol extract was the only sample found to contain sufficient quantities of phenols such that they appeared in the total ionization chromatograms. Figure D-10 shows the chromatogram obtained and identifies the retention times corresponding to the spectra given in Figures $D-11$ through $D-19$. The halogen isotope ratios in the spectra identified the number and type of halogens present. The characteristic ions $M+1, M+2$ and $M-41$ or $M-42$ are given with each spectra. 

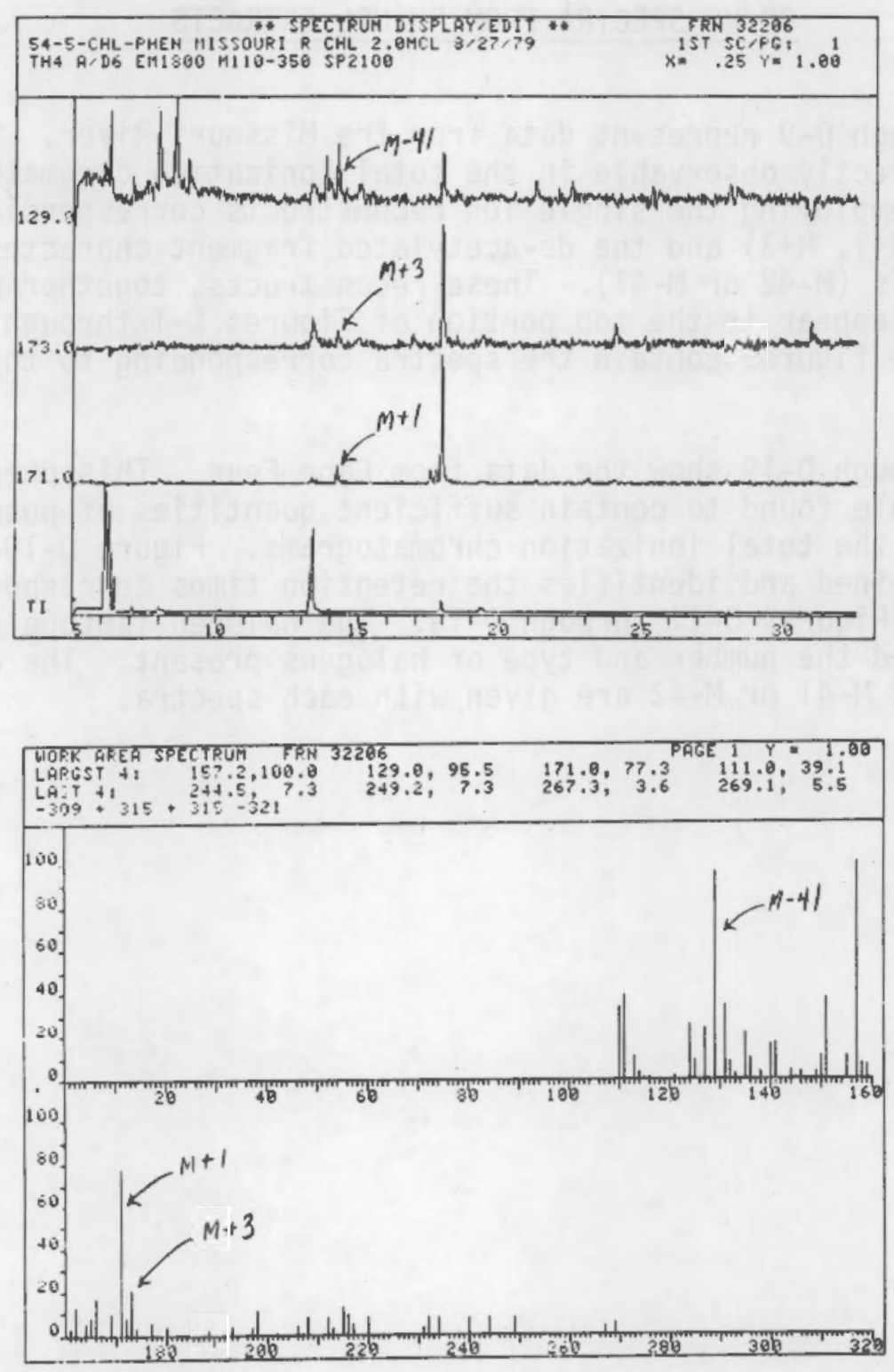

FIGURE D-1. Missouri River, RT $=14.1, M=170$ (chlorophenol) 

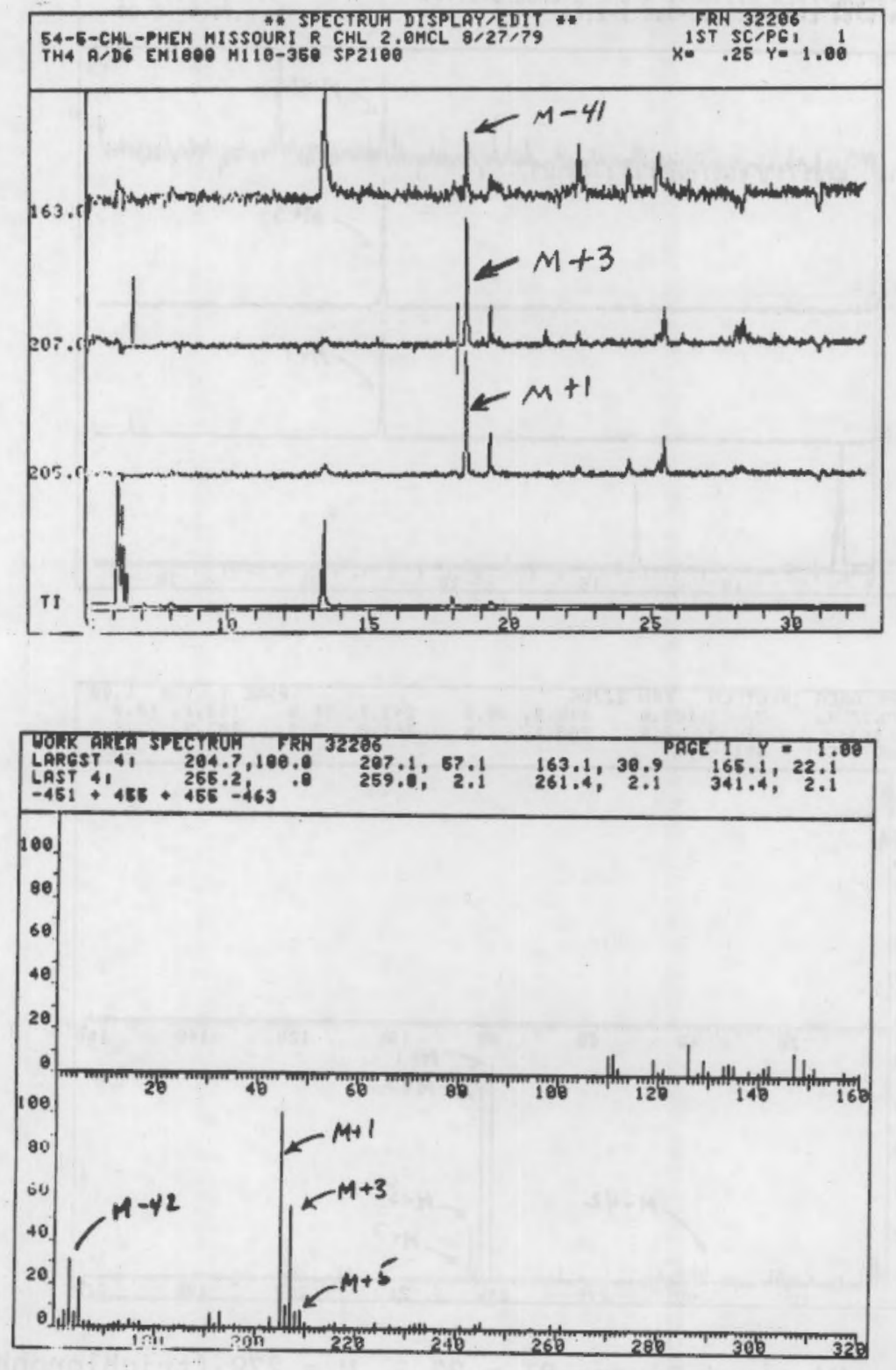

FIGURE D-2. Missouri River, RT $=18.3, M=204$ (dichlorophenol) 

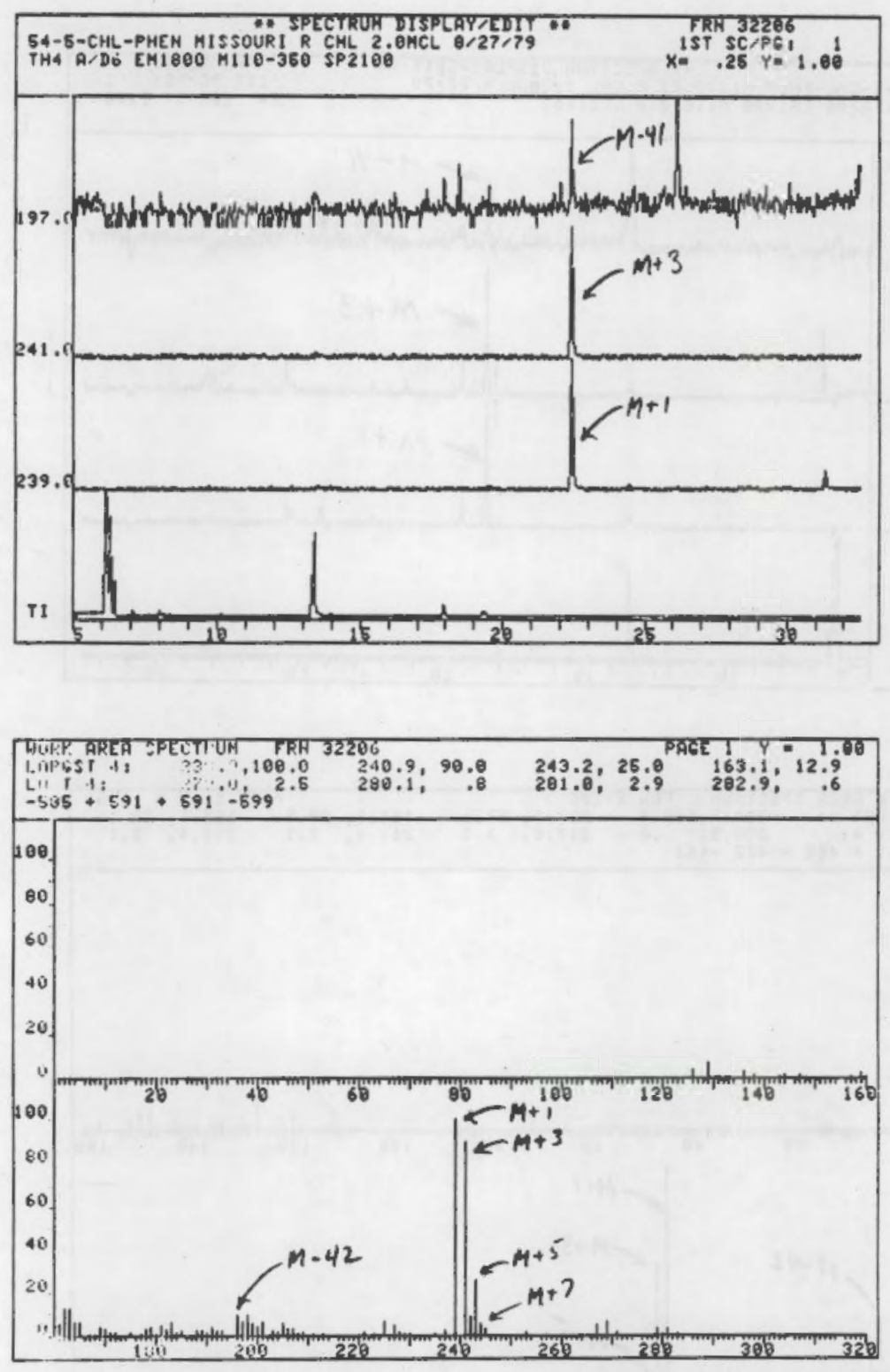

FIGURE D-3. Missouri River, RT $=22.3, M=238$ (trichlorophenol) 

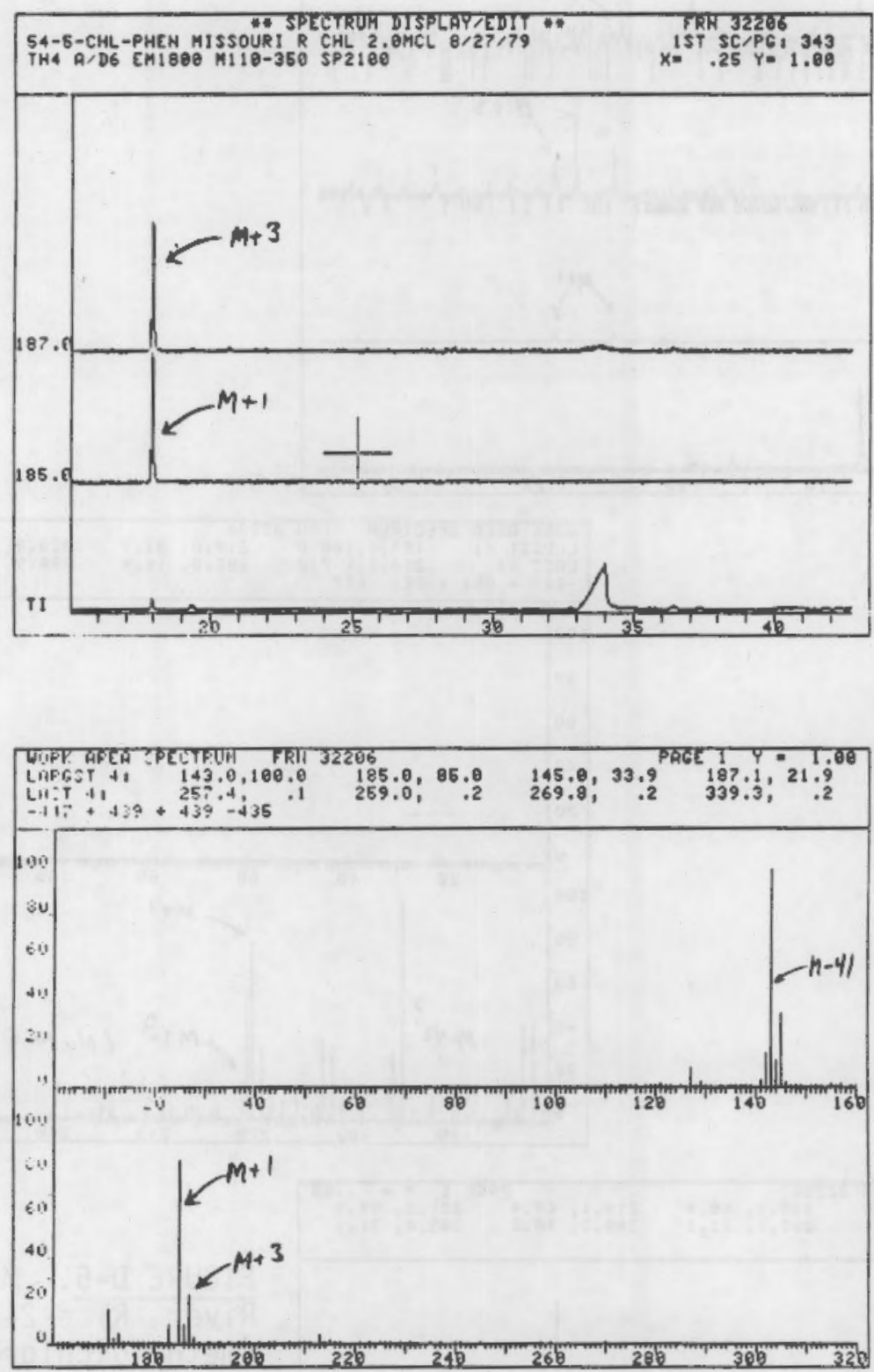

FIGURE D-4. Missouri River, RT $=18.0, M=184$ (methylchlorophenol) 

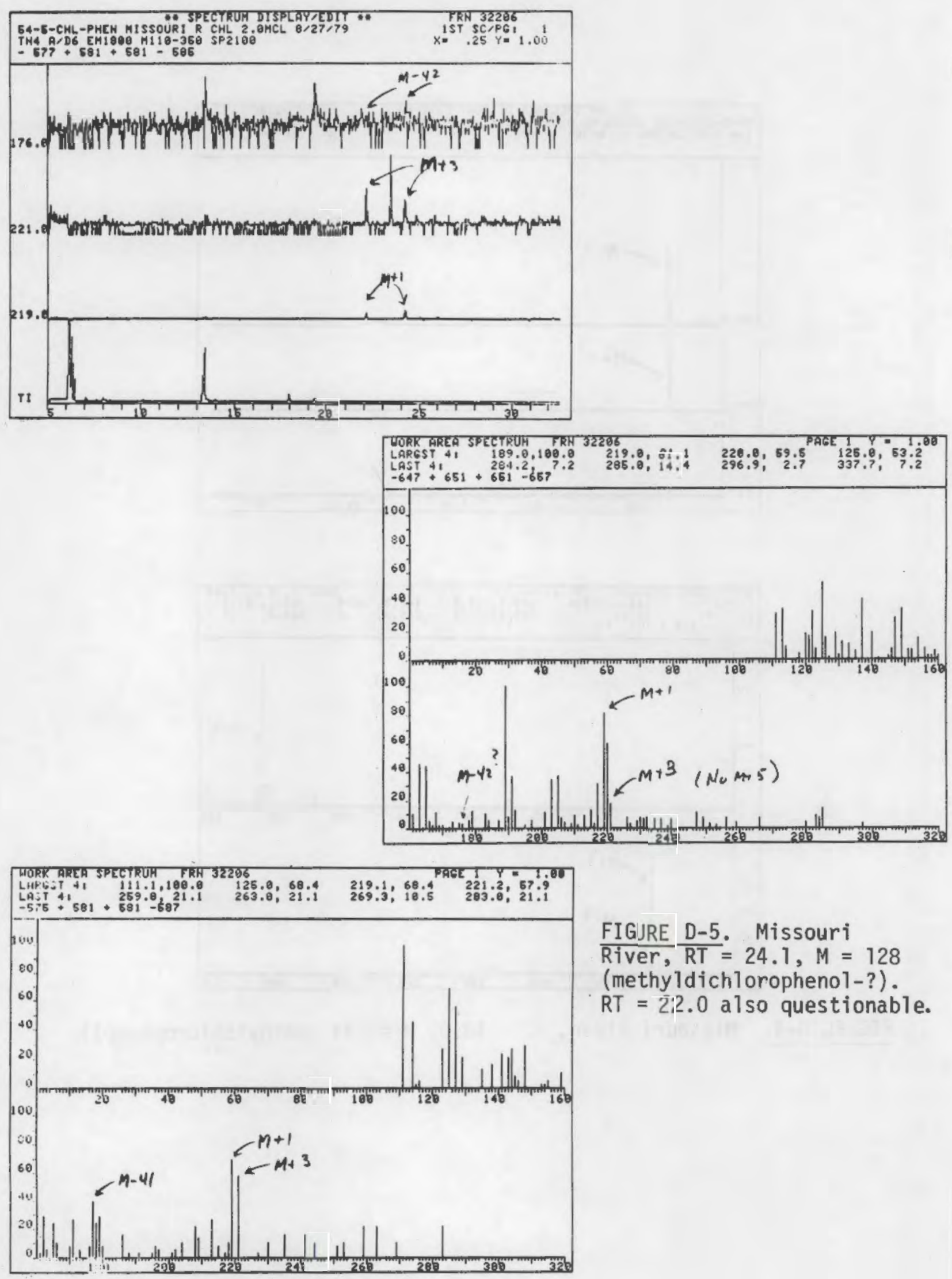

FIGURE D-5. Missouri

River, RT $=24.1, M=128$ (methyldichlorophenol-?). RT $=22.0$ also questionable. 

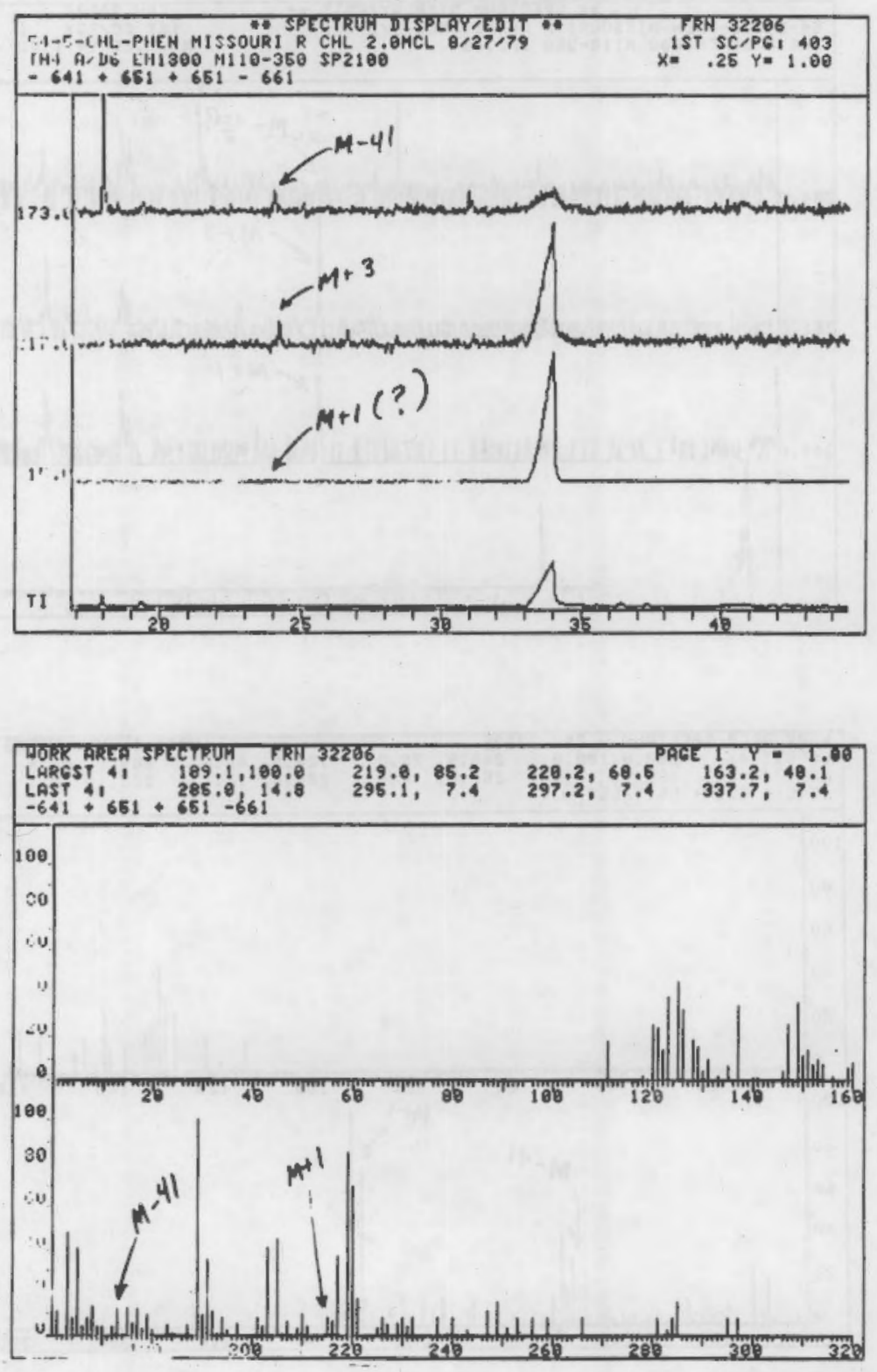

FIGURE D-6. Missouri River, RT $=24.2, M=214$ (bromopheno1 - ?) 

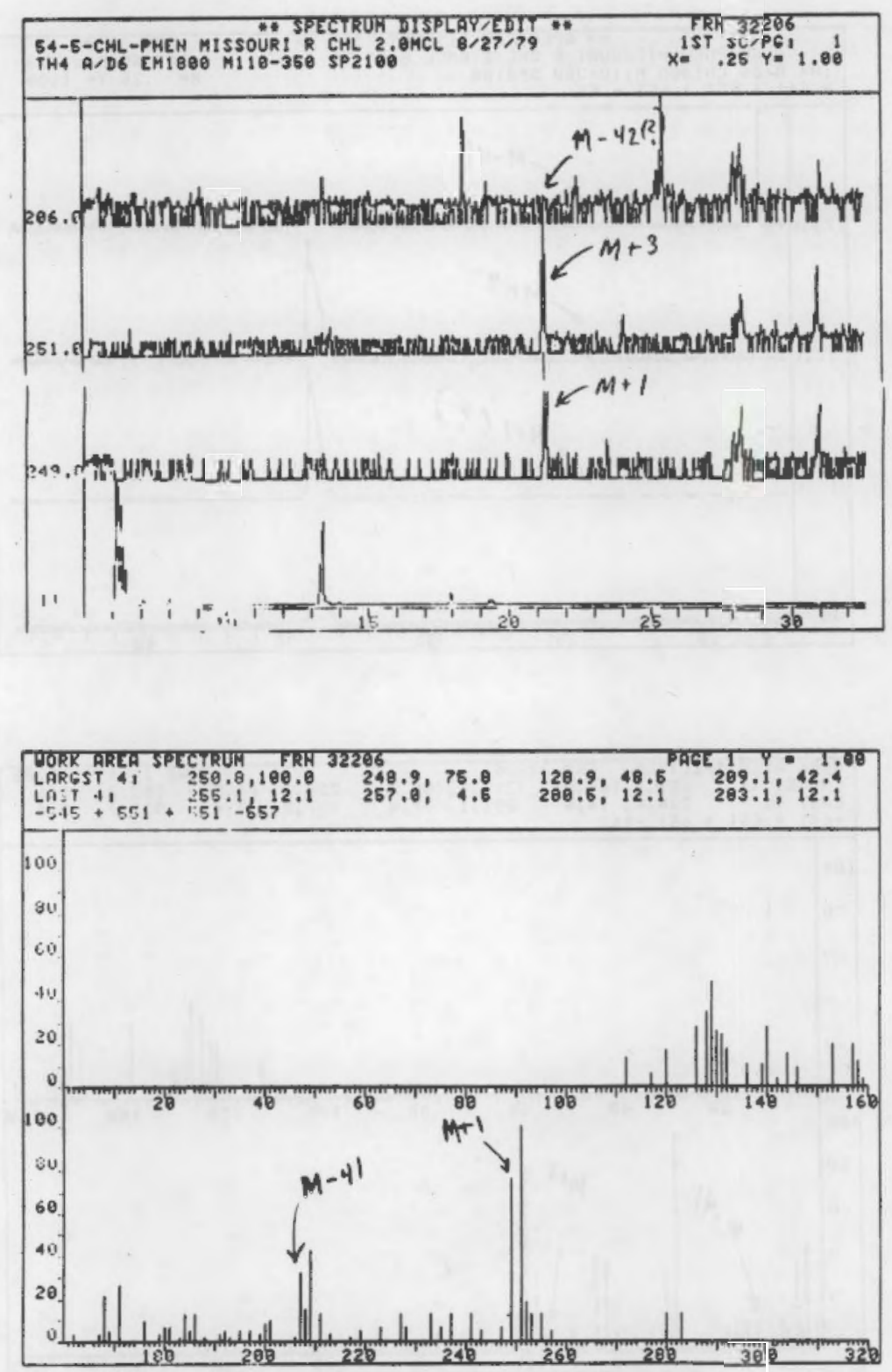

FIGURE D-7. Missouri River, RT $=21.1, M=248$ (chlorobromophenol) 

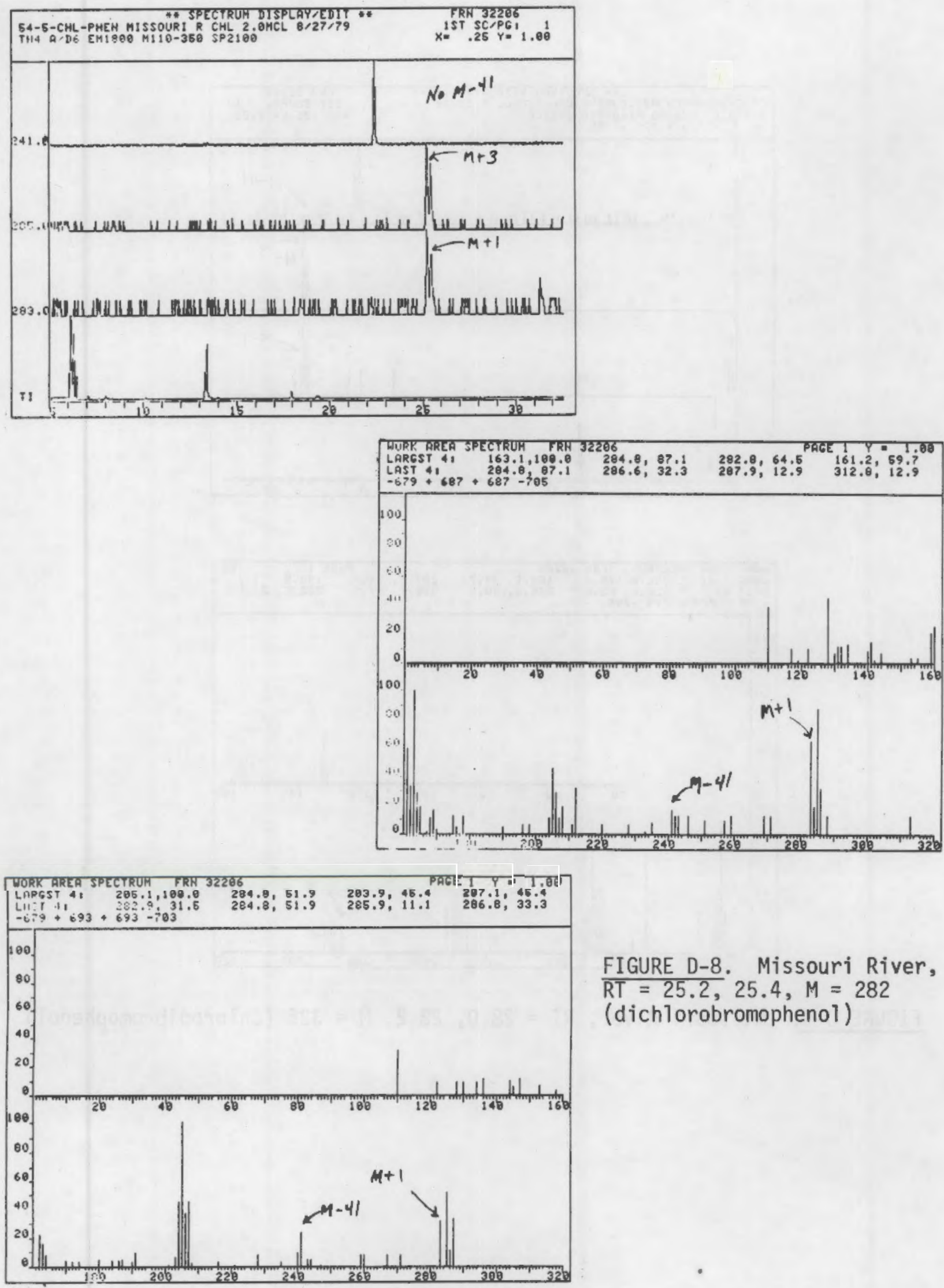

FIGURE D-8. Missouri River, RT $=25.2,25.4, M=282$ (dichlorobromophenol) 

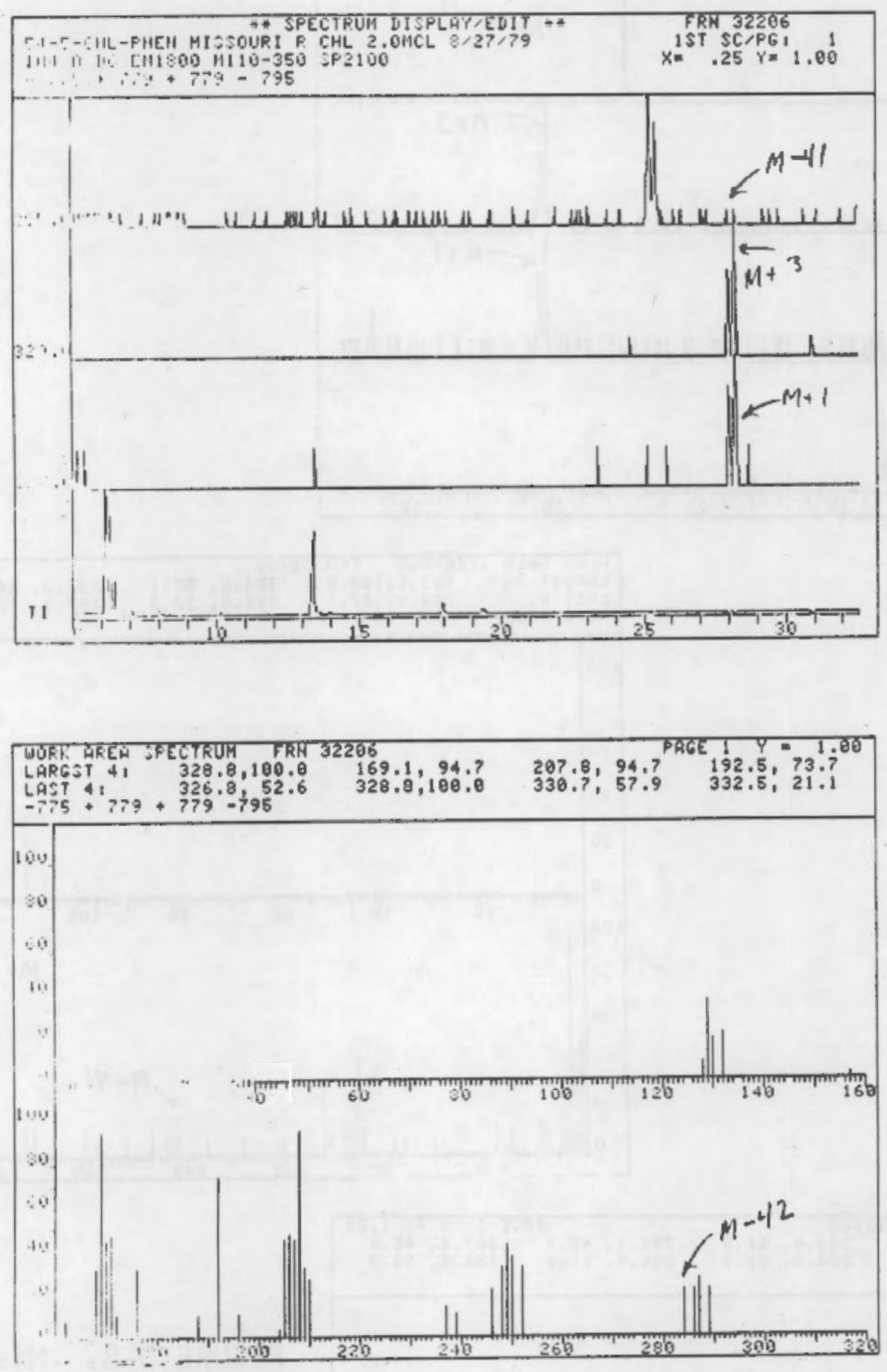

FIGURE 0-9. Missouri River, RT $=28.0,28.2, M=326$ (chlorodibromophenol) 

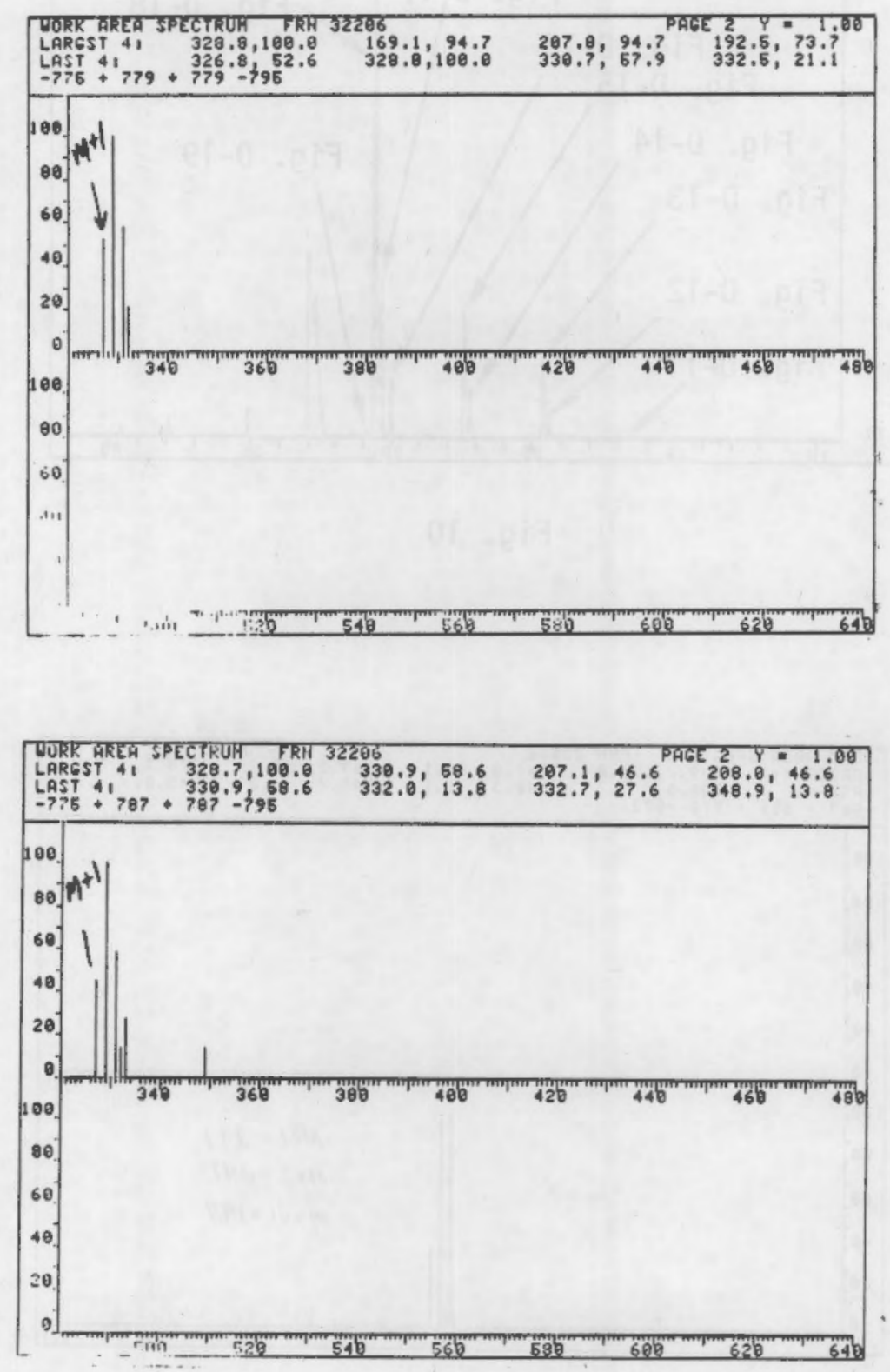

FIGURE D-9. Missouri River, RT $=28.0,28.2, \mathrm{M}=326$ (chlorodibromophenol) 


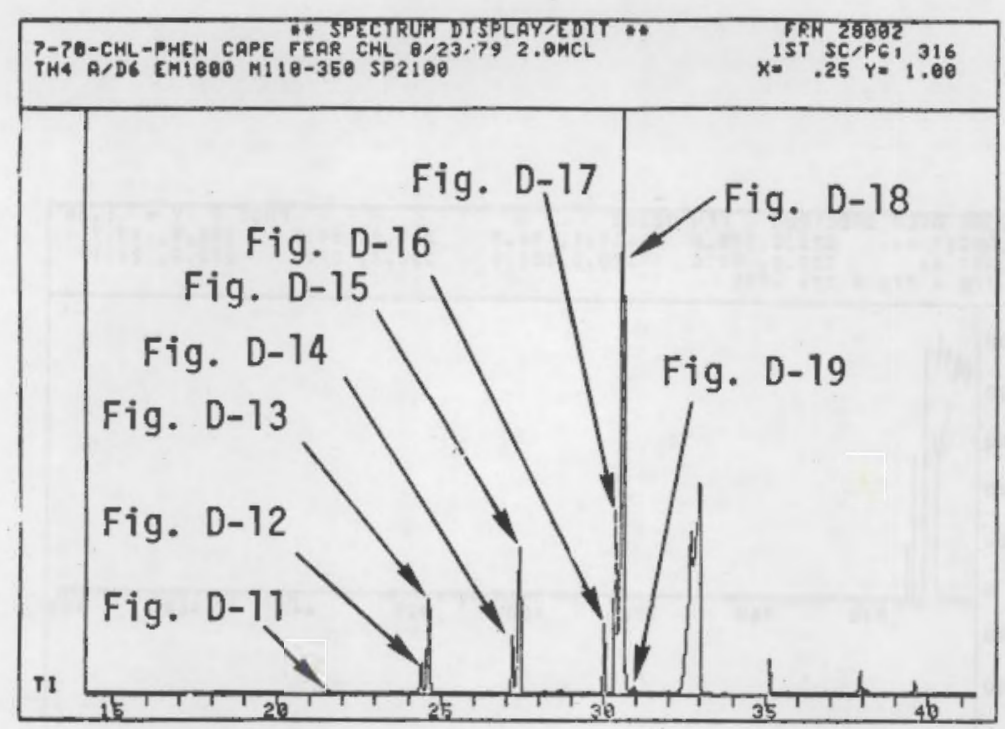

Fig. 10

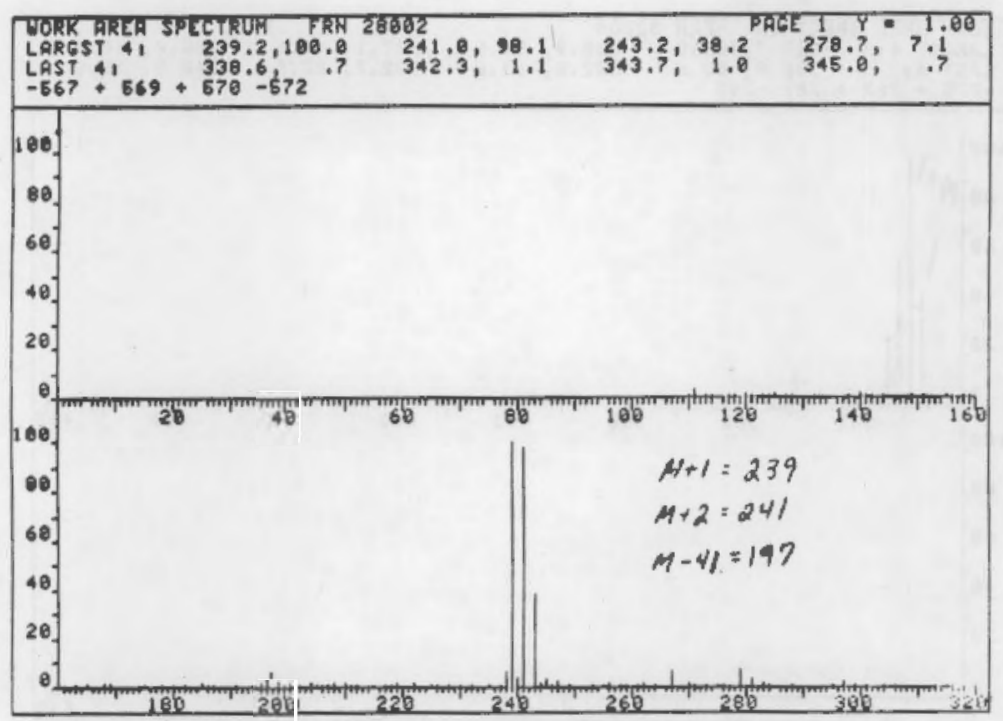

FIGURE D-11. Cape Fear R. CT, RT $=21.5, M=238$ (trichloropheno1) 


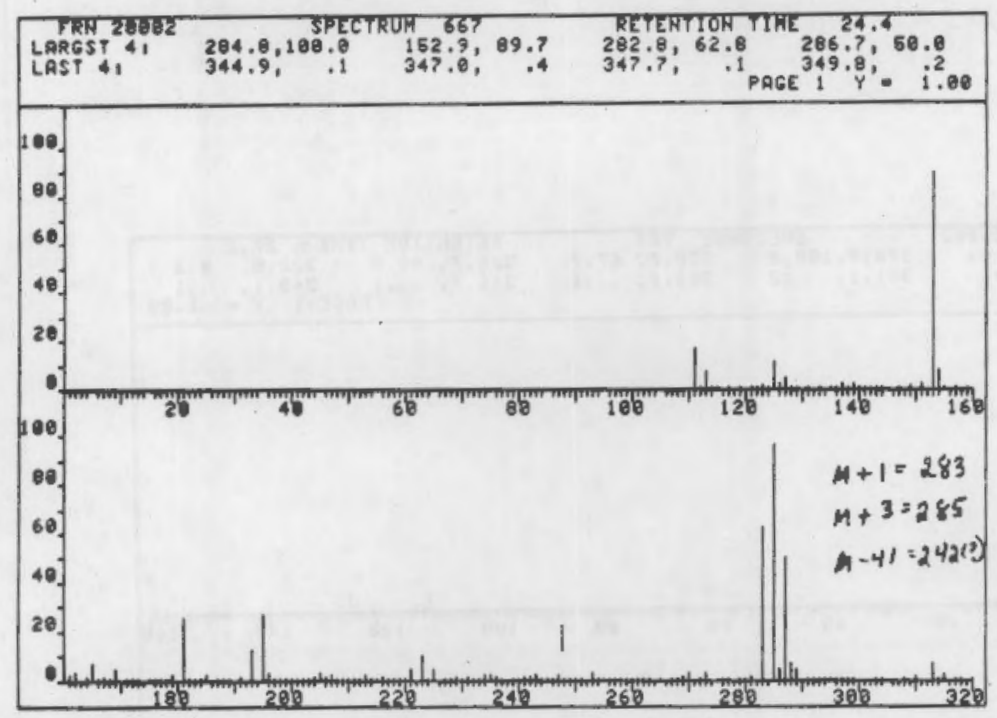

FIGURE D-12. Cape Fear R. CT, RT $=24.4, M=282$ (dich7orobromophenol)

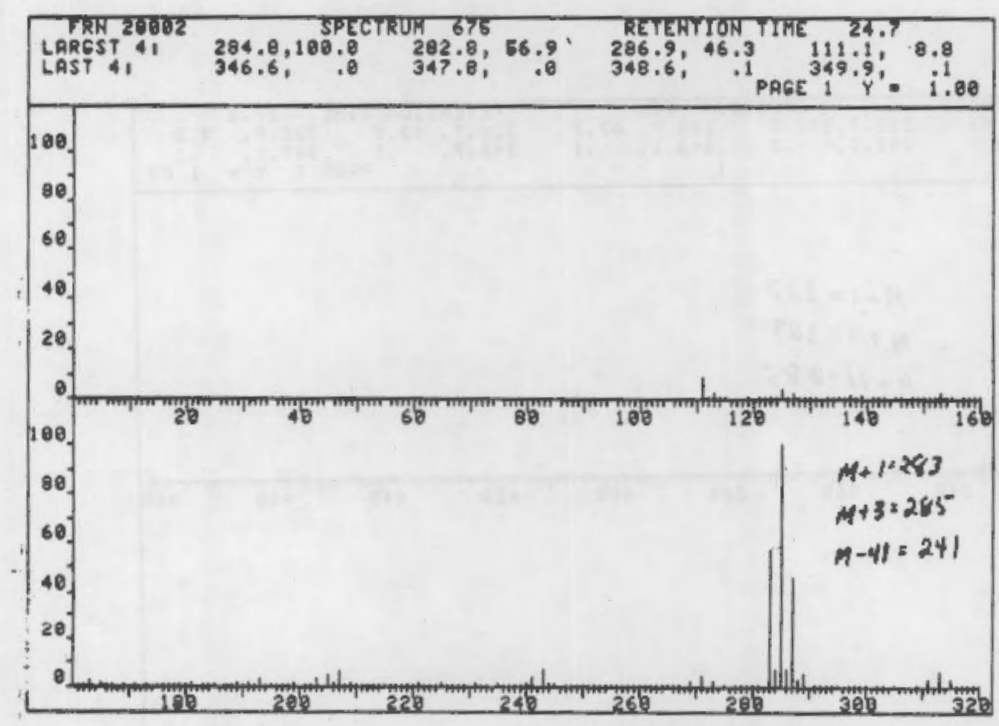

FIGURE D-13. Cape Fear R. CT, RT $=24.7, M=282$ (dichlorobromophenol) 

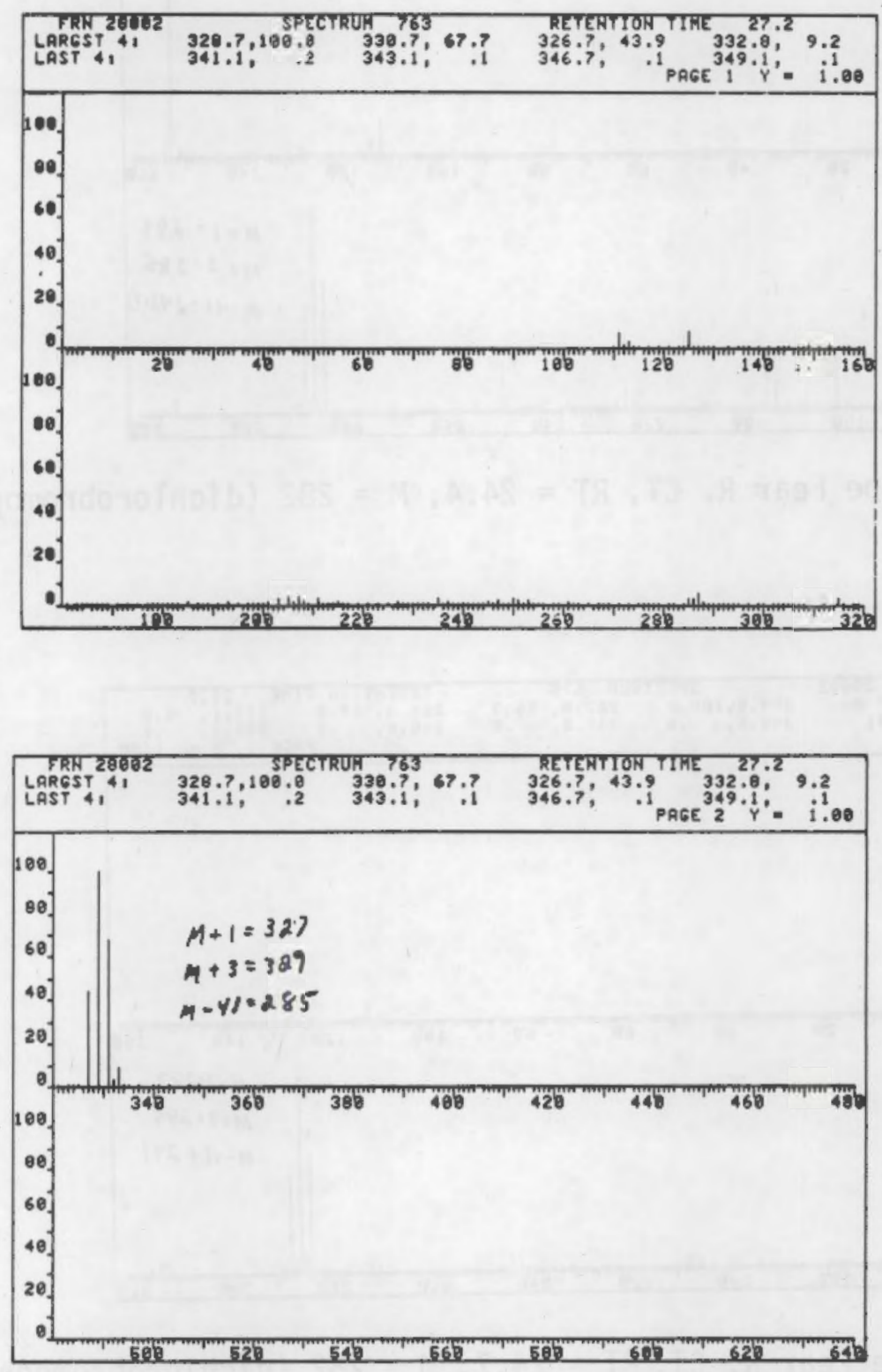

FIGURE D-14. Cape Fear R. CT, RT $=27.2, M=326$ (chlorodibrompheno1) 

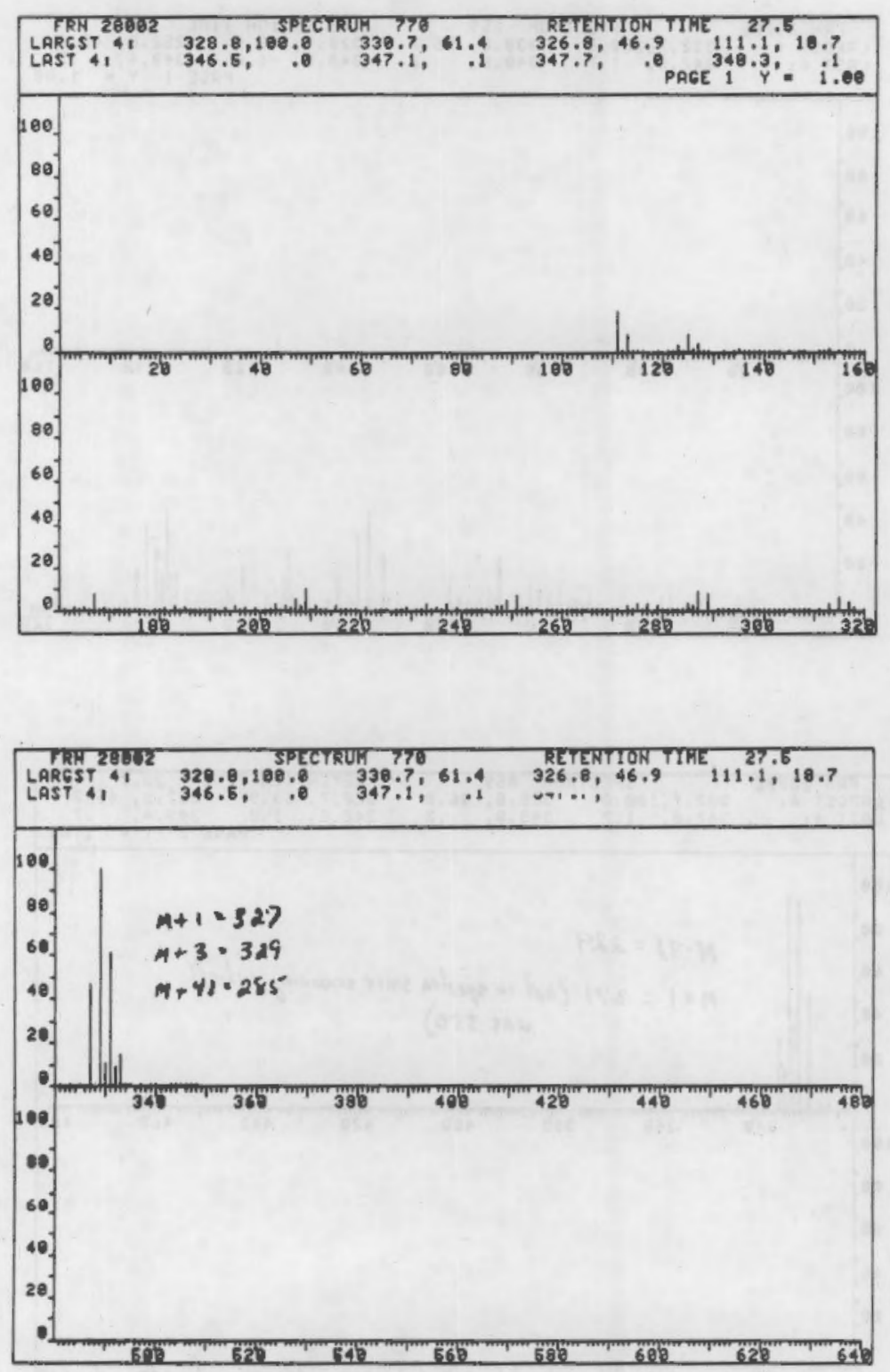

FIGURE D-15. Cape Fear R. CT, RT $=27.5, M=326$ (chlorodibromophenol) 

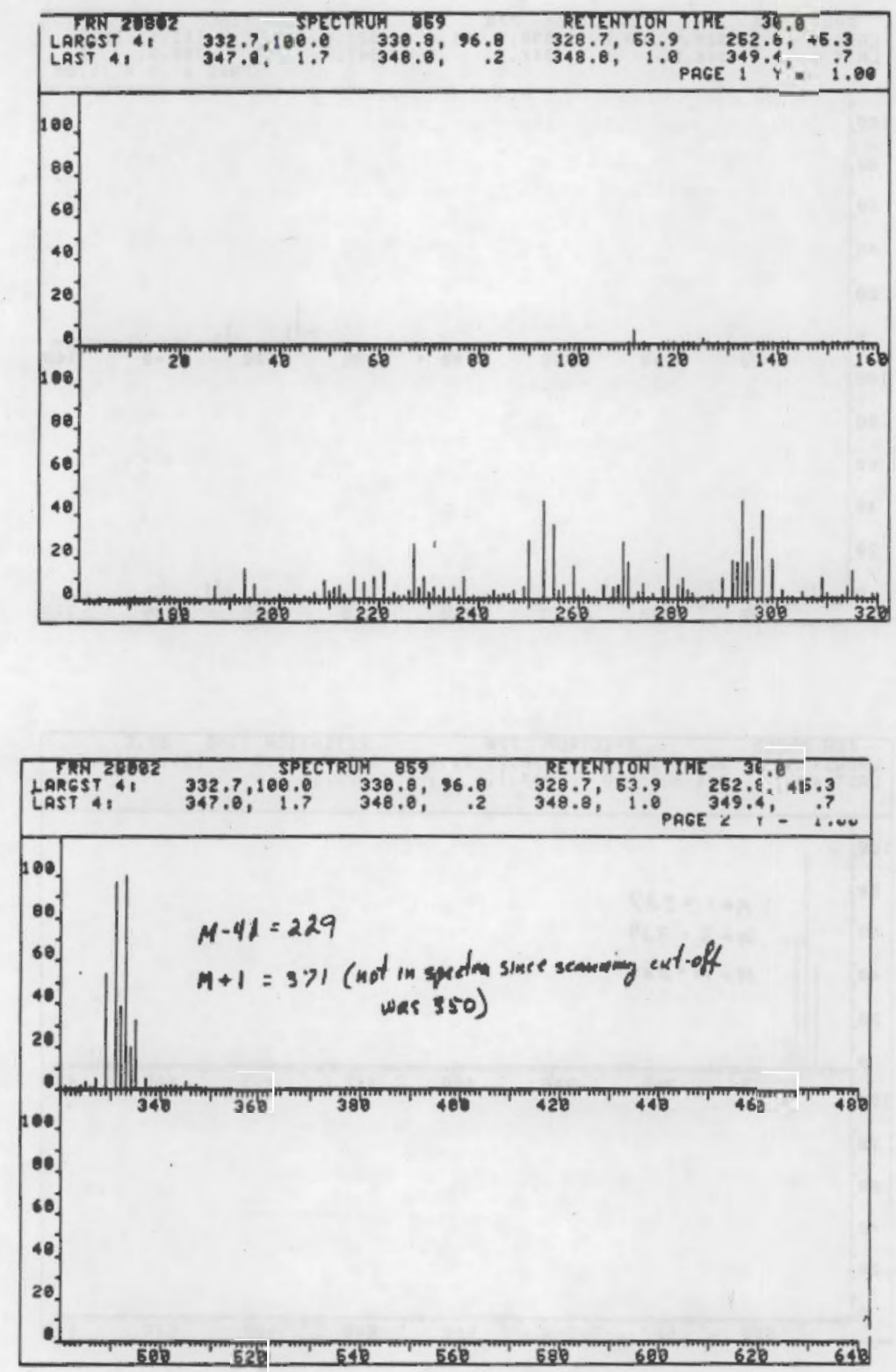

FIGURE D-16. Cape Fear R. CT, RT $=30.0, M=370$ (tribromophenol) 


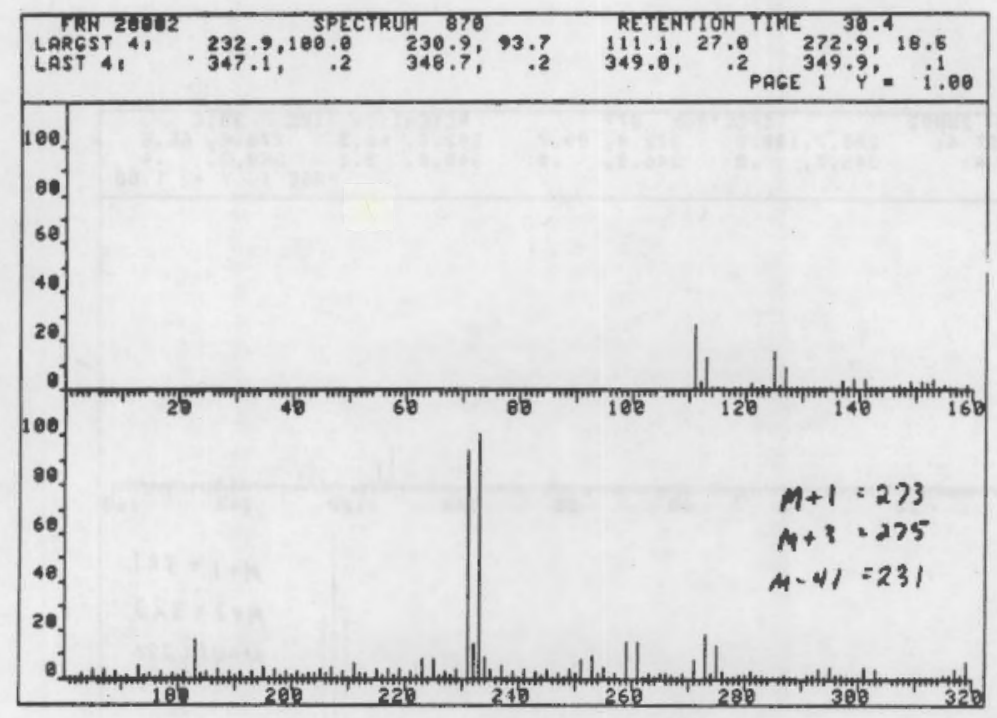

FIGURE D-17. Cape Fear R. CT, Unidentified. RT $=30.4$, $M=272$ (a monobrominated phenol) 

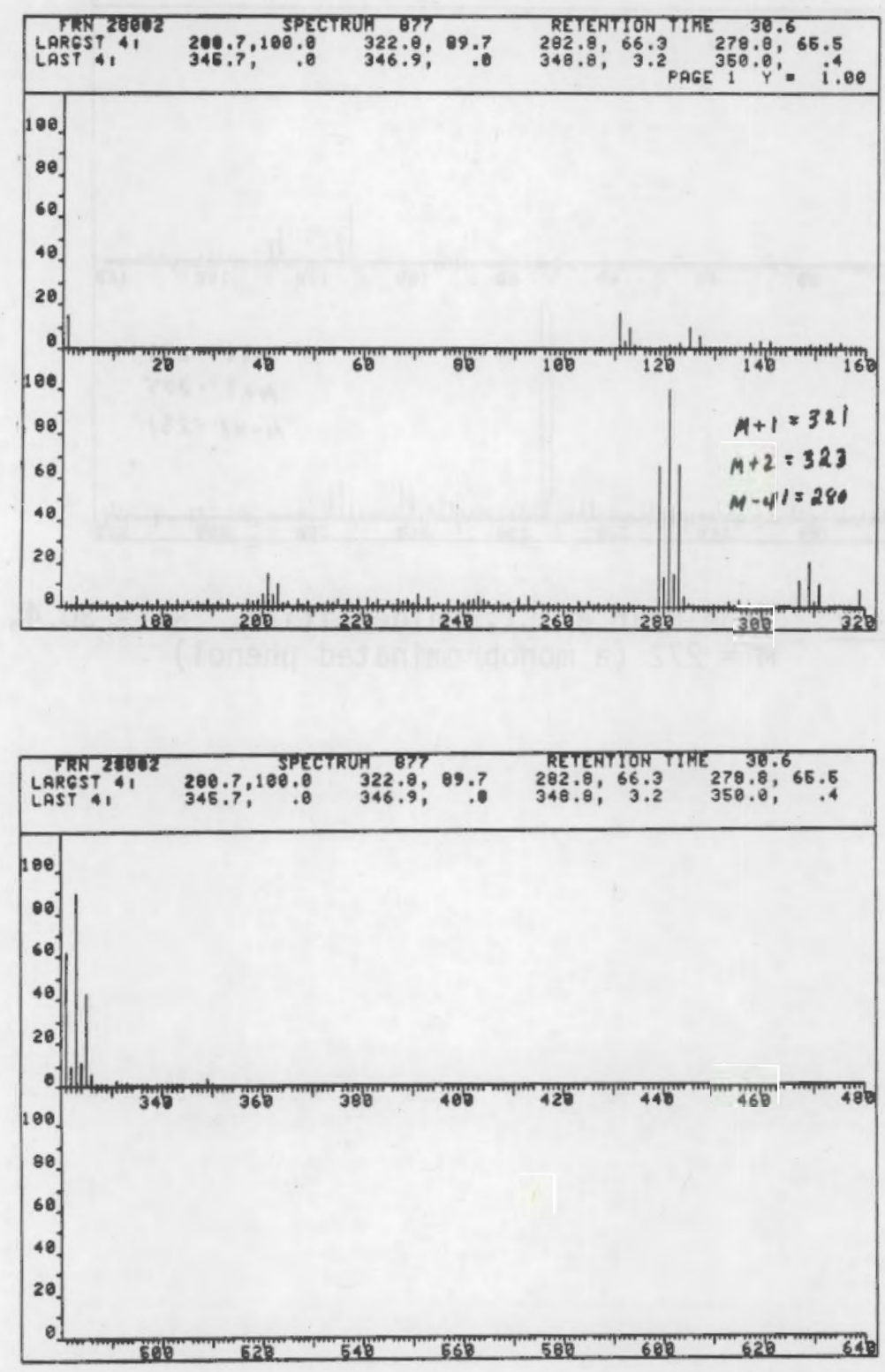

FIGURE D-18. Cape Fear R. CT, RT $=30.6$, M 320 (dimethyldibromopheno1) 

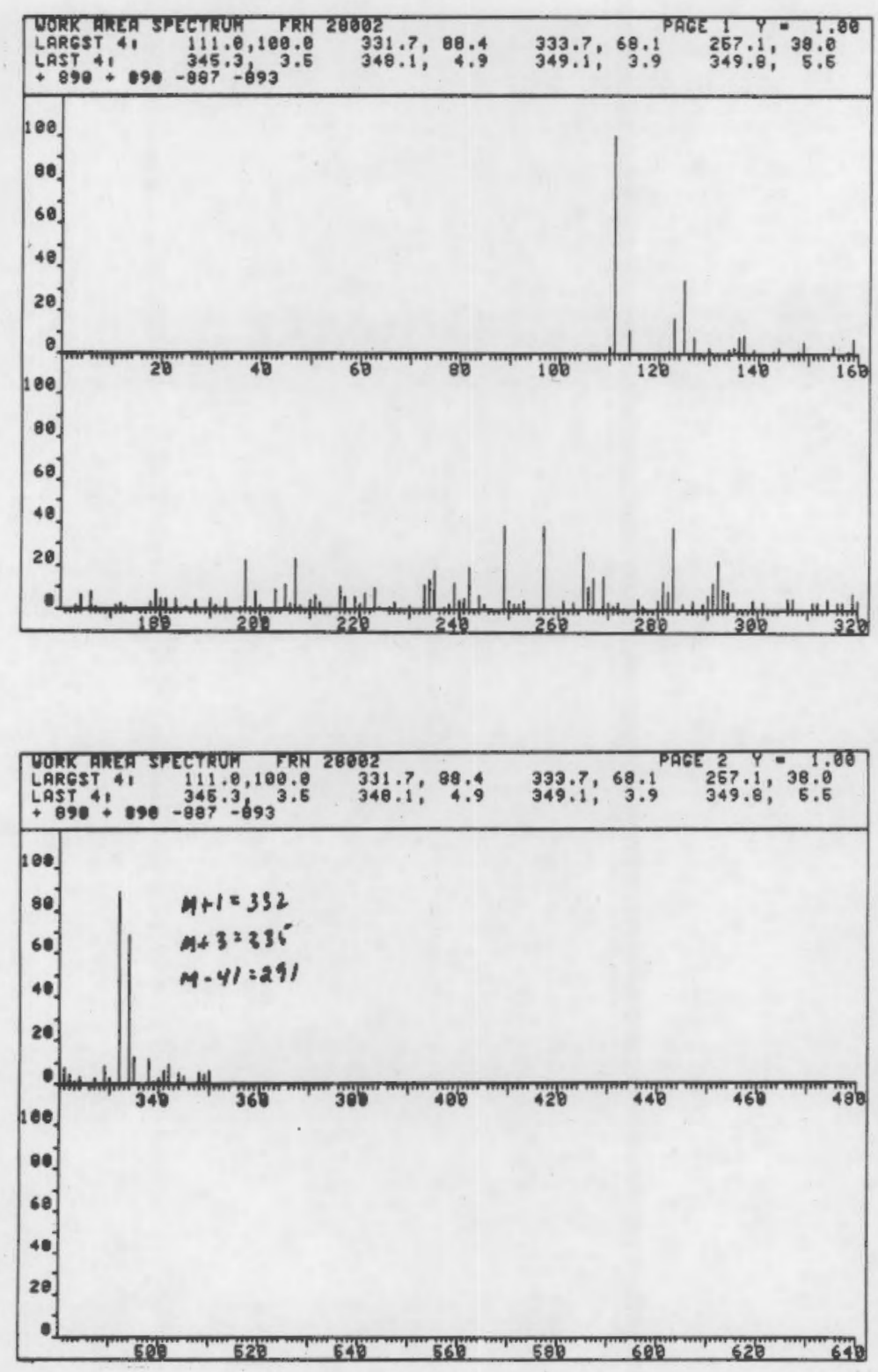

FIGURE D-19. Cape Fear R. CT, Unidentified, RT $=31.0, M=331$ (a monobrominated phenol. Contains nitrogen). 

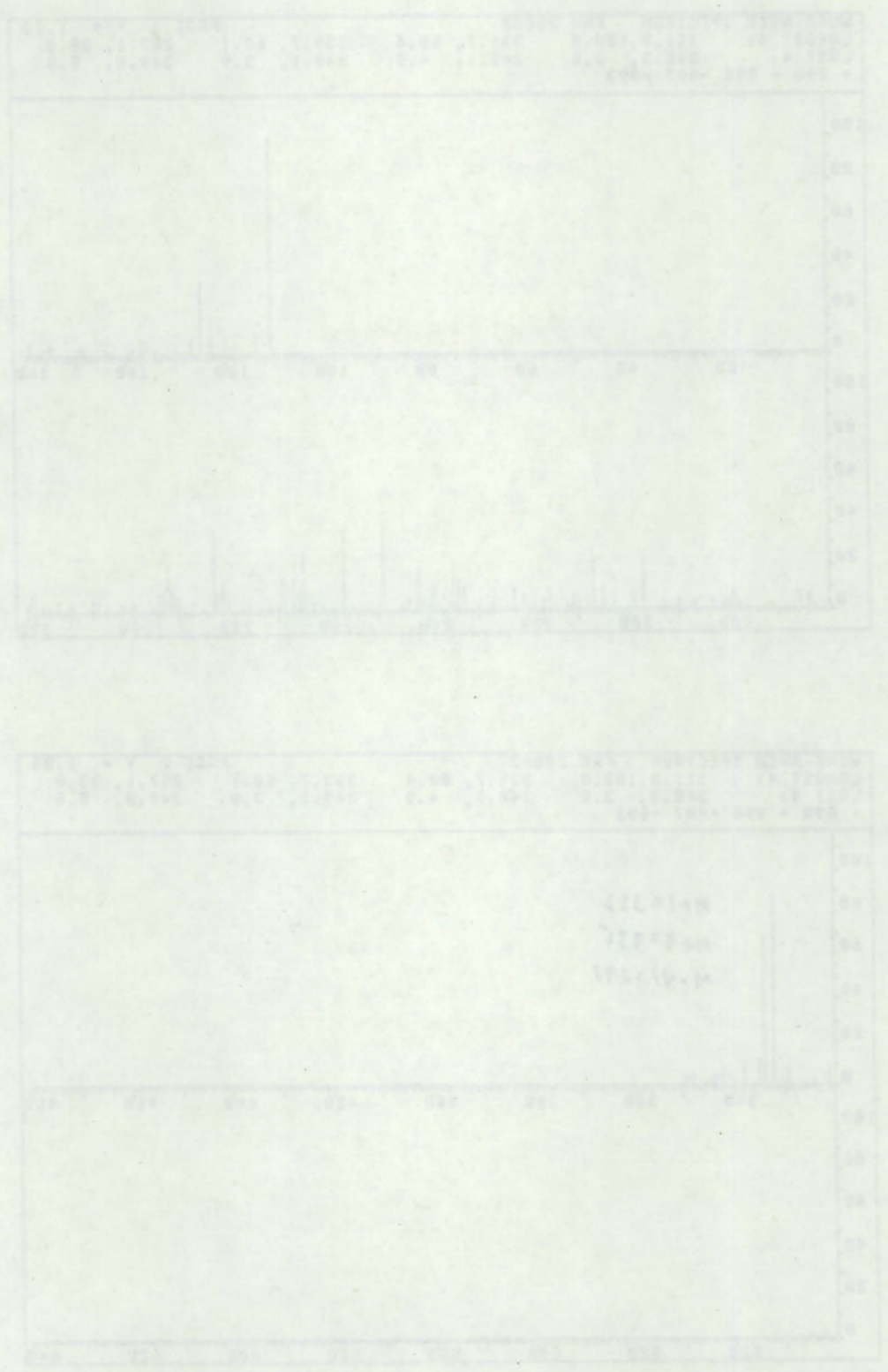
No. of

Copies

OFFSITE

A. A. Churm

DOE Patent Office

9800 S. Cass Avenue

Argonne, IL 60439

10 Dr. Phillip R. Reed

Bob Samworth

John C. Lehr

U.S. Nuclear Regulatory Commission

7915 Eastern Avenue

Silver Springs, MD 20901

226 NRC Division of Technical Information and Document Control

Washington, DC 20555

2 DOE Technical Information Center

D. R. Anderson

2521 N. 40 th, No. 1

Seattle, WA 98103

Dr. Robert Broxton

Electric Power Research Institute

PO Box 10412

Palo Alto, CA 94303

Dr. Dennis T. Burton

Academy of Natural Sciences of Philadelphia

Benedict Estuarine Research Laboratory

Benedict, MD 20612
No. of

Copies

Dr. Will Davis

U.S.E.P.A.

Gulf Breeze Environmental

Research Laboratory

Wadmalaw Island, SC 19487

Dr. R. E. Hillman

W. F. C1app Laboratories

Washington Street, P.0. Box AH

Duxbury, MA 02332

Dr. Donald Johnson

Dept. Environmental Sciences and Engineering

School of Public Health

University of North Carolina

Chapel Hi11, NC 27514

Dr. George R. Helz

Chemistry Dept.

University of Maryland

College Park, MD 20742

Dr. Milton H. Lietzke

P.0. Box X

Oak Ridge National Laboratory

Oak Ridge, TN 37830

Dr. John Lum

U.S.E.P.A.

401 M Street S.W.

WH552

Washington, DC 20460

Or. Roy Nakatani

Dr. Quentin J. Stober

FRI WH-10

University of Washington

Seattle, WA 98195 
No. of

Copies

Dr. Thomas 0 . Thatcher

Rt 2 Box 113

Sequim, WA 98382

F. C. Tone

Florida Marine Research Facility

Daytona Beach, FL

Ronald L. Raschke

U.S. EPA

S.E. Water Laboratory

Bailey Road

Athens, GA 30601
No. of

Copies

\section{ONSITE}

50 Pacific Northwest Laboratory

RM Bean (32)

CI Gibson

KE Harding (4)

DC Mann

TL Page

RG Riley

RE Schirmer

NM Sherer

RE Wildung

Publishing Coordination (2)

Technical Information (5) 



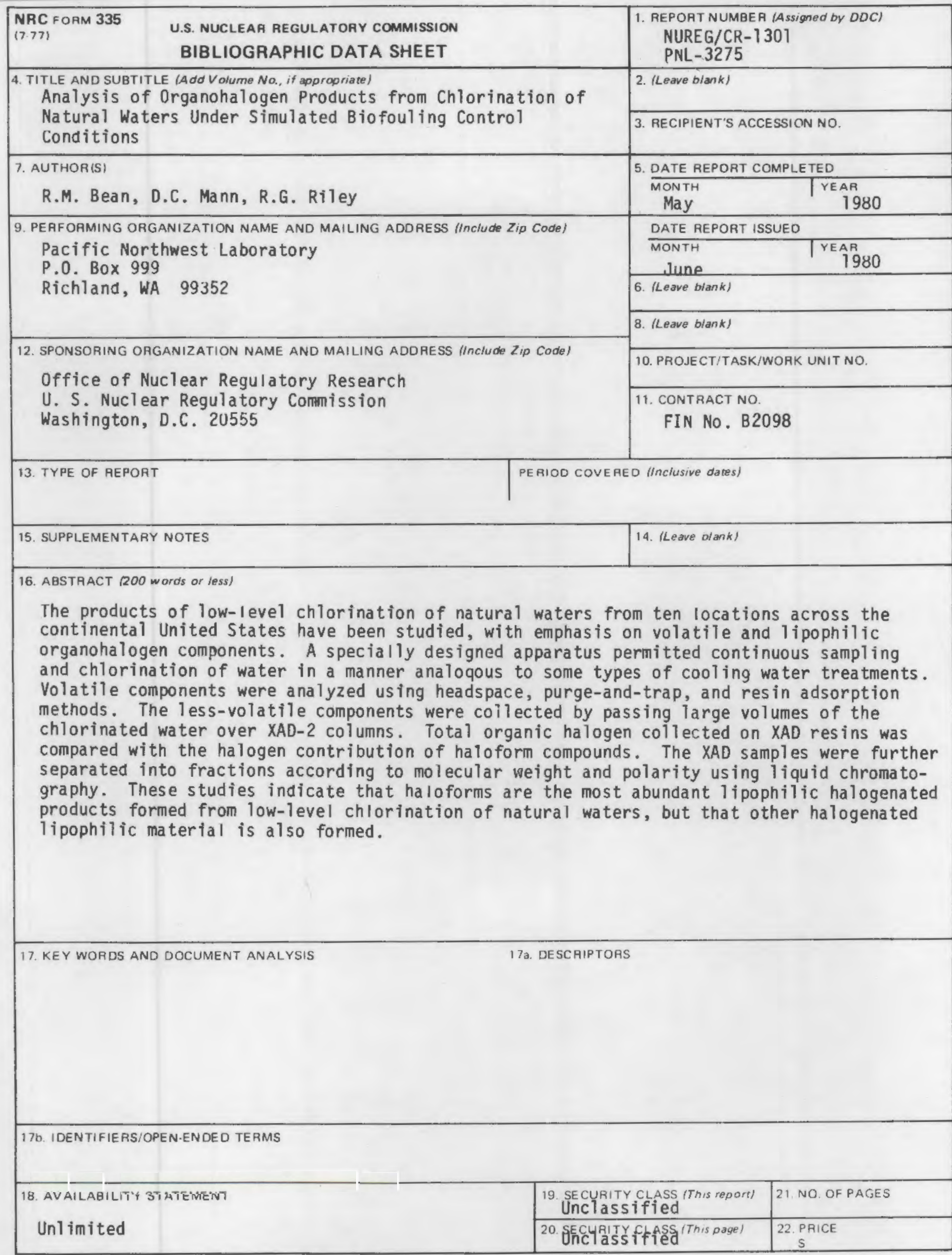


